\title{
Carbon Issues Task Force Report for the Idaho Strategic Energy Alliance
}

October 2010

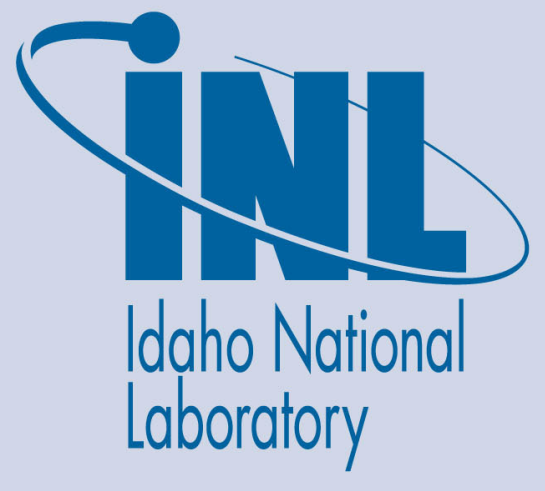

The INL is a U.S. Department of Energy National Laboratory operated by Battelle Energy Alliance 
INL/EXT-11-21252

\title{
Carbon Issues Task Force Report for the Idaho Strategic Energy Alliance
}

October 2010

\author{
Idaho National Laboratory \\ Idaho Falls, Idaho 83415
}

http://www.inl.gov

Prepared for the

U.S. Department of Energy

Under DOE Idaho Operations Office

Contract DE-AC07-05ID14517 
October 20, 2010

Subject: Transmittal to ISEA Council of the Carbon Issues Task Force Report

Dear Council Members:

The Board of Directors (Board) of the Idaho Strategic Energy Alliance (ISEA) recognizes and thanks the Carbon Issues Task Force for their preparation of this report. The Task Force is comprised of volunteer experts in the areas of geosciences, policy and strategy development, environmental protection, agriculture, forestry, carbon sequestration, climate change, utilities, universities, and state and federal agencies who have worked together in the interest of Idaho citizens to suggest actions that will help develop Idaho energy resources.

The Carbon Issues Task Force has the responsibility to evaluate emissions reduction and carbon offset credit options, geologic carbon sequestration and carbon capture, terrestrial carbon sequestration on forest lands, and terrestrial carbon sequestration on agricultural lands. They have worked diligently to identify ways in which Idaho can position itself to benefit from potential carbon-related federal legislation, including identifying opportunities for Idaho to engage in carbon sequestration efforts, barriers to development of these options, and ways in which these barriers can be overcome. These are the experts to which we will turn when faced with federal greenhouse gas-related legislation and how we should best react to protect and provide for Idaho's interests. Note that the conclusions and recommended options in this report are not intended to be exhaustive, but rather form a starting point for an informed dialogue regarding the way-forward in developing Idaho energy resources.

It is the ISEA Board's responsibility to evaluate, given available data, recommended options and to articulate to you and other Idaho policy leaders and lawmakers our opinion regarding whether the potential benefits and costs associated with the suggested options create a favorable opportunity for Idaho citizens. Our initial review comments are summarized in this transmittal. The Board believes that a complete assessment of individual reports cannot be made, however, until all of the Task Force reports and options have been evaluated. In this respect, both this report and the Board's comments should be viewed as "living documents" that will be updated as significant new information and/or perspectives develop.

\section{Summary of Task Force Recommendations}

The Carbon Issues Task Force provided over forty recommendations in four broad areas: Emissions Reductions and Carbon Offsets, Geologic Sequestration, Forestry, and Agriculture. The ISEA Board's assessment of these recommendations was primarily supportive. Parties identified as responsible for implementation of the recommendations is noted in italicized parentheses:

\section{Emissions Reduction / Carbon Offset Credits}

1. Idaho should continue to participate as an observer in the Western Climate Initiative. As one Board member commented, "Given the uncertainties surrounding federal climate change legislation, Idaho should continue its current role as observer until such time as devoting more resources to this issue is warranted." (Idaho Carbon Sequestration Advisory Committee a.k.a. ICSAC) 
2. Idaho should continue to participate in The Climate Registry (TCR), as it allows the state to understand what is being proposed and keep abreast of the developing direction so it can be better positioned to identify opportunities and avoid negative consequences. (DEQ)

3. Encourage more Idaho companies to sign up with TCR. As one Board member noted, "Now is the time for Idaho companies to register with TCR so that they are not caught unprepared when federal climate change legislation is enacted." (DEQ)

4. Create a closer link between the DEQ and the OER as it relates to climate change and carbon regulation, as this provides increased staff expertise in this important area. (DEQ and OER)

5. Improve upon the State's current GHG Emissions Inventory. Some strongly believe that this will help prepare Idaho for compliance with federal legislation, but others were concerned about the potential cost of this effort. (DEQ)

6. Track what other states are doing in emissions reductions and tracking programs to help identify options for Idaho. Again, there were some concerns about the cost of such an effort. (DEQ)

7. Coordinate an effort to identify Idaho opportunities to take advantage of potential offsets and how our industries could benefit, although it was noted that some entities are not supportive of the use of offsets in lieu of actual emissions reductions. (DEQ)

\section{Geologic carbon sequestration \& Carbon Capture}

8. Develop a regulatory framework for geologic carbon capture and sequestration (CCS). Most believe that this is critically important if Idaho intends to be in a position to permit applications for geologic sequestration of atmospheric carbon. (ICSAC)

9. Lead education \& outreach to allow for a broad-based response to the educational needs in the state with respect to policy and CCS issues. This would allow for a broad-based response to the educational needs in the state with respect to policy and CCS issues. (CAES)

10. Lead efforts to assess federal cap-and-trade effects on Idaho. It was pointed out that the experts that participate on this task force are uniquely qualified for this activity and could easily carry it out, the only problem being that most of the task force members serve on a volunteer basis with their time already at a premium and that cap-and-trade legislation is currently a "moving target." (ISEA Carbon Issues Task Force a.k.a. CIT)

11. Collaborate with states that export energy to Idaho to determine the impact CCS activities will have on Idaho's economy. It is critical to note that much of Idaho's carbon-related energy comes from neighboring states that will be passing their costs on to Idaho consumers. (CIT)

12. Recommend to Idaho legislature that they charge the Idaho Geological Survey with determining Idaho's CCS potential. This recommendation received support because people believe that the state would gain valuable information regarding the deep geologic terrains contained within its borders. Additionally, it would provide an avenue to evaluate the geothermal potential of these portions of the state. However, it could be expensive to implement. (ISEA)

13. Engage industry representatives to define key technical issues limiting unconventional CCS. This recommendation was supported. (ICSAC)

14. Coordinate relevant research activities. (CAES) 
Terrestrial carbon sequestration on forest lands

15. Resolve whether Idaho's forests are a net source of emissions or a net sink for atmospheric carbon. This recommendation was supported by the some members of the Board with recognition of several benefits including providing leverage to pressure the US Forest Service to allow more intensive management on national forest lands to avoid catastrophic wildfires, which are the major source of carbon in forests, as well as identify opportunities to improve forest conditions and renewable energy feedstocks. (DEQ)

16. Develop GHG inventory protocol that includes wilderness areas and is sensitive to annual change in wildfire extent. Again, approved by a majority with the argument that the verifiable measurement of both wilderness areas and wildfire impacts is critical to establishing where Idaho's carbon footprint and sequestration potential stand. (DEQ)

17. Support carbon credits for a full range of forestry offset opportunities, including bioenergy. (DEQ, CAES Energy Policy Institute)

18. Develop quantitative models of forest carbon response $\&$ identify carbon best management practices. (DEQ, IDL, ISCC)

19. Work to increase U.S. Forest Service budget for restoration-based reduction of hazardous fuels to reduce wildfire hazards, improve habitat, increase bioenergy feedstock supply, and redirects slash disposal resulting in fewer open burning emissions. As one Board member put it, "Any additional management of national forest lands is a positive step forward for our state." (Idaho's Congressional Representatives)

20. Provide outreach efforts to develop support for active forest management as this will generate support for active forest management of national forests and increase knowledge of the benefits of managing forests to sequester carbon and provide bioenergy feedstocks. (Idaho Dept. of Lands, UI Cooperative Extension)

\section{Terrestrial carbon sequestration on agricultural lands}

21. Proactively track potential national Cap and Trade legislation and other carbon-related regulatory legislation and policies. This is widely supported to help Idaho stay informed and be aware of future opportunities that present themselves. (ICSAC)

22. Accelerate information and education efforts, especially for the Legislature. This was supported for its perceived value in providing baseline information to the state legislators and land managers regarding how to implement agricultural or forestry-based carbon storage. (ICSAC \& Task Force)

23. Continue pursuing agricultural pilot projects within the voluntary carbon trading market and prepare for integration with future national offset processes, regulations, and/or guideline. This was supported for helping Idaho position itself to take advantage of opportunities as well as potentially provide additional revenue to Idaho's agriculture community. (Idaho Soil Conservation Commission and Idaho's 51 Conservation Districts)

24. Continue working with Pacific Northwest Direct Seed Association (PNDSA), $U$ of I, and WSU in developing carbon sequestration field data on cropland, field-expedient carbon flux measuring tools, and protocols to strengthen this validation process. Widely supported. Agriculture capture of carbon is still the "low hanging fruit" with low adoption cost and relatively high direct and ancillary payback, the characterization of field data relative to Idaho's agriculture carbon storage potential would facilitate landowner adoption options. (ICSAC and the Soil Conservation Commission) 
25. Define roles \& responsibilities of involved state and federal agencies and strengthen communication links between them. Common goals \& objectives should be established through MOUs and/or working agreements. The potential for integrating and targeting funding programs and technical resources needs to be evaluated. Widely supported, as a better definition of the responsibilities of these two groups would be beneficial to their ultimate success. (ICSAC)

26. Continue pursuing a "Designated Cropping Region" for Idaho from the Chicago Climate Exchange and pursue potential participation with the Green Exchange, New York Mercantile Exchange \& other entities. (ICSAC)

27. Pursue funding for developing technologies for reducing GHGs from the dairy / livestock sector. (ICSAC)

28. Pursue funding to evaluate the relative economic competitiveness of possible technologies to reduce emissions \& increase sequestration of carbon. This suffered mixed reviews due to its potential to help us prepare to take advantage of opportunities yet there is no identified agency that has the money or the manpower to take this on. (ICSAC)

29. Pursue funding to strengthen Idaho's position within a future carbon market relative to that of other States. (ICSAC)

30. Pursue funding to identify which sectors within Idaho could be most affected by possible future GHG legislation. (ICSAC)

31. Continue to coordinate with and support the State's existing Idaho ICSAC and the National Association of Conservation Districts. (ISEA and the Idaho Association of Soil Conservation Districts)

32. Work with the Idaho Soil Conservation Commission and other state agencies to develop a Carbon Encumbrance Registry. (ICSAC)

\section{Buildings}

(Note that these recommendations were supported but it was mentioned several times that they were already covered in the Energy Efficiency \& Conservation Task Force Report.)

33. Establish programs to teach designing, building, and upgrading to more efficient buildings. (OER)

34. Encourage utilities to pursue building-integrated generation and energy storage. (OER)

35. Continue to support OER and ISEA in their efforts to stimulate cooperation. (OER)

36. Adopt and enforce the 2009 International Energy Conservation Code. (OER)

37. Maintain voluntary above-code standards in residential and commercial sectors. (OER)

38. Promote monitoring \& validation for buildings to help operators determine building performance. (OER)

39. Eliminate the pre-1976 limitation on tax deductions for home insulation. (OER)

40. Provide tax credit for energy efficient commercial buildings. (OER)

41. Promote building-integrated generation \& energy storage. (OER)

\section{Proposed Action Items}

In addition to these comments, the Board recommends the following State agencies as those responsible for evaluating and, if in agreement, implementing the recommended options. The Board 
requests the Council have the following units of government evaluate and decide on the assigned recommended options:

\section{- Idaho Carbon Sequestration Advisory Committee (ICSAC)}

1. Idaho should continue to participate as an observer in the Western Climate Initiative.

8. Develop a regulatory framework for geologic carbon capture and sequestration (CCS).

13. Engage industry representatives to define key technical issues limiting unconventional CCS. .

21. Proactively track potential national Cap and Trade legislation and other carbon-related 21. Proactively track potential national Cap and Trade legislation and other carbon-related regulatory legislation and policies.

22. Accelerate information and education efforts (with the Task Force).

24. Continue working with Pacific Northwest Direct Seed Association (PNDSA), U of I, and WSU in developing carbon sequestration field data on cropland, field-expedient carbon flux measuring tools, and protocols (with ICSAC).

25. Define roles \& responsibilities of involved state and federal agencies and strengthen communication between them.

26. Continue pursuing a "Designated Cropping Region" for Idaho from the Chicago Climate Exchange and pursue potential participation with the Green Exchange, New York Mercantile Exchange \& other entities.

27. Pursue funding for developing technologies for reducing GHGs from the dairy / livestock sector.

28. Pursue funding to evaluate the relative economic competitiveness of possible technologies to reduce emissions \& increase sequestration of carbon.

29. Pursue funding to strengthen Idaho's position within a future carbon market.

30. Pursue funding to identify which sectors within Idaho could be most affected by possible future GHG legislation.

32. Work with the Idaho Soil Conservation Commission and other state agencies to develop a Carbon Encumbrance Registry.

\section{- Idaho Strategic Energy Alliance Carbon Issues Task Force}

10. Lead efforts to assess federal cap-and-trade effects on Idaho.

11. Collaborate with states that export energy to Idaho to determine the impact CCS activities will have on Idaho's economy.

21. Accelerate information and education efforts, especially for the Legislature.

\section{- Department of Environmental Quality}

2. Continue to participate in The Climate Registry (TCR).

3. Encourage more Idaho companies to sign up with TCR.

4. Create a closer link between the DEQ and the OER.

5. Improve upon the State's current GHG Emissions Inventory 
6. Track what other states are doing in emissions reductions and tracking programs to help identify options for Idaho.

7. Coordinate an effort to identify Idaho opportunities to take advantage of potential offsets.

15. Resolve whether Idaho's forests are a net source of emissions or a net sink for atmospheric carbon.

16. Develop GHG inventory protocol that includes wilderness areas and is sensitive to annual change in wildfire extent.

18. Develop quantitative models of forest carbon response \& identify carbon best management practices. (with Idaho Dept. of Lands - ILD and Idaho Soil Conservation Commission - ISCC)

\section{- Office of Energy Resources}

4. Create a closer link between the DEQ and the OER.

33. Establish programs to teach designing, building, and upgrading to more efficient buildings.

34. Encourage utilities to pursue building-integrated generation and energy storage.

35. Continue to support OER and ISEA in their efforts to stimulate cooperation.

36. Adopt and enforce the 2009 International Energy Conservation Code.

37. Maintain voluntary above-code standards in residential and commercial sectors.

38. Promote monitoring \& validation for buildings to help operators determine building performance.

39. Eliminate the pre-1976 limitation on tax deductions for home insulation.

40. Provide tax credit for energy efficient commercial buildings.

41. Promote building-integrated generation \& energy storage.

\section{- Idaho Soil Conservation Commission}

18. Develop quantitative models of forest carbon response \& identify carbon best management practices (with DEQ, IDL, ISCC).

23. Continue pursuing agricultural pilot projects within the voluntary carbon trading market and prepare for integration with future national offset processes, regulations, and/or guideline (with Idaho's 51 Conservation Districts).

24. Continue working with Pacific Northwest Direct Seed Association (PNDSA), U of I, and WSU in developing carbon sequestration field data on cropland, field-expedient carbon flux measuring tools, and protocols (with ICSAC).

31. Coordinate with and support the State's existing Idaho ICSAC and the National Association of Conservation Districts.

\section{- Idaho Department of Lands}

18. Develop quantitative models of forest carbon response \& identify carbon best management practices (with DEQ and ISCC). 
20. Provide outreach efforts to develop support for active forest management. (IDL and UI Cooperative Extension)

\section{- Center for Advanced Energy Studies (CAES)}

9. Lead education \& outreach to allow for a broad-based response to the educational needs in the state with respect to policy and CCS issues.

17. Support carbon credits for a full range of forestry offset opportunities, including bioenergy (with DEQ).

\section{- Idaho Geological Survey}

12. ISEA will recommend to Idaho legislature that they charge the Idaho Geological Survey with determining Idaho's CCS potential.

\section{- University of Idaho Cooperative Extension}

20. Provide outreach efforts to develop support for active forest management (with the $U$ of I Cooperative Extension).

\section{- Idaho's Congressional Delegation}

19. Work to increase U.S. Forest Service budget for restoration-based reduction of hazardous fuels to reduce wildfire hazards, improve habitat, increase bioenergy feedstock supply, and redirects slash disposal resulting in fewer open burning emissions.

The Board requests the Council have these organizations develop a plan for evaluation and, if appropriate, implementation of these recommended options, including a timeline, for Board review. The Carbon Issues Task Force is available to assist in this endeavor.

Again, the ISEA Board is pleased to commend the work of the Carbon Issues Task Force and is pleased to submit their report to Council members for review.

Steven E. Aumeier,

Chair, ISEA Board of Directors 
Carbon Issues Task Force Options: Pros and Cons

\begin{tabular}{|c|c|c|c|}
\hline Recommendation & Page & & Explanation \\
\hline$\frac{\text { Emissions Reduction / Carbon }}{\text { Offset Credits }}$ & $9-17$ & & \\
\hline \multirow{10}{*}{$\begin{array}{l}\text { Idaho should continue to } \\
\text { participate as an observer in } \\
\text { the Western Climate Initiative }\end{array}$} & \multirow{10}{*}{14} & Pro: & $\begin{array}{l}\text { Allows state to understand what is being proposed and keep abreast of developing direction of } \\
\text { Inititative so it can be prepared and plan how best to avoid negative consequences. }\end{array}$ \\
\hline & & Pro: & Allows the state to stay up to speed on the progress of this initiative \\
\hline & & Pro: & Better positioned to identify opportunities in areas such as carbon credits \\
\hline & & Pro: & $\begin{array}{l}\text { Given the uncertainties surrounding federal climate change legislation, Idaho should continue its } \\
\text { current role as observer until such time as devoting more resources to this issue is warranted. }\end{array}$ \\
\hline & & Pro: & $\begin{array}{l}\text { Better positioned to identify potential impacts to Idaho citizens and utilities located in member } \\
\text { states }\end{array}$ \\
\hline & & Pro: & $\begin{array}{l}\text { Allows the State of Idaho to stay current with the developments of this body, and to evaluate the } \\
\text { potential benefits and consequences of participating in their pending programs. }\end{array}$ \\
\hline & & Con: & $\begin{array}{l}\text { Consumes the resources of the State in an effort that will very likely be subsumed by federal } \\
\text { climate legislation. }\end{array}$ \\
\hline & & Con: & Requires significant resources to participate in weekly calls and periodic meetings \\
\hline & & Con: & Not seen by some as an effective use of taxpayer dollars. \\
\hline & & Con: & Lends credibility to an issue seen by some as a illegitimate. \\
\hline \multirow{14}{*}{$\begin{array}{l}\text { Encourage more Idaho } \\
\text { companies to sign up with TCR } \\
\text { to be proactive }\end{array}$} & \multirow{14}{*}{4,16} & Pro: & Provides technical resources for greenhouse gas accounting \\
\hline & & Pro: & Recognition as an environmental leader \\
\hline & & Pro: & Readiness for emissions trading \\
\hline & & Pro: & Competitive advantage \\
\hline & & Pro: & $\begin{array}{l}\text { Now is the time for Idaho companies to register with TCR so that they are not caught unprepared } \\
\text { when federal climate change legislation is enacted or when Idaho decides to become an active } \\
\text { member of the WCI. }\end{array}$ \\
\hline & & Pro: & Baseline protection \\
\hline & & Pro: & Risk management \\
\hline & & Pro: & $\begin{array}{l}\text { Help companies learn what it takes to effectively report greenhouse gas emissions (GHG), } \\
\text { particularly in light of pending rules that might eventually require them to do so. }\end{array}$ \\
\hline & & Con: & Costs can be relatively high (particularly for the first year) \\
\hline & & Con: & Third party verification is required, which adds additional expense \\
\hline & & Con: & With mandatory GHG reporting required, there is less reason to join a voluntary reporting effort \\
\hline & & Con: & Uncertainty regarding exactly how this will interface with the EPA's mandatory reporting rule \\
\hline & & Con: & $\begin{array}{l}\text { Invest resources in methodologies that might not be supported by eventual (e.g. EPA) reporting } \\
\text { rules. }\end{array}$ \\
\hline & & Con: & Some believe that participation in The Climate Registry is not necessary. \\
\hline
\end{tabular}


Carbon Issues Task Force Options: Pros and Cons

\begin{tabular}{|c|c|c|c|}
\hline Recommendation & Page & & Explanation \\
\hline \multirow{7}{*}{$\begin{array}{l}\text { Create a closer link between the } \\
\text { DEQ and the OER as it relates } \\
\text { to climate change and carbon } \\
\text { regulation }\end{array}$} & \multirow{7}{*}{16,17} & Pro: & Facilitates closer and more-effective communication between these offices. \\
\hline & & Pro: & Would allow key staff members in each agency opportunities to better coordinate \\
\hline & & Pro: & Ideally, new staff could be added to each office expressly for this purpose \\
\hline & & Pro: & More "in-house" expertise for the state \\
\hline & & Con: & Requires additional resources (financial and other) \\
\hline & & Con: & $\begin{array}{l}\text { Could be a cost that might not provide an effective return depending on how state agencies are } \\
\text { impacted by pending federal legislation. }\end{array}$ \\
\hline & & Con: & May require additional staff, affecting department budgets. \\
\hline \multirow{8}{*}{$\begin{array}{l}\text { DEQ should improve upon the } \\
\text { State's current GHG Emissions } \\
\text { Inventory }\end{array}$} & \multirow{8}{*}{16,17} & Pro: & $\begin{array}{l}\text { Would help state officials better understand how to effectively report GHG emissions in the event } \\
\text { there is an eventual federal requirement to do so. }\end{array}$ \\
\hline & & Pro: & An accurate inventory is key for knowing emission sources \\
\hline & & Pro: & $\begin{array}{l}\text { Knowing emission sources allows a state to better identify opportunities and vulnerabilities when } \\
\text { it comes to regulating and trading carbon. }\end{array}$ \\
\hline & & Con: & In this time of budget cuts, this should not be pursued. \\
\hline & & Con: & Some believe this is not a productive use of taxpayer funds. \\
\hline & & Con: & Requires financial and personnel resources. \\
\hline & & Con: & $\begin{array}{l}\text { Gives the appearance that Idaho concurs with the theory of man causing global warming, a } \\
\text { theory not universally accepted. }\end{array}$ \\
\hline & & Con: & $\begin{array}{l}\text { Could be a cost (even with TCR support today) that might not provide an effective return } \\
\text { depending on how state reporting is impacted by pending federal legislation. }\end{array}$ \\
\hline \multirow{6}{*}{$\begin{array}{l}\text { Track what other states are } \\
\text { doing in emissions reductions } \\
\text { and tracking programs. }\end{array}$} & \multirow{6}{*}{16,17} & Pro: & $\begin{array}{l}\text { Would help state officials better understand how to effectively report GHG emissions in the event } \\
\text { there is an eventual federal requirement to do so. }\end{array}$ \\
\hline & & Pro: & $\begin{array}{l}\text { Would help identify non cap-and-trade and/or non-regulatory options for the state to consider (i.e. } \\
\text { Low Carbon Fuel Standards) }\end{array}$ \\
\hline & & Pro: & Much more efficient than starting from scratch \\
\hline & & Con: & Requires resources \\
\hline & & Con: & Any efforts to reduce greenhouse gas can be looked upon negatively by some \\
\hline & & Con: & $\begin{array}{l}\text { Could be a cost (even with TCR support today) that might not provide an effective return } \\
\text { depending on how state reporting is impacted by pending federal legislation. }\end{array}$ \\
\hline
\end{tabular}


Carbon Issues Task Force Options: Pros and Cons

\begin{tabular}{|c|c|c|c|}
\hline Recommendation & Page & & Explanation \\
\hline \multirow{9}{*}{$\begin{array}{l}\text { DEQ should coordinate an } \\
\text { effort to identify Idaho } \\
\text { opportunities to take advantage } \\
\text { of potential offsets }\end{array}$} & \multirow{9}{*}{17} & Pro: & $\begin{array}{l}\text { If others are willing to pay for offsets, Idaho should identify how our industries can take } \\
\text { advantage of that. }\end{array}$ \\
\hline & & Pro: & Possible financial opportunities for some sectors if carbon offsets gain value \\
\hline & & Pro: & $\begin{array}{l}\text { Could be a very useful tool to help educate offset providers (e.g. agriculture, forestry, etc.) about } \\
\text { potential market opportunities. }\end{array}$ \\
\hline & & Con: & $\begin{array}{l}\text { Could be duplicative of the efforts that will be undertaken by a wide range of industries in Idaho } \\
\text { (and elsewhere) to identify and capture offsets in meeting their own GHG objectives. }\end{array}$ \\
\hline & & Con: & Requires resources \\
\hline & & Con: & Some entities are not supportive of the use of offsets in lieu of actual emissions reductions \\
\hline & & Con: & $\begin{array}{l}\text { Some entities are hesitant to support offsets because it might infer support for carbon regulation } \\
\text { (i.e. cap-and-trade) }\end{array}$ \\
\hline & & Con: & Some think this effort is unnecessary \\
\hline & & Con: & $\begin{array}{l}\text { To some this legitimizes the notion that carbon dioxide is a pollutant rather than natural and a } \\
\text { vital plant nutrient }\end{array}$ \\
\hline \multirow{8}{*}{$\begin{array}{l}\text { DEQ should explore option for } \\
\text { developing a scaled down } \\
\text { version of a comprehensive } \\
\text { climate action plan }\end{array}$} & \multirow{8}{*}{17} & Pro: & $\begin{array}{l}\text { Would help state officials better understand how to effectively account for GHG emissions, and } \\
\text { work toward target reductions, in the event there is an eventual federal requirement for the State } \\
\text { of Idaho to do so. }\end{array}$ \\
\hline & & Pro: & $\begin{array}{l}\text { Allows the state to take a comprehensive look at the issue of climate change as it specifically } \\
\text { relates to Idaho, including emission reduction opportunities, climate adaptation } \\
\text { needs/opportunities, vulnerabilities to federal programs, etc. }\end{array}$ \\
\hline & & Pro: & $\begin{array}{l}\text { The state would be much more informed when it came time to analysis and possibly weigh in on } \\
\text { federal proposals }\end{array}$ \\
\hline & & Con: & $\begin{array}{l}\text { This would be relatively resource intensive because numerous state agencies and private } \\
\text { companies would need to be involved. }\end{array}$ \\
\hline & & Con: & This could be perceived as an attempt to "regulate" carbon emissions. \\
\hline & & Con: & The timing may be too late. \\
\hline & & Con: & $\begin{array}{l}\text { Could be an unnecessary effort if eventual federal legislation requires the actual emitters to } \\
\text { report emissions and reductions, rather than making it a requirement of the states. }\end{array}$ \\
\hline & & Con: & $\begin{array}{l}\text { By definition a comprehensive climate action plan will require reductions in emissions which will } \\
\text { require either a reduction in economic activity or implementation of costly emission controls } \\
\text { which will cause products and services to cost more and becomes a defacto tax, and therefore a } \\
\text { drain, on the economy. Neither of which will accomplish the stated goal of moderating the } \\
\text { climate. }\end{array}$ \\
\hline
\end{tabular}


Carbon Issues Task Force Options: Pros and Cons

\begin{tabular}{|c|c|c|c|}
\hline Recommendation & Page & & Explanation \\
\hline \multirow{3}{*}{$\begin{array}{l}\text { Clarify state interests and } \\
\text { opportunities associated with } \\
\text { climate and energy action, } \\
\text { particularly in the electricity, } \\
\text { transportation, and industrial } \\
\text { sectors }\end{array}$} & \multirow{3}{*}{16,17} & Pro: & Able to respond more effectively (pro or con) to federal legislative developments \\
\hline & & Pro: & Could be part or focus of option above. \\
\hline & & Con: & Would take significant resources to do it right. \\
\hline$\frac{\text { Geologic carbon sequestration }}{\underline{\& \text { Carbon Capture }}}$ & $19-23$ & & \\
\hline \multirow{4}{*}{$\begin{array}{l}\text { Develop a Regulatory } \\
\text { Framework for Geologic CCS }\end{array}$} & \multirow{4}{*}{20} & Pro: & $\begin{array}{l}\text { Critically important if Idaho intends to be in a position to permit applications for geologic } \\
\text { sequestration of atmospheric carbon. }\end{array}$ \\
\hline & & Pro: & $\begin{array}{l}\text { This will insure that the state of Idaho is prepared and should an industrial entity seek to locate } \\
\text { here and desire to store } \mathrm{CO}_{2}\end{array}$ \\
\hline & & Con: & $\begin{array}{l}\text { Would require additional resources for state regulatory entities already experiencing budget } \\
\text { shortfalls }\end{array}$ \\
\hline & & Con: & $\begin{array}{l}\text { It might be more important to understand the potential for geologic CCS in Idaho before a } \\
\text { permitting framework is developed. }\end{array}$ \\
\hline \multirow{3}{*}{$\begin{array}{l}\text { CAES will lead education \& } \\
\text { outreach }\end{array}$} & \multirow{3}{*}{22} & Pro: & $\begin{array}{l}\text { Would continue to strengthen the working relationship between the CAES member organizations, } \\
\text { the ISEA, and the OER }\end{array}$ \\
\hline & & Pro: & $\begin{array}{l}\text { Would allow for a broad-based response to the educational needs in the state with respect to } \\
\text { policy and CCS issues }\end{array}$ \\
\hline & & Con: & $\begin{array}{l}\text { CAES would need to provide the four CAES member institutions with resources and } \\
\text { management oversight to carry out this recommendation. It is unclear if this type of activity could } \\
\text { be supported in the manner necessary by CAES. }\end{array}$ \\
\hline \multirow{4}{*}{$\begin{array}{l}\text { ISEA will lead efforts to assess } \\
\text { federal cap-and-trade effects on } \\
\text { Idaho }\end{array}$} & \multirow{4}{*}{22} & Pro: & $\begin{array}{l}\text { The experts that participate on this Task Force are uniquely qualified for this activity and could } \\
\text { easily carry it out. }\end{array}$ \\
\hline & & Pro: & Would fulfill the charter of the Carbon Issues Task Force \\
\hline & & Con: & Most of the ISEA CIT members serve on a volunteer basis with their time already at a premium \\
\hline & & Con: & $\begin{array}{l}\text { Federal cap-and-trade legislation and regulation continues to be a moving target and it would be } \\
\text { difficult to come to any conclusion or recommendations until the situation changes }\end{array}$ \\
\hline
\end{tabular}


Carbon Issues Task Force Options: Pros and Cons

\begin{tabular}{|c|c|c|c|}
\hline Recommendation & Page & & Explanation \\
\hline \multirow{6}{*}{$\begin{array}{l}\text { Collaborate with states that } \\
\text { export energy to Idaho to } \\
\text { determine the impact CCS } \\
\text { activities will have on Idaho's } \\
\text { economy }\end{array}$} & \multirow{6}{*}{22} & Pro: & $\begin{array}{l}\text { Would allow Idaho to develop a closer working relationship with its neighboring states, which } \\
\text { happen to provide Idaho with the vast majority of its consumable energy resources. }\end{array}$ \\
\hline & & Pro: & $\begin{array}{l}\text { Idaho could benefit from associating with neighboring states that are much further down the CCS } \\
\text { road. }\end{array}$ \\
\hline & & Pro: & $\begin{array}{l}\text { Idaho ratepayers should be made very keenly aware of the negative impacts that carbon } \\
\text { sequestration requirements will have on their energy bills and on the economy. }\end{array}$ \\
\hline & & Pro: & A more detailed workplan describing each party/agency's responsibilities is needed \\
\hline & & Con: & $\begin{array}{l}\text { The issue of the impact of CCS performed in exporting states will either be a non-issue if energy } \\
\text { producers are not able or do not choose to employ CCS in those states. More importantly, the } \\
\text { companies using CCS - not the states - would propose how to recover those costs. If the } \\
\text { companies are regulated electric or gas utilities, then the PUC has the authority to address CCS } \\
\text { costs allocated to Idaho customers. }\end{array}$ \\
\hline & & Con: & $\begin{array}{l}\text { Would require a significant commitment of time and energy from the ISEA and specifically the } \\
\text { CIT. It is unclear where the resources for this activity would come from. }\end{array}$ \\
\hline \multirow{7}{*}{$\begin{array}{l}\text { ISEA will recommend to Idaho } \\
\text { legislature that they charge the } \\
\text { Idaho Geological Survey with } \\
\text { determining Idaho's CCS } \\
\text { potential }\end{array}$} & \multirow{7}{*}{23} & Pro: & $\begin{array}{l}\text { Idaho could "accept" other states CO2 and sequester it for a fee, thus developing a new industry } \\
\text { and revenue stream in Idaho. }\end{array}$ \\
\hline & & Pro: & $\begin{array}{l}\text { A better understanding of this potential could be valuable to future developers coming to Idaho } \\
\text { with projects that emit GHGs. Knowing that the State is prepared to help with a solution could } \\
\text { be attractive. }\end{array}$ \\
\hline & & Pro: & $\begin{array}{l}\text { Critically important in the event there are industries in Idaho that would like to implement geologic } \\
\text { CCS.stream in Idaho. }\end{array}$ \\
\hline & & Pro: & $\begin{array}{l}\text { The state would gain valuable information regarding the deep geologic terrains contained within } \\
\text { its borders. Additionally, it would provide an avenue to evaluate the geothermal potential of these } \\
\text { portions of the state }\end{array}$ \\
\hline & & Con: & The cost to conduct such a comprehensive study would be expensive and time consuming \\
\hline & & Con: & $\begin{array}{l}\text { Could be very expensive, in particular, since Idaho's geologic potential is so poorly understood at } \\
\text { present. }\end{array}$ \\
\hline & & Con: & $\begin{array}{l}\text { This effort should not be coupled with economic development because, even if geologic CCS in } \\
\text { Idaho proves possible, new industry located nearby would have to obtain sufficient CO2 emission } \\
\text { allowances, and that might prove to be impossible or, at a minimum, too expensive. If the IGS } \\
\text { obtains a legislative mandate to perform this study, it should be coupled with studying the } \\
\text { transportation of CO2 from existing sources within a reasonable distance. }\end{array}$ \\
\hline & & Con: & $\begin{array}{l}\text { Idaho could require our own industries to sequester their carbon emissions once the potential to } \\
\text { do so is established which could be very costly. }\end{array}$ \\
\hline
\end{tabular}


Carbon Issues Task Force Options: Pros and Cons

\begin{tabular}{|c|c|c|c|}
\hline Recommendation & Page & & Explanation \\
\hline \multirow{6}{*}{$\begin{array}{l}\text { Engage industry } \\
\text { representatives to define key } \\
\text { technical issues limiting } \\
\text { unconventional CCS }\end{array}$} & \multirow{6}{*}{$\begin{array}{c}4,22- \\
23\end{array}$} & Pro: & A more detailed workplan describing each party/agency's responsibilities is needed \\
\hline & & Pro: & Could help speed the development of alternative technologies. \\
\hline & & Pro: & $\begin{array}{l}\text { Idaho would certainly benefit from this development as its carbon storage options are terrestrially } \\
\text { oriented or are by definition geologically unconventional. }\end{array}$ \\
\hline & & Pro: & $\begin{array}{l}\text { Idaho should work with other experts across the nation on the development of technologies that } \\
\text { would support unconventional CCS. This effort is not occurring in a vacuum and is not unique to } \\
\text { Idaho. }\end{array}$ \\
\hline & & Con: & $\begin{array}{l}\text { Implementing this recommendation would be very expensive and given the lack of movement on } \\
\text { federal carbon legislation, return on investment is not certain. }\end{array}$ \\
\hline & & Con: & Likely a very ambitious initiative for a state with limited research capacity and especially funding. \\
\hline $\begin{array}{l}\text { Terrestrial carbon } \\
\text { sequestration on forest lands }\end{array}$ & $25-30$ & & \\
\hline \multirow{6}{*}{$\begin{array}{l}\text { DEQ will resolve whether } \\
\text { Idaho's forests are a net source } \\
\text { of emissions or a net sink for } \\
\text { atmospheric carbon }\end{array}$} & \multirow{6}{*}{5,27} & Pro: & $\begin{array}{l}\text { May provide leverage to pressure the US Forest Service to allow more intensive management on } \\
\text { national forest lands to avoid catastrophic wildfires, which are the major source of carbon in } \\
\text { forests }\end{array}$ \\
\hline & & Pro: & Answers the question: Are Idaho's forests part of the problem or part of the solution? \\
\hline & & Pro: & $\begin{array}{l}\text { The carbon database issues must be resolved to insure that Idaho's carbon footprint is not } \\
\text { mischaracterized prior to the implementatio of GHG requirements in federal law and also to } \\
\text { insure that Idaho receives credit for legitimate forest carbon offsets. }\end{array}$ \\
\hline & & Pro: & Identify opportunities to improve forest conditions and renewable energy feedstocks. \\
\hline & & Con: & $\begin{array}{l}\text { Requires concerted effort to develop consensus between the USFS, DEQ and their consulting } \\
\text { firm, and the ISEA Forestry Task Force. }\end{array}$ \\
\hline & & Con: & Does the DEQ have the expertise to do this? \\
\hline \multirow{5}{*}{$\begin{array}{l}\text { DEQ will develop GHG } \\
\text { inventory protocol that includes } \\
\text { wilderness areas and is } \\
\text { sensitive to annual change in } \\
\text { wildfire extent }\end{array}$} & \multirow{5}{*}{5,28} & Pro: & Helps answer the source-or-sink problem or solution questions above \\
\hline & & Pro: & Includes all forest lands in the state \\
\hline & & Pro: & $\begin{array}{l}\text { The verifiable measurement of both wilderness areas and wildfire impacts is critical to } \\
\text { establishing where Idaho's carbon footprint and sequestration potential stand. }\end{array}$ \\
\hline & & Pro: & Includes explicitly the largest source of GHG emissions in the state - wildfires \\
\hline & & Con: & $\begin{array}{l}\text { Requires concerted effort to develop consensus between the USFS, DEQ and their consulting } \\
\text { firm, and the ISEA Forestry Task Force. }\end{array}$ \\
\hline
\end{tabular}


Carbon Issues Task Force Options: Pros and Cons

\begin{tabular}{|c|c|c|c|}
\hline Recommendation & Page & & Explanation \\
\hline \multirow{7}{*}{$\begin{array}{l}\text { Support carbon credits for a full } \\
\text { range of forestry offset } \\
\text { opportunities, including } \\
\text { bioenergy (DEQ, CAES Energy } \\
\text { Policy Institute) }\end{array}$} & \multirow{7}{*}{5,28} & Pro: & $\begin{array}{l}\text { If others are willing to voluntarily pay for offsets, then Idaho should be positioned to provide them } \\
\text { on a voluntary basis. }\end{array}$ \\
\hline & & Pro: & $\begin{array}{l}\text { The development of supporting data for offsets will be critical. Thus, DEQ and CAES should } \\
\text { work together on white papers, databases, reports, etc., that support carbon offset proposals in } \\
\text { Idaho. }\end{array}$ \\
\hline & & Pro: & Provides incentives to practice sustainable forest management \\
\hline & & Pro: & Provides incentive for renewable energy feedstock production \\
\hline & & Pro: & Generates local employment opportunities \\
\hline & & Con: & Requires sustainable forestry certification and related expenses \\
\hline & & Con: & $\begin{array}{l}\text { Some people do not believe forestry offset projects other than afforestation are appropriate } \\
\text { means for reducing GHG emissions }\end{array}$ \\
\hline \multirow{8}{*}{$\begin{array}{l}\text { Develop quantitative models of } \\
\text { forest carbon response \& } \\
\text { identify carbon best } \\
\text { management practices (DEQ, } \\
\text { IDL, ISCC) }\end{array}$} & \multirow{8}{*}{5,29} & Pro: & Could provide greater incentives for implementing best management practices. \\
\hline & & Pro: & Defines relationship between land management actions and carbon sequestration \\
\hline & & Pro: & Reflects and rewards Idaho-specific conditions instead of regional average \\
\hline & & Pro: & $\begin{array}{l}\text { The development of supporting data for offsets will be critical. Thus, DEQ and CAES should } \\
\text { work together on white papers, databases, reports, etc., that support carbon offset proposals in } \\
\text { Idaho. }\end{array}$ \\
\hline & & Pro: & Motivates sustainable forestry practice \\
\hline & & Con: & First look to see if these types of models are already available. \\
\hline & & Con: & Requires financial resources to support research \\
\hline & & Con: & Requires sustainable forestry certification and related expenses \\
\hline \multirow{8}{*}{$\begin{array}{l}\text { Increase U.S. Forest Service } \\
\text { budget for restoration-based } \\
\text { reduction of hazardous fuels }\end{array}$} & \multirow{8}{*}{5,29} & Pro: & Any additional management of national forest lands is a positive step forward for our state. \\
\hline & & Pro: & $\begin{array}{l}\text { The resolution of this forest managment issue is long overdue. The Idaho Congressional } \\
\text { delegation should be instrumental in changing federal laws and policies to implement better } \\
\text { forest management practices. }\end{array}$ \\
\hline & & Pro: & Improves natural environment \\
\hline & & Pro: & Reduces wildfire hazards \\
\hline & & Pro: & Redirects slash disposal resulting in fewer open burning emissions \\
\hline & & Pro: & Increases bioenergy feedstock supply \\
\hline & & Con: & Requires funding for environmental analysis in addition to on-the-ground project activities. \\
\hline & & Con: & Requires financial resources to support research \\
\hline
\end{tabular}


Carbon Issues Task Force Options: Pros and Cons

\begin{tabular}{|c|c|c|c|}
\hline Recommendation & Page & & Explanation \\
\hline \multirow{8}{*}{$\begin{array}{l}\text { Provide outreach efforts to } \\
\text { develop support for active } \\
\text { forest management (IDL, UI } \\
\text { Cooperative Extension) }\end{array}$} & \multirow{8}{*}{$\begin{array}{c}5,29- \\
30\end{array}$} & Pro: & $\begin{array}{l}\text { Efforts to educate the public about the benefits of forest management and potential for renewable } \\
\text { bio-energy are positive and should be encouraged. }\end{array}$ \\
\hline & & Pro: & $\begin{array}{l}\text { Increases knowledge of benefits of managing forests to sequester carbon and provide bioenergy } \\
\text { feedstocks }\end{array}$ \\
\hline & & Pro: & These efforts might prove especially helpful to private and tribal landowners. \\
\hline & & Pro: & $\begin{array}{l}\text { Consider collaborating with forest managers to assess what activities can realistically (economics } \\
\text { and business planning) be improved. }\end{array}$ \\
\hline & & Pro: & Generates support for active forest management of national forests. \\
\hline & & Con: & Requires resources \\
\hline & & Con: & Some people will not support active forest management for any reason. \\
\hline & & Con: & Requires financial resources to support research \\
\hline$\frac{\frac{\text { Terrestrial carbon }}{\text { sequestration on agricultural }}}{\text { lands }}$ & $31-36$ & & \\
\hline \multirow{5}{*}{$\begin{array}{l}\text { Proactively track potential } \\
\text { national Cap and Trade } \\
\text { legislation and other carbon- } \\
\text { related regulatory legislation } \\
\text { and policies }\end{array}$} & \multirow{5}{*}{6,36} & Pro: & $\begin{array}{l}\text { Would help the State of Idaho better understand how industries in Idaho, which are participating } \\
\text { in carbon markets, may be impacted by developing regulation and policy. }\end{array}$ \\
\hline & & Pro: & $\begin{array}{l}\text { We need to continue to stay informed and be aware of future opportunities that present } \\
\text { themselves. }\end{array}$ \\
\hline & & Pro: & $\begin{array}{l}\text { This effort would forewarn Idaho's regulators and policy makers of major changes that would } \\
\text { impact the state }\end{array}$ \\
\hline & & Con: & $\begin{array}{l}\text { The Committee, has not been very active in the last few years and its members participate on a } \\
\text { voluntary basis, therefore any increase in activity or responsibility would require a commensurate } \\
\text { expenditure of resources }\end{array}$ \\
\hline & & Con: & $\begin{array}{l}\text { Unless there is Federal legislation that requires the active participation of individual states in } \\
\text { trading carbon credits, then this effort will likely produce no value for the citizens of Idaho. }\end{array}$ \\
\hline \multirow{4}{*}{$\begin{array}{l}\text { Develop Criteria for Measuring } \\
\text { Baseline Standards, Field } \\
\text { Evaluation Tools, and Protocols } \\
\text { for Field Validation, and } \\
\text { Develop or Enhance Carbon } \\
\text { Sequestration Models }\end{array}$} & \multirow{4}{*}{6,36} & Pro: & $\begin{array}{l}\text { Could help Idaho agricultural producers better take advantage of opportunities to participate in } \\
\text { carbon markets. }\end{array}$ \\
\hline & & Pro: & $\begin{array}{l}\text { These tools would be helpful in planning and deploying the recommended CCS activities } \\
\text { contained in this report. }\end{array}$ \\
\hline & & Con: & $\begin{array}{l}\text { It is not clear how the ICSAC would take on such activities without having the ability to allocate } \\
\text { funds to participants }\end{array}$ \\
\hline & & Con: & $\begin{array}{l}\text { Could be expensive, and duplicative of private-sector participation in the development of } \\
\text { emerging carbon markets. }\end{array}$ \\
\hline
\end{tabular}


Carbon Issues Task Force Options: Pros and Cons

\begin{tabular}{|c|c|c|c|}
\hline Recommendation & Page & & Explanation \\
\hline \multirow{4}{*}{$\begin{array}{l}\text { Accelerate information and } \\
\text { education efforts, esp. for the } \\
\text { Legislature }\end{array}$} & \multirow{4}{*}{6,36} & Pro: & $\begin{array}{l}\text { These tools would be helpful in planning and deploying the recommended CCS activities } \\
\text { contained in this report. }\end{array}$ \\
\hline & & Pro: & $\begin{array}{l}\text { Integrating the ISCC and the } 51 \mathrm{CD} \text { for this purpose of carbon mitigation/sequestration would } \\
\text { provide the baseline information to the state legislators and land managers regarding how to } \\
\text { implement agricultural-based carbon storage. }\end{array}$ \\
\hline & & Pro: & $\begin{array}{l}\text { This recommendation would provide an approximation of the credits available for carbon storage } \\
\text { in the state, and the location of that opportunity }\end{array}$ \\
\hline & & Con: & $\begin{array}{l}\text { The distribution of resources may not be equable and therefore some of the districts would } \\
\text { benefit more from this kind of effort than other would. }\end{array}$ \\
\hline \multirow{9}{*}{$\begin{array}{l}\text { The Idaho Soil Conservation } \\
\text { Commission and Idaho's } 51 \\
\text { Conservation Districts should } \\
\text { continue pursuing agricultural } \\
\text { pilot projects within the } \\
\text { voluntary carbon trading market } \\
\text { and prepare for integration with } \\
\text { future national offset } \\
\text { processes, regulations, and/or } \\
\text { guideline }\end{array}$} & \multirow{9}{*}{6,36} & Pro: & $\begin{array}{l}\text { We should position ourselves to take advantage of opportunities to benefit from those who are } \\
\text { willing to pay for offsets. }\end{array}$ \\
\hline & & Pro: & $\begin{array}{l}\text { Would be very useful for helping the agricultural community in Idaho better understand the } \\
\text { potential for participation in offset markets. }\end{array}$ \\
\hline & & Pro: & $\begin{array}{l}\text { This effort could be very useful in helping the Idaho agriculture community participate in } \\
\text { emerging offset markets. }\end{array}$ \\
\hline & & Pro: & Would provide additional revenue to Idaho's agriculture community \\
\hline & & Pro: & An additional benefit maybe that water quality and soil erosion would be reduced \\
\hline & & Con: & Potential value will be determined by the eventual rules for offsets in the agricultural sector. \\
\hline & & Con: & $\begin{array}{l}\text { Early adoption of agriculture based carbon credits may hurt the landowner, as the current price } \\
\text { for carbon credits is very low. Waiting to enroll when if and when a carbon reduction policy is in } \\
\text { place and the prices are higher would be more financially profitable for the landowner. }\end{array}$ \\
\hline & & Con: & $\begin{array}{l}\text { It's uncertain how these emerging offset markets will be treated over the long term in pending } \\
\text { federal legislation. }\end{array}$ \\
\hline & & Con: & Not everyone believes that $\mathrm{CO} 2$ needs to be controlled. \\
\hline
\end{tabular}


Carbon Issues Task Force Options: Pros and Cons

\begin{tabular}{|c|c|c|c|}
\hline Recommendation & Page & & Explanation \\
\hline \multirow{2}{*}{$\begin{array}{l}\text { The ICSAC and the Soil } \\
\text { Conservation Commission } \\
\text { should continue working with } \\
\text { PNDSA, U of I, and WSU in } \\
\text { developing carbon } \\
\text { sequestration field data on } \\
\text { cropland, field-expedient } \\
\text { carbon flux measuring tools, } \\
\text { and protocols to strengthen } \\
\text { this validation process }\end{array}$} & \multirow[b]{2}{*}{6,36} & Pro: & $\begin{array}{l}\text { Agriculture capture of carbon is still the "low hanging fruit" with low adoption cost and relatively } \\
\text { high direct and ancillary payback, the characterization of field data relative to Idaho's agriculture } \\
\text { carbon storage potential would facilitate landowner adoption options }\end{array}$ \\
\hline & & Con: & $\begin{array}{l}\text { The risk here is that the Federal Government, may never pass a national carbon emission } \\
\text { standard, if this is the case, the money spent to do the "carbon" potion of this work in large part } \\
\text { have been wasted }\end{array}$ \\
\hline \multirow{4}{*}{$\begin{array}{l}\text { The ICSAC and Carbon Issues } \\
\text { Task Force should define roles } \\
\& \text { responsibilities of involved } \\
\text { state and federal agencies \& } \\
\text { strengthen communication } \\
\text { links between them. Common } \\
\text { goals \& objectives should be } \\
\text { established through MOUs } \\
\text { and/or working agreements. } \\
\text { The potential for integrating } \\
\text { and targeting funding programs } \\
\text { and technical resources needs } \\
\text { to be evaluated. }\end{array}$} & \multirow{4}{*}{6,36} & Pro: & $\begin{array}{l}\text { A better definition of the responsibilities of these two groups would be beneficial to their ultimate } \\
\text { success. Furthermore, as the roles and responsibilities of these two groups seem to overlap, this } \\
\text { clarification would help define those areas, and make these two groups more autonomous. }\end{array}$ \\
\hline & & Pro: & $\begin{array}{l}\text { Would enhance the effectiveness of the role agencies might someday play in meeting the carbon } \\
\text { targets outlined in pending federal legislation. }\end{array}$ \\
\hline & & Con: & $\begin{array}{l}\text { Effort needs to remain commensurate with the actual regulatory role State and federal agencies } \\
\text { will play as actual emitters meet their carbon targets. }\end{array}$ \\
\hline & & Con: & $\begin{array}{l}\text { While identifying common goals is important, the establishment of MOU's and working } \\
\text { agreements has some risk. MOU's do not always facilitate the desired outcomes and often lead } \\
\text { to more confusion regarding what responsibilities each entity has relative to funding, or the lack } \\
\text { thereof. }\end{array}$ \\
\hline \multirow{2}{*}{$\begin{array}{l}\text { Pursue potential participation } \\
\text { with the Green Exchange, New } \\
\text { York Mercantile Exchange \& } \\
\text { other entities }\end{array}$} & \multirow[t]{2}{*}{6,36} & Pro: & $\begin{array}{l}\text { We should position ourselves to take advantage of opportunites to benefit from those who are } \\
\text { willing to pay for offsets. }\end{array}$ \\
\hline & & Con: & Not everyone believes that $\mathrm{CO} 2$ needs to be controlled. \\
\hline \multirow{3}{*}{$\begin{array}{l}\text { Continue working with Pacific } \\
\text { Northwest Direct Seed } \\
\text { Association, U of I, and WSU in } \\
\text { developing carbon } \\
\text { sequestration field data on } \\
\text { cropland }\end{array}$} & \multirow{3}{*}{6,36} & Pro: & $\begin{array}{l}\text { We should position ourselves to take advantage of opportunites to benefit from those who are } \\
\text { willing to pay for offsets. }\end{array}$ \\
\hline & & Pro: & $\begin{array}{l}\text { This effort would appear to be very useful in helping agricultural producers in Idaho participate } \\
\text { effectively in emerging and future offset markets. }\end{array}$ \\
\hline & & Con: & Not everyone believes that $\mathrm{CO} 2$ needs to be controlled. \\
\hline
\end{tabular}


Carbon Issues Task Force Options: Pros and Cons

\begin{tabular}{|c|c|c|c|}
\hline Recommendation & Page & & Explanation \\
\hline \multirow{2}{*}{$\begin{array}{l}\text { Pursue funding for developing } \\
\text { technologies for reducing } \\
\text { GHGs from the dairy / livestock } \\
\text { sector }\end{array}$} & \multirow{2}{*}{7,36} & Pro: & $\begin{array}{l}\text { We should position ourselves to take advantage of opportunites to benefit from those who are } \\
\text { willing to pay for offsets. }\end{array}$ \\
\hline & & Con: & Not everyone believes that $\mathrm{CO} 2$ needs to be controlled. \\
\hline \multirow{6}{*}{$\begin{array}{l}\text { Pursue funding to evaluate the } \\
\text { relative economic } \\
\text { competitiveness of possible } \\
\text { technologies to reduce } \\
\text { emissions \& increase } \\
\text { sequestration of carbon }\end{array}$} & \multirow{6}{*}{7,36} & Pro: & $\begin{array}{l}\text { We should position ourselves to take advantage of opportunites to benefit from those who are } \\
\text { willing to pay for offsets. }\end{array}$ \\
\hline & & Pro: & $\begin{array}{l}\text { Might potentially assist Industries in Idaho in meeting future carbon targets. Would have utility in } \\
\text { the event some future legislation would require the State of Idaho to account for carbon, and not } \\
\text { the actual emitters, as is currently proposed. }\end{array}$ \\
\hline & & Con: & $\begin{array}{l}\text { Would be expensive and appears to be highly duplicative (and likely far less effective) of the } \\
\text { steps Idaho industries will have to pursue in meeting their own carbon targets. }\end{array}$ \\
\hline & & Con: & Not everyone believes that CO2 needs to be controlled. \\
\hline & & Con: & $\begin{array}{l}\text { Because this organization is a volunteer group, it is unclear who would receive the funding and } \\
\text { who would do the work. There currently is not a mechanism in place for the ICSAC to accept or } \\
\text { solicit funds to do said work. }\end{array}$ \\
\hline & & Con: & $\begin{array}{l}\text { This organization is not configured to act on behalf of the state or its organization, and there is } \\
\text { not currently any pending legislation for which the organization can plan against. }\end{array}$ \\
\hline \multirow{4}{*}{$\begin{array}{l}\text { Pursue funding to strengthen } \\
\text { Idaho's position within a future } \\
\text { carbon market relative to that of } \\
\text { other States }\end{array}$} & \multirow{4}{*}{7,36} & Pro: & $\begin{array}{l}\text { We should position ourselves to take advantage of opportunites to benefit from those who are } \\
\text { willing to pay for offsets. }\end{array}$ \\
\hline & & Pro: & $\begin{array}{l}\text { Might potentially assist Industries in Idaho in meeting future carbon targets. Would have utility in } \\
\text { the event some future legislation would require the State of Idaho to account for carbon, and not } \\
\text { the actual emitters, as is currently proposed. }\end{array}$ \\
\hline & & Con: & $\begin{array}{l}\text { Would be expensive and appears to be highly duplicative (and likely far less effective) of the } \\
\text { steps Idaho industries will have to pursue in meeting their own carbon targets. }\end{array}$ \\
\hline & & Con: & Not everyone believes that $\mathrm{CO} 2$ needs to be controlled. \\
\hline \multirow{3}{*}{$\begin{array}{l}\text { Pursue funding to identify } \\
\text { which sectors within Idaho } \\
\text { could be most affected by } \\
\text { possible future GHG legislation }\end{array}$} & \multirow{3}{*}{7,36} & Pro: & $\begin{array}{l}\text { Might potentially assist Industries in Idaho in meeting future carbon targets. Would have utility in } \\
\text { the event some future legislation would require the State of Idaho to account for carbon, and not } \\
\text { the actual emitters, as is currently proposed. }\end{array}$ \\
\hline & & Con: & $\begin{array}{l}\text { Would be expensive and appears to be highly duplicative (and likely far less effective) of the } \\
\text { steps Idaho industries will have to pursue in meeting their own carbon targets. }\end{array}$ \\
\hline & & Pro: & $\begin{array}{l}\text { Idaho industries should be made very keenly aware of the negative impacts that GHG legislation } \\
\text { will have on their businesses and on the economy. }\end{array}$ \\
\hline
\end{tabular}


Carbon Issues Task Force Options: Pros and Cons

\begin{tabular}{|c|c|c|c|}
\hline Recommendation & Page & & Explanation \\
\hline \multirow{4}{*}{$\begin{array}{l}\text { ISEA and the Idaho Association } \\
\text { of Soil Conservation Districts } \\
\text { should continue to coordinate } \\
\text { with and support the State's } \\
\text { existing Idaho ICSAC and the } \\
\text { National Association of } \\
\text { Conservation Districts }\end{array}$} & \multirow{4}{*}{7,36} & Pro: & $\begin{array}{l}\text { Communication between the ISCAC and the IASC and the NACD would strengthen each groups } \\
\text { understanding of the others needs and strengths. }\end{array}$ \\
\hline & & Pro: & $\begin{array}{l}\text { Because of the charter responsibilities of the ICSAC and the IASC, it is a natural fit for the two } \\
\text { organizations to communicate on a more regular basis, especially given that two of the founding } \\
\text { members of the ICSAC are no longer engaged in either group }\end{array}$ \\
\hline & & Con: & $\begin{array}{l}\text { Most of the participants or employees of these organizations time is already heavily leveraged } \\
\text { doing their required tasks, the addition constraints on existing personnel would be unwise. }\end{array}$ \\
\hline & & Con: & $\begin{array}{l}\text { Even if there were personnel with the time to spend in this communication effort, it is unlikely } \\
\text { given budgetary constraints that financial resources could be brought to this type of activity }\end{array}$ \\
\hline \multirow{2}{*}{$\begin{array}{l}\text { ICSAC should work with the } \\
\text { Idaho Soil Conservation } \\
\text { Commission and other state } \\
\text { agencies to develop a Carbon } \\
\text { Encumbrance Registry }\end{array}$} & \multirow{2}{*}{7,36} & Pro: & $\begin{array}{l}\text { Could be useful if the State of Idaho is required by future federal legislation to account for carbon } \\
\text { encumbrance within the state. }\end{array}$ \\
\hline & & Con: & $\begin{array}{l}\text { This effort will be expensive and may add no value to the requirements that are contemplated to } \\
\text { be placed on emitters to track their own carbon performance. }\end{array}$ \\
\hline Buildings & $37-46$ & & \\
\hline $\begin{array}{l}\text { Establish programs to teach } \\
\text { designing, building, and } \\
\text { upgrading to more efficient } \\
\text { buildings }\end{array}$ & 7 & & \\
\hline $\begin{array}{l}\text { Encourage utilities to pursue } \\
\text { building-integrated generation } \\
\text { and energy storage }\end{array}$ & 8,43 & & \\
\hline $\begin{array}{l}\text { Continue to support the OER } \\
\text { and the ISEA in their efforts to } \\
\text { stimulate cooperation, } \\
\text { creativity and consensus }\end{array}$ & 8 & & \\
\hline \multirow{3}{*}{$\begin{array}{l}\text { Adopt \& enforce the } 2009 \\
\text { International Energy } \\
\text { Conservation Code }\end{array}$} & \multirow[t]{3}{*}{42} & Pro: & $\begin{array}{l}\text { Would help Idaho emitters (that sell regulated products to building owners - e.g. electric and gas } \\
\text { utilities) reduce their sales volumes and more-easily meet their own carbon targets. Should also } \\
\text { reduce the costs for these products that building owners will purchase over the life of the } \\
\text { building. }\end{array}$ \\
\hline & & Con: & Will increase the cost of building construction in Idaho. \\
\hline & & Con: & Recommendation is moot since it has already been adopted. \\
\hline
\end{tabular}


Carbon Issues Task Force Options: Pros and Cons

\begin{tabular}{|l|c|c|c|}
\hline \multicolumn{1}{|c|}{ Recommendation } & Page & & \multicolumn{1}{c|}{ Explanation } \\
\hline $\begin{array}{l}\text { Maintain voluntary above-code } \\
\text { standards in residential and } \\
\text { commercial sectors }\end{array}$ & 42 & Con: & $\begin{array}{l}\text { Anybody at any time can voluntarily build a building which is "above code". This will be done if it } \\
\text { is cost effective. Having the state of Idaho maintain such standards can easily lead to requiring } \\
\text { them which some groups cannot support. }\end{array}$ \\
\hline $\begin{array}{l}\text { Promote monitoring \& } \\
\text { validation for buildings to help } \\
\text { operators determine building } \\
\text { performance }\end{array}$ & 43 & Pro: & $\begin{array}{l}\text { Utilities, OER, or CAES could provide monitoring and validation and/or could provide educational } \\
\text { materials to building operators for self-monitoring and self-validation. The PUC would normally } \\
\text { participate in an oversight role if the utilities provided this service. }\end{array}$ \\
\hline $\begin{array}{l}\text { Eliminate the pre-1976 } \\
\text { limitation on tax deductions for } \\
\text { home insulation }\end{array}$ & 43 & Pro: & Reducing limitations will encourage investment in insulation and reduce energy consumption \\
\hline $\begin{array}{l}\text { Provide tax credit for energy } \\
\text { efficient commercial buildings }\end{array}$ & 43 & Pro: & $\begin{array}{l}\text { Tax credits will make it more affordable to implement energy saving features into new } \\
\text { construction }\end{array}$ \\
\hline $\begin{array}{l}\text { Promote building-integrated } \\
\text { generation \& energy storage }\end{array}$ & 43 & & \\
\hline
\end{tabular}


Idaho Strategic Energy Alliance

\section{Carbon lssues Task Force Report}

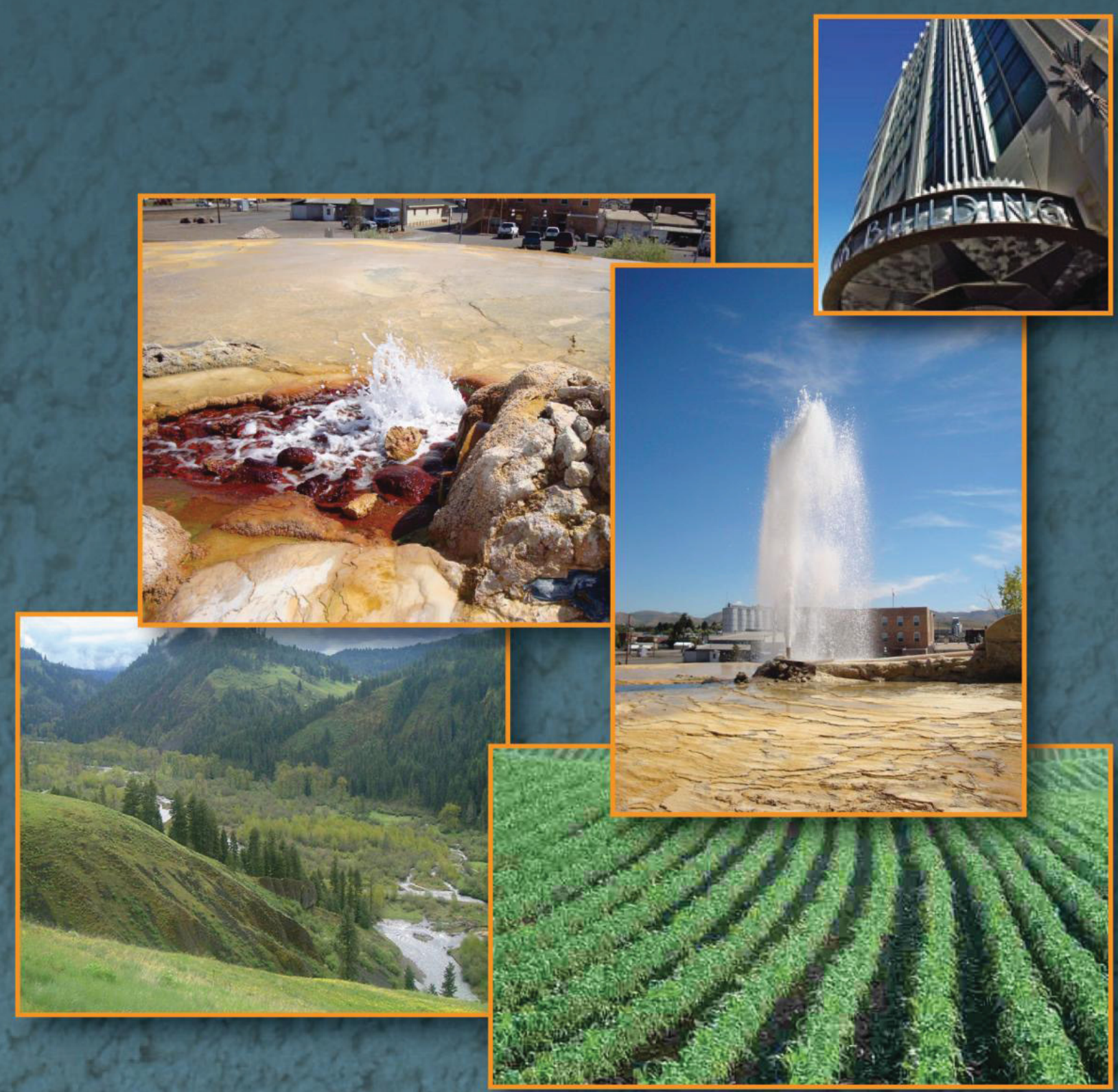

August 2010 


\section{Carbon Issues Task Force Personnel}

\begin{tabular}{|c|c|c|c|}
\hline Name & Affiliation & Telephone & E-mail \\
\hline $\begin{array}{l}\text { Chair } \\
\text { Travis McLing }\end{array}$ & $\begin{array}{l}\text { Idaho National } \\
\text { Laboratory }\end{array}$ & (208) 526-7269 & travis.mcling@inl.gov \\
\hline Tony Bennett & $\begin{array}{l}\text { Idaho Soil } \\
\text { Conservation } \\
\text { Commission }\end{array}$ & retired & \\
\hline Jess Byrne & $\begin{array}{l}\text { Idaho Department of } \\
\text { Environmental } \\
\text { Quality }\end{array}$ & (208) 373-0114 & jess.byrne@deq.idaho.gov \\
\hline Kyle Davis & PacifiCorp & (503) 813-6601 & kyle.1.davis@pacificorp.com \\
\hline Ken Eklund & $\begin{array}{l}\text { Governor's Office } \\
\text { of Energy Resources }\end{array}$ & (208) 287-4895 & ken.ecklund@oer.idaho.gov \\
\hline Mike Hoffman & $\begin{array}{l}\text { Idaho Soil } \\
\text { Conservation } \\
\text { Commission }\end{array}$ & (208) 476-4612 x105 & mike.hoffman@agri.idaho.gov \\
\hline Larry LaBolle & Avista Corp & (509) 495-4710 & larry.labolle@avistacorp.com \\
\hline Dr. Jay O'Laughlin & $\begin{array}{l}\text { University of Idaho, } \\
\text { College of Natural } \\
\text { Resources }\end{array}$ & (208) 885-5776 & jayo@uidaho.edu \\
\hline Dr. Sian Mooney & $\begin{array}{l}\text { Boise State } \\
\text { University, College } \\
\text { of Economics }\end{array}$ & (208) 426-1471 & sianmooney@boisestate.edu \\
\hline Dr. Bob Smith & $\begin{array}{l}\text { University of Idaho, } \\
\text { Center for Advanced } \\
\text { Energy Studies }\end{array}$ & (208) 282-7954 & smithbob@uidaho.edu \\
\hline Dr. Daniel Ames & $\begin{array}{l}\text { Idaho State } \\
\text { University, Dept. of } \\
\text { Geosciences }\end{array}$ & (208) 282-3235 & dpames@gmail.com \\
\hline
\end{tabular}

NOTE: Some sections and subsection of this report were written by single or dual authors because of their research, experience, or affiliation. For additional information on the focus areas listed below, the reader may wish to contact the author or authors. However, the contents of this task force report have been reviewed by all task force members, and they concur with its issuance.

1. Emissions reduction/carbon offset credits

2. Geologic carbon sequestration and carbon capture

3. Terrestrial carbon sequestration on forest lands

4. Terrestrial carbon sequestration on agricultural lands
Jess Byrne

Travis McLing

Bob Smith

Jay O'Laughlin

Tony Bennett 


\section{Table of Contents}

ACRONYMS $\mathrm{V}$

EXECUTIVE SUMMARY vii

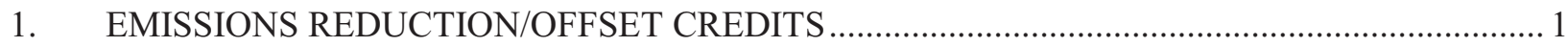

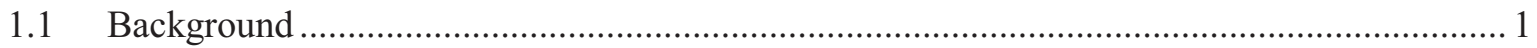

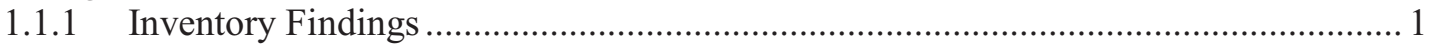

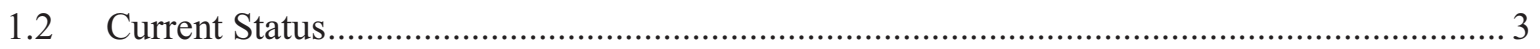

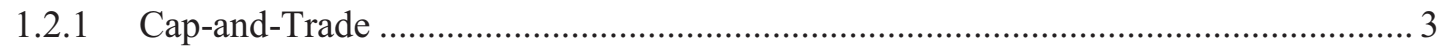

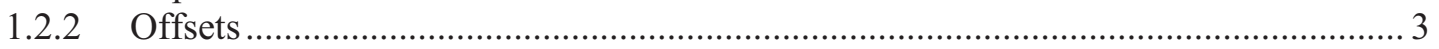

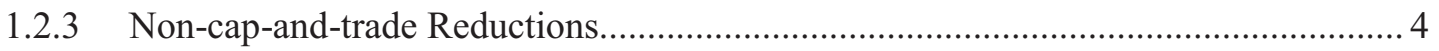

1.2.4 Regional and National Cap-and-trade Programs..................................................... 4

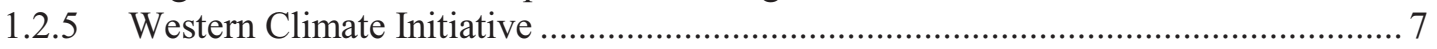

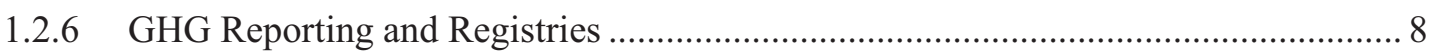

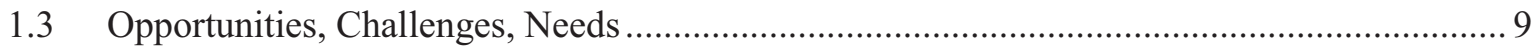

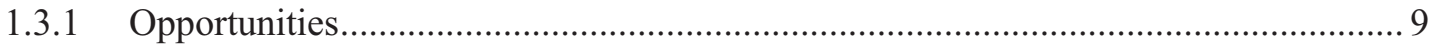

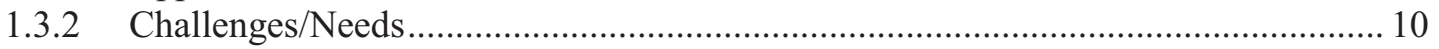

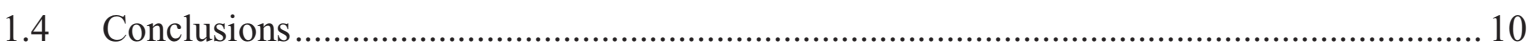

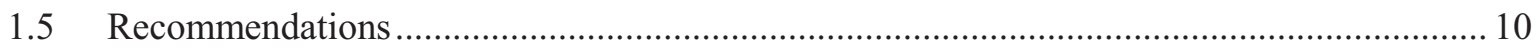

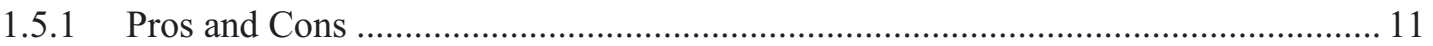

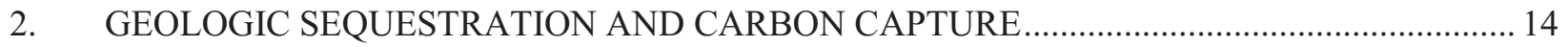

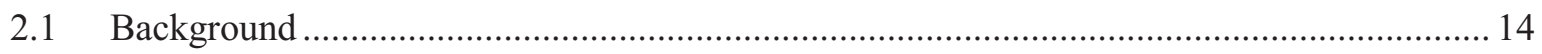

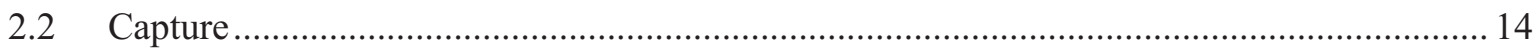

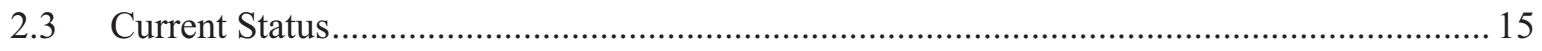

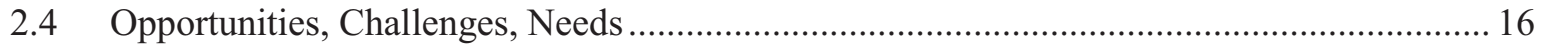

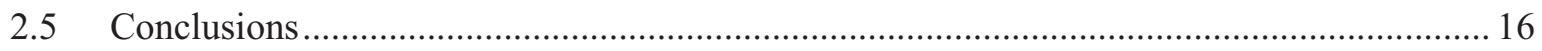

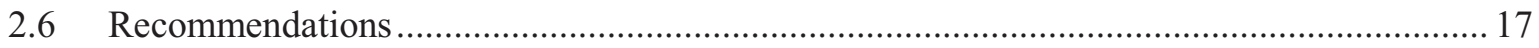

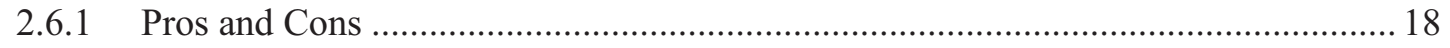

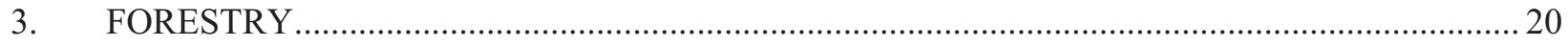

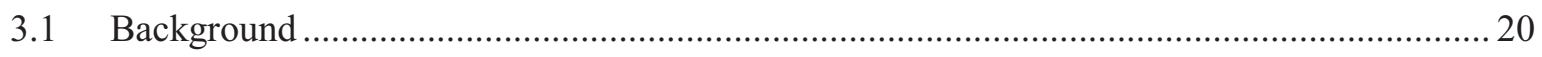

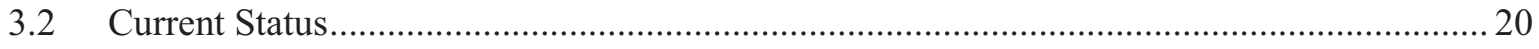

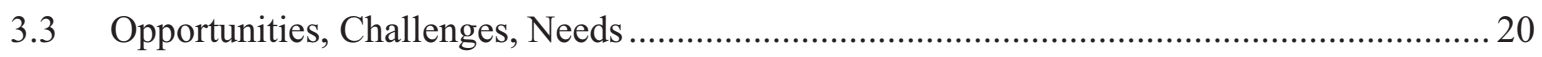

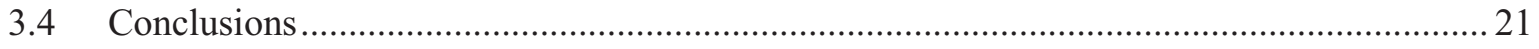

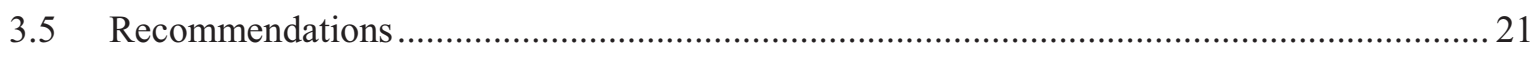

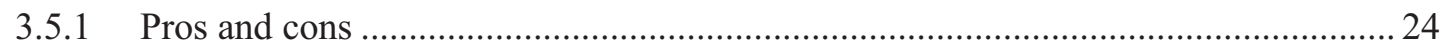

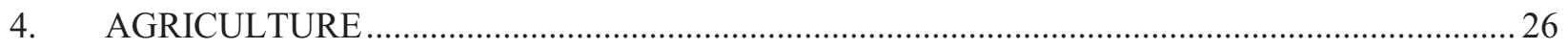

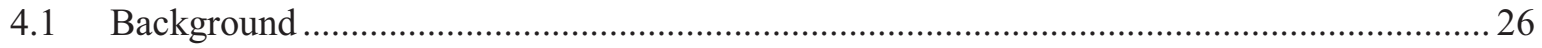

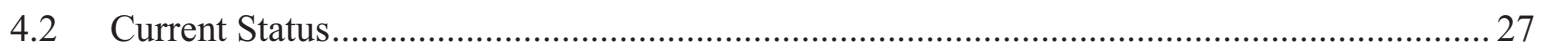

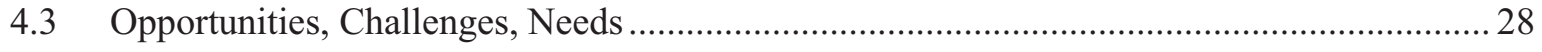

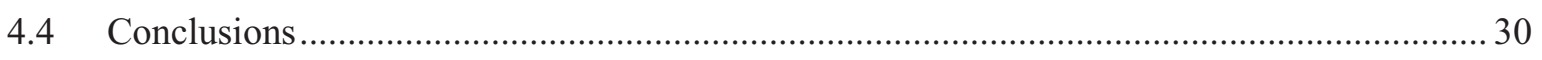

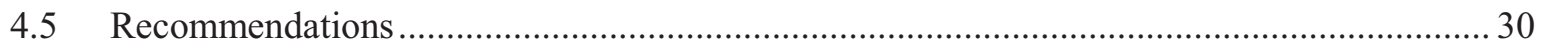




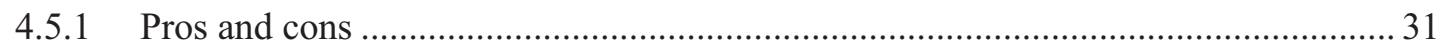

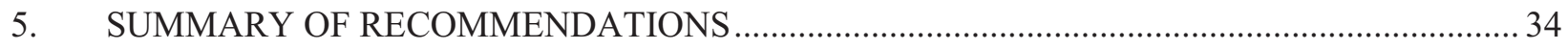

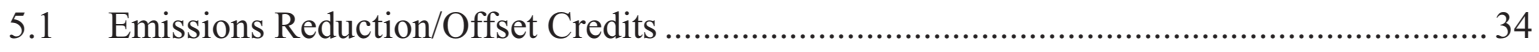

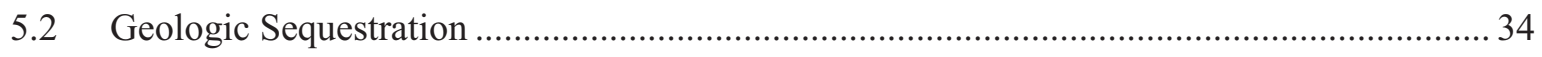

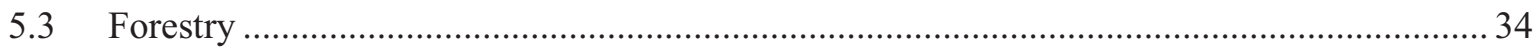

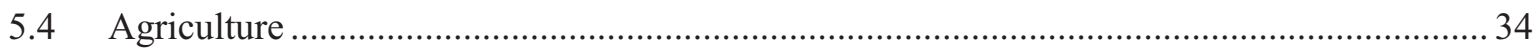

\section{FIGURES}

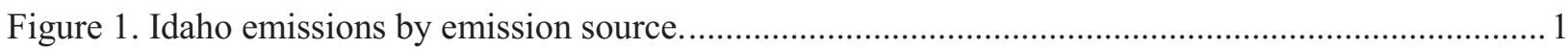

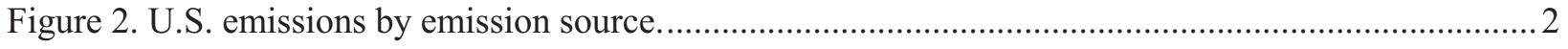

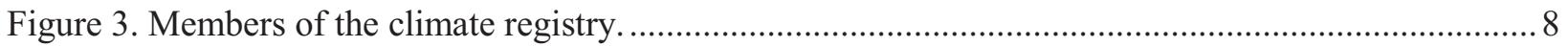

\section{TABLES}

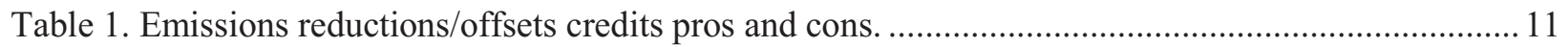

Table 2. Parasitic loss due to $\mathrm{CO}_{2}$ capture and compression at various combustion plants. ..................... 14

Table 3. Capture and compression cost for various combustion technologies. ........................................ 15

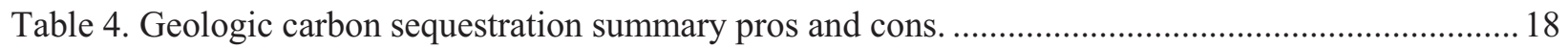

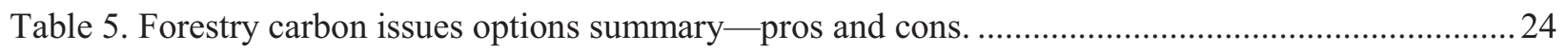

Table 6. Agriculture carbon recommendations pros and cons................................................................31

Table B-1. Idaho and U.S.A. greenhouse gas emissions by sector, million metric tons (MMt) carbon dioxide equivalent $\left(\mathrm{CO}_{2} \mathrm{e}\right)$, with percent of total by sector, 2005 ................................ 60

Table B-2. Four data sets with potential for determining forest carbon stock change from 1990 to 2005 for greenhouse gas inventory purposes (data source in each table cell).

Table B-3. Carbon flux in Idaho's forests, 2005 and 2006 (Million metric tons $\mathrm{CO}_{2}$ equivalent or $\left.\mathrm{MMt} \mathrm{CO}_{2} \mathrm{e}\right)$.

Table B-4. Idaho and U.S.A. greenhouse gas emissions by sector, million metric tons (MMt) carbon dioxide equivalent $\left(\mathrm{CO}_{2} \mathrm{e}\right)$, with percent of total by sector, 2005 . 


\section{ACRONYMS}

ACES American Clean Energy and Security

APA American Power Act

ARS Agricultural Research Service

ACELA American Clean Energy Leadership Act

BEERC Bingham Entrepreneurship and Energy Research Center

BSP Big Sky Regional Carbon Sequestration Partnership

BSU Boise State University

CAA Clean Air Act

CAES Center for Advanced Energy Study

CCS carbon capture and storage

CCS Center for Climate Strategies

CCT Carbon Calculation Tool

CCX Chicago Climate Exchange

CIT Carbon Issues Taskforce

CLEAR Carbon Limits and Energy for America's Renewal Act

CMI Carbon Management Initiative

$\mathrm{CO}_{2} \mathrm{e} \quad$ carbon dioxide equivalent

COMET computer-operated management evaluation technique

EOR enhanced oil recovery

EPA Environmental Protection Agency

FCEM Forest Carbon and Emissions Model

FIA Forest Inventory and Analysis

FIDO Forest Inventory Data Online

GHG greenhouse gas

GIS geographical information system

GWh Gigawatt Hour

HFC hydrofluorocarbon

ICSAC Idaho Carbon Sequestration Advisory Committee

IDEQ Idaho Department of Environmental Quality

IGCC integrated gasification combined cycle

INL Idaho National Laboratory

ISCC Idaho Soil Conservation Commission

ISEA Idaho Strategic Energy Alliance

ISU Idaho State University 
MMt million metric tons

$\mathrm{N}_{2} \mathrm{O} \quad$ nitrous oxide

NCAR National Center for Atmospheric Research

NCOC National Carbon Offset Coalition

NETL National Energy Technology Laboratory

NEPA National Environmental Policy Act

NGCC natural gas combined cycle

NRCS Natural Resources Conservation Service

OER Office of Energy Resources

PECPA Practical Energy and Climate Plan Act

PFC perfluorocarbon

PNDSA Pacific Northwest Direct Seed Association

PSC Public Service Commission of Wisconsin

RC\&D Resource Conservation and Development Council

RPA Rangeland Renewable Resources Planning Act

SCPC supercritical pulverized coal

SCPC-O supercritical pulverized coal oxy-combustion

SER School of Energy Resources

SPPC Sierra Pacific Power Company

TCEQ Texas Commission on Environmental Quality

TCR The Climate Registry

U of I University of Idaho

UIC Underground Injection Control

UNFCCC United Nations Framework Convention on Climate Change

U.S. United States

USDA United States Department of Agriculture

USFS United States Forest Service

WCI Western Climate Initiative

NOTE: Idaho Code 22-5103, enacted on July 1, 2002, instructed the Idaho Soil \& Water Conservation Commission (SWC) to prepare a report exploring the potential for carbon sequestration on agricultural and private, non-industrial forestlands, and provided for a 19-member Carbon Sequestration Advisory Committee (ICSAC) to be chaired by SWC. The ICSAC is partnering with several carbon sequestration entities, including the National Carbon Offset Coalition and the Big Sky Regional Partnership, in an effort develop a viable carbon market for Idaho's private ag and forest landowners. This committee is comprised of several members of the Carbon Issues Task Force, which was formed under the Idaho Strategic Energy Alliance in order to report on current issues related to carbon/greenhouse gases, potential issues, barriers, and opportunities for Idaho related to this issue, and to make recommendations on how Idaho should react and/or benefit. 


\section{EXECUTIVE SUMMARY}

When the first draft of this Taskforce report was submitted to the ISEA (Idaho Strategic Energy Alliance) Board of Directors in October 2009, it appeared that a federal Carbon Cap and Trade program was imminent in the United States. Since that time, the significant downturn on the US economy and allegations of unethical behavior by several climate change researchers has created a significant amount of uncertainty relative to any federal Cap and Trade program. This uncertainly has created a great deal of instability in the carbon markets and has made predicting the future of energy production even less certain. This uncertainty will likely continue into the foreseeable future, as the Federal Government is unlikely to move to restrict the economy through carbon legislation until economic conditions improve significantly. Eventually the fate of a federal Cap and Trade program will become known, however, until such a time, it is advised that the ISEA continue its efforts to prepare the State of Idaho for an uncertain energy future.

The Carbon Issues Task Force has five main focus areas, comprised of the following:

1. Emissions reduction/carbon offset credits

2. Geologic carbon sequestration and carbon capture

3. Terrestrial carbon sequestration on forest lands

4. Terrestrial carbon sequestration on agricultural lands

$\mid$

The purpose of this report is to address the following topics within each of the four focus areas:

a. Current situation

b. Potential

c. Barriers and challenges to development

d. Options for development.

\section{Emissions Reduction/Carbon Offset Credits}

a. Current Situation

Currently there is a lot happening in the area of green house gas (GHG) emissions reductions, both nationally and regionally, that should be noted. Most ideas for reducing GHG emissions center on the concept of developing some type of mandatory cap-and-trade regulatory program. Cap and trade is envisioned as an environmental policy tool that delivers $\mathrm{CO}_{2}$ emission reductions through a mandatory cap on emissions while providing point source emitters flexibility in how they comply. There are also many non-regulatory and non-cap-and-trade activities taking place all over the country.

b. Potential

The Western Climate Initiative (WCI) is considering allowing a large portion of their GHG emission reductions to come from offsets (almost 50\%). Carbon offsets are financial tools, and are typically achieved through financial support of project that reduces the emissions of greenhouse gasses in the short or long-term, (e.g., windfarms, flaring landfill methane, and bioenergy projects) (Hamilton et al, 2009). The WCI is a collaboration of independent jurisdictions who commit to work together to identify, evaluate, and implement policies to tackle climate change at a regional level. Other U.S. states, Canadian provinces, Mexican states, and tribes that are interested in collaborating to combat 
climate change at a regional level are encouraged to participate in the WCI as either members or observers (www.westernclimateinitiative.org).

Both Idaho's forest and agricultural industries could potentially benefit from this initiative, either through the marketing of ecosystems services, or directly through the marketing of Idaho based biofuels. There may be opportunity for carbon sequestration on forest and agricultural land and opportunities in the area of waste/manure management through the use of technologies such as anaerobic manure digesters.

c. Barriers and Challenges to Development

- Resources (funding and staff)

- Room for improvement in coordination between energy and environment growth

d. Options for Development

A "carbon constrained" economy should result in many new forms of economic development in Idaho. Some of these opportunities include cellulosic ethanol production from Idaho's farm and forestry land. Some have called it a market transformation. Idaho is a state that can be positioned well to take advantage of new "green collar" jobs that might be created and also to produce alternative forms of energy. The demand for both of these will likely increase as a cap-and-trade program goes into effect.

The Climate Registry (TCR) could also be a key component to either a regional or federal cap-andtrade program, as the results of the Registry will be a comprehensive, high quality carbon inventory, that will allow the State to understand how it will be affected by particular climate polices if adopted into regulation (WWW.theclimateregistry.org/). In order to make sure that Idaho is prepared for a potential cap-and-trade program, it's important that Idaho continues to participate in this program. It is also important that more Idaho companies sign up to register their emissions with TCR to stay ahead of the curve.

\section{Geologic Carbon Sequestration and Carbon Capture}

a. Current Situation

Geologic carbon dioxide sequestration is a process where $\mathrm{CO}_{2}$ is captured at a point source, such as a power plant, compressed, and transported via pipeline to be injected through a well into a deep subsurface formation.

The activities of the partnership in Idaho have primarily been associated with $\mathrm{CO}_{2}$ source mapping and characterization of the sequestration potential of the basalt formations of the Eastern Snake River Plain.

b. Potential

Because carbon capture and storage (CCS) is only viable for point source emitters of $\mathrm{CO}_{2}$, the advancement of geologic storage will be intimately connected with the development of new $\mathrm{CO}_{2}$-emitting facilities. The complex geology of Idaho and the limited availability of deep sedimentary basin require that unconventional CCS opportunities be explored.

c. Barriers and Challenges to Development

The potential for geologic storage in the state of Idaho is currently limited by a lack of information regarding the state's deep subsurface storage capacity. However, additional characterization of the state's potential may result in the identification of currently unknown $\mathrm{CO}_{2}$ storage locations and potential. Technology for carbon capture is largely unproven on a commercial-scale and is expensive. 
d. Options for Development

- Develop technologies required for unconventional CCS

- Engage industry representatives to define key technical issues limiting unconventional CCS

- Coordinate relevant research activities of state universities and INL through the Center for Advanced Energy Study (CAES).

\section{Terrestrial Carbon Sequestration on Forest Lands}

a. Current Situation

Idaho's forests cover $40.5 \%$ of the state. Enhancing their capability to prevent and reduce $\mathrm{CO}_{2}$ emissions is an opportunity, especially on National Forest System lands that comprise $76 \%$ of Idaho's forestlands. Because a significant amount of the Idaho's forest are on State, private, and tribal forest lands, these entities will also have roles to play in any terrestrial carbon sequestration within the State.

b. Potential

Idaho's forests in 2005 functioned as a net carbon sink for $19.5 \mathrm{MMt} \mathrm{CO}_{2}$ e that, in effect, offset $88 \%$ of GHG emissions from fossil fuel burning in the state. Because abundant tree growth forests are a

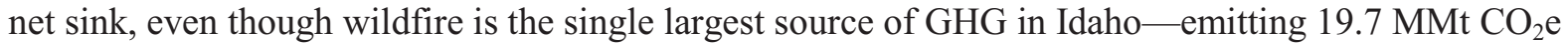
in 2005-it is equal in $\mathrm{CO}_{2}$ emissions to 3.6 million more cars on Idaho's highways. In 2006, Idaho experienced enormous wildfires with emissions equal to $160 \%$ of all fossil fuel burning emissions. Although this reduced the forest carbon sink function considerably, nevertheless due to tree growth, Idaho's forests in 2006 offset $17 \%$ of all fossil fuel combustion emissions in the state. Reducing the extent and intensity of wildfires is the leading strategy for enhancing the role of forests in mitigating GHG emissions, followed by active management to improve tree growth.

c. Barriers and Challenges to Development

The largest opportunity to enhance the carbon sequestration potential of Idaho's forests is to reduce the potential for large wildfires by reducing the amount of hazardous fuels through thinning, especially in national forests.

The largest challenge, and the most urgent, is to design socially acceptable projects for Idaho's national forests, and have durable decisions that allow managers to implement projects on the ground and budget resources to do the work. Idaho has not played an active role in such efforts.

d. Options for Development

- Resolve whether Idaho's forests are a net source of emissions or a net sink for atmospheric carbon

- Develop a GHG inventory protocol that includes wilderness areas sensitive to annual change in wildfire extent

- Support carbon credits for a full range of forestry offset opportunities, including bioenergy

- Develop quantitative models of forest carbon response and identify carbon best management practices

- Increase U.S. Forest Service (USFS) budget for restoration-based reduction of hazardous fuels

- Provide outreach efforts to develop support for active forest management. 


\section{Terrestrial Carbon Sequestration on Agricultural Lands}

a. Current Situation

At the November 15, 2007 Carbon Sequestration Advisory Committee meeting, the decision was made to use components of the Framework document ${ }^{a}$

(http://www.scc.idaho.gov/carbon\%20sequestration\%20main.htm) to help focus on five key components for implementation, and move forward on Action Items related to those key components, as follows:

- Information Outreach

- Carbon Sequestration Pilot Projects

- Technical Research

- Geologic Sequestration

- Carbon Encumbrance Registry for the state of Idaho.

b. Potential

The opportunities for Idaho agriculture to sequester carbon and reduce other greenhouse gases are tremendous. "Idaho has the potential to sequester and/or offset nearly 15 million metric tons of carbon dioxide equivalents $\left(\mathrm{CO}_{2} \mathrm{e}\right)$ per year. Afforestation (planting trees or seeds in order to transform open land into forests), biofuels production, biogas recovery, no-till, nutrient management, methane reductions, and agricultural energy reductions could provide most of the state's sequestration and emission offsets."

c. Barriers and Challenges to Development

The main concern is that Idaho is largely dependent upon national political and regulatory decisions that have yet to be made.

- Will the U.S. have a national "Cap-and-Trade" program?

- What will the ramifications be on the current voluntary market?

- To what degree will agriculture be considered as part of the solution?

The second challenge involves the economic potential of adopting practices and strategies that sequester carbon within the agricultural sector.

d. Options for Development

1. Proactively track potential national Cap-and-Trade legislation or other regulatory legislation and policies that may impact carbon trading opportunities or future markets. Responsible Party: Idaho Carbon Sequestration Advisory Committee

2. The Idaho Carbon Sequestration Advisory Committee will proactively track potential national Cap-and-Trade legislation or other regulatory legislation and policies that may impact carbon trading opportunities or future markets (See Appendix A).

3. Accelerate information and education efforts through the Idaho Carbon Sequestration Advisory Committee and Idaho's 51 local Soil Conservation Districts. Special emphasis should be placed on updating and informing the Legislature. Responsible Party: Idaho Carbon Sequestration Advisory Committee

4. Continue pursuing agricultural pilot projects within the voluntary carbon trading market. Responsible Party: Idaho Soil Conservation Commission and Idaho's 51 Conservation Districts

a. Carbon Sequestration on Idaho Agriculture and Forest Lands, p.p. 2, 3, February 2003.

b. Carbon Sequestration on Idaho Agriculture and Forest Lands, p.p. 2, 3, February 2003. 
5. Continue pursuing a "Designated Cropping Region" for Idaho from the Chicago Climate Exchange. Also, pursue potential participation with the Green Exchange, New York Mercantile Exchange, and possible trading opportunities directly with private entities. Responsible Party: Idaho Carbon Sequestration Advisory Committee

6. Continue working with Pacific Northwest Direct Seed Association (PNDSA), University of Idaho, and Washington State University in developing carbon sequestration field data on cropland. Responsible Party: the Idaho Soil Conservation Commission and the Idaho Carbon Sequestration Advisory Committee

7. Pursue funding for:

- Developing and implementing technologies for reducing GHG from the dairy and livestock sector

- Evaluating the relative economic competitiveness of possible technologies to reduce emissions and increase sequestration of carbon

- Strengthening Idaho's position within a future carbon market relative to that of other states

- Identifying which sectors within Idaho could be most affected by possible future GHG legislation.

Responsible Party: Idaho Carbon Sequestration Advisory Committee

8. The Idaho Carbon Sequestration Advisory Committee should better define roles and responsibilities of involved state and federal agencies, and strengthen communication links between agencies. Common goals and objectives are established through MOUs and/or working agreements. The potential for integrating and targeting funding programs and technical resources will be evaluated.

9. The Idaho Strategic Energy Alliance and the Idaho Association of Soil Conservation Districts should continue to coordinate with and support the state's existing Idaho Carbon Sequestration Advisory Committee (ICSAC).

10. The Idaho Carbon Sequestration Advisory Committee should work with ISCC, The Center for Advanced Energy Studies and other state agencies to develop a Carbon Encumbrance Registry. 


\section{Idaho Strategic Energy Alliance Carbon Issues Task Force Report}

\section{EMISSIONS REDUCTION/OFFSET CREDITS}

\subsection{Background}

When looking at the broad category of "carbon issues," a critical component of analyzing for the state of Idaho involves knowing what our sources of carbon emissions are. This is important particularly in the context of reducing those emissions (either voluntarily or mandatorily). Efforts to reduce emissions don't necessarily have to come from within state boundaries, but can also be placed upon carbon emission sources by other entities, such as the federal government. From this perspective, knowing current carbon emissions levels can serve a variety of purposes, including identifying a baseline for future reductions as well as identifying vulnerabilities if mandatory reduction requirements are set. For example, as is noted in the 2007 Idaho Energy Plan, "Idaho's reliance on coal-fired power leaves the state vulnerable to the economic effects of federal regulation of carbon dioxide and mercury emissions." These and other vulnerabilities can be identified by completing a state-wide greenhouse gas emissions inventory. http://WwW.energy.idaho.gov/informationresources/d/energy_plan_2007.pdf

In early 2008, the Center for Climate Strategies (CCS) finalized a greenhouse gas (GHG) Inventory Report for the state of Idaho. The purpose of this inventory was to give the state an idea of how it compares to the rest of the nation and identify the sources of GHG emissions. It also made projections on future emissions based on current trends. The report was developed using existing data that was available at the time of its creation. The report will be improved upon as better and more accurate data becomes available. A copy of the report can be found at http://www.deq.idaho.gov/air/prog issues/ghg/pdfs/ghg inventory idaho sp08.pdf, or can be obtained from the Idaho Department of Environmental Quality at 1410 N. Hilton in Boise, Idaho.

\subsubsection{Inventory Findings}

Compared nationally, Idaho is a low GHG-emitting state. Activities in Idaho accounted for approximately 37 million metric tons (MMt) of gross carbon dioxide equivalent $\left(\mathrm{CO}_{2} \mathrm{e}\right)$ emissions in 2005. This is an amount equal to about $0.5 \%$ of total U.S. gross GHG emissions (around $47^{\text {th }}$ nationally). Despite being a relatively low emitter, Idaho's gross GHG emissions increased 31\% from 1990 to 2005 , while national emissions rose by only $16 \%$ over a similar period. Idaho's per capita emissions rate is also slightly higher than the

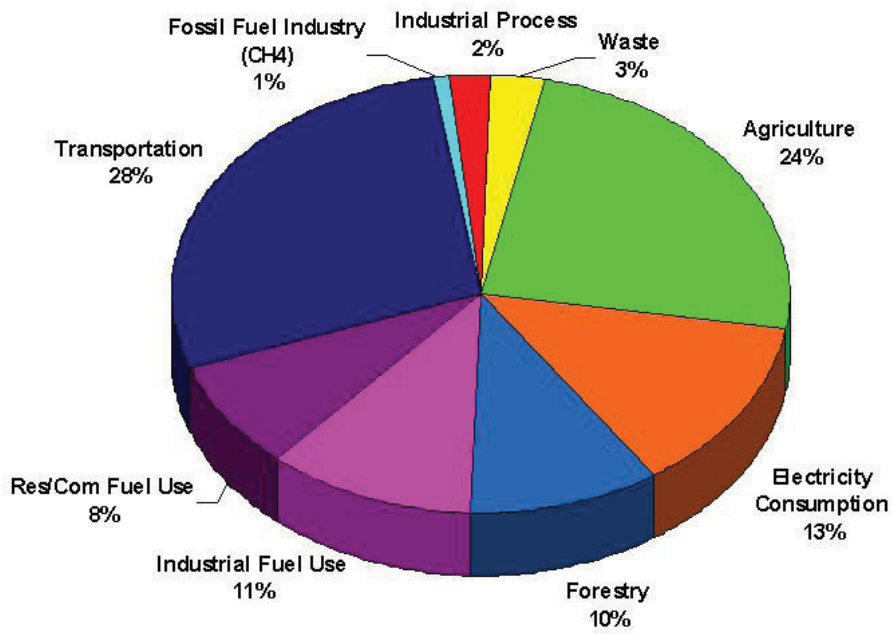

Figure 1. Idaho emissions by emission source. national average of $25 \mathrm{MtCO}_{2} \mathrm{e} / \mathrm{yr}$. During the time period between 2000 and 2005, Idaho's average per capita emission rate was $26 \mathrm{MtCO}_{2} \mathrm{e} / \mathrm{yr}$. 
According to the emissions inventory, transportation is responsible for the largest portion of the state's emissions, followed by agriculture, electricity consumption, industrial fuel use, and forestry. More information about each of these sectors is discussed below. Forestry is covered comprehensively in the Forestry section of this report. Idaho's emissions profile varies significantly from the national figures in a couple of areas (see Figures 1 and 2).

\subsubsection{Transportation}

Transportation is the largest source of GHG emissions for Idaho at 28\%. This is a result of gasoline and diesel combustion. This percentage is comparable to the percent nationally that is attributed to transportation $(26 \%)$.

\subsubsection{Agriculture}

Agriculture is Idaho's secondlargest source of GHG emissions at $24 \%$. The primary activities that account for these emissions are enteric fermentation and manure management associated with large livestock feeding operations. Activities associated with crop residue burning and agricultural soil tillage practices also contribute significantly to this source of GHG emissions.

\subsubsection{Electricity}

Electricity consumption accounted for $13 \%$ of the state's GHG emissions. However, the bulk of that was from imported

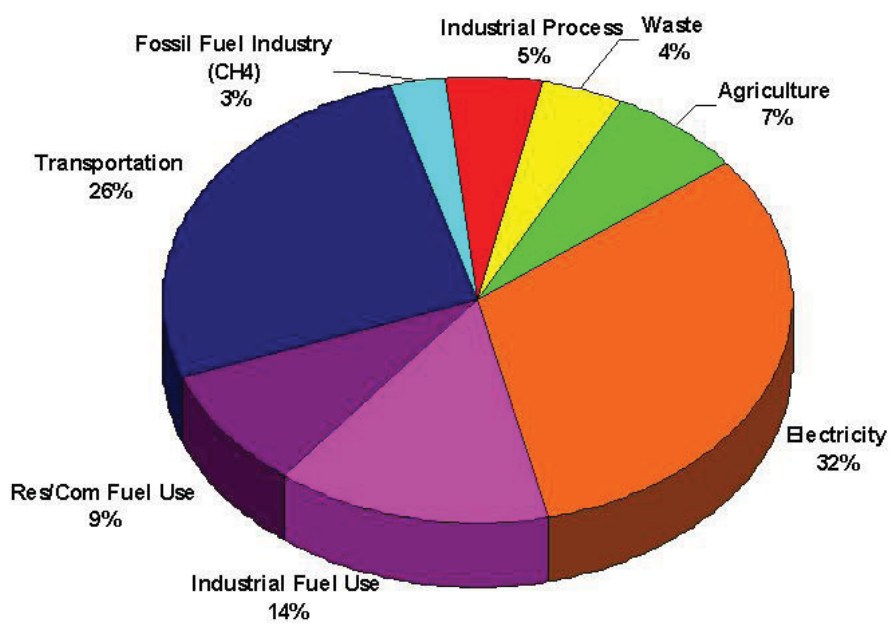

Figure 2. U.S. emissions by emission source. electricity. Electricity production within the state accounted for approximately $1 \%$ of the state's emissions, and this comes from the occasional burning of natural gas. The remainder comes from electricity that is generated outside of Idaho but imported for consumption. Idaho imports electricity that is generated using coal and natural gas combustion. Idaho has no utility coal-fired power generation in-state. Nationally, electricity production is the largest source of GHG emissions (32\%). Idaho (13\%) is much lower because of the state's hydroelectricity generating capacity and due to the fact that our coalbased generating resources are located outside our state's borders.

In the electricity sector, industrial use is $40 \%$, residential $35 \%$, and commercial $26 \%$. Residential and commercial use is often lumped together as buildings, since the bulk of the electricity used is for space conditioning, lighting, and other uses associated with buildings. Electrical consumption from buildings continues to be Idaho's fastest growing area, and will account for increasing energy use and emissions. As discussed above, residential and commercial buildings use $61 \%$ of Idaho's electricity, accounting for 3.2 MMt of emissions. In addition, residential buildings create 7\% of Idaho's fossil fuel emissions and commercial buildings create 4\%, for a total fossil fuel contribution of 1.6 MMt (Sightline Institute). The combined total of electric and fossil fuel emissions for Idaho's buildings sector is $4.8 \mathrm{MMt}$ or $13 \%$ of Idaho's emissions total.

Thus Idaho's buildings sector uses $61 \%$ of Idaho's electricity (13,215 GWh or 3.2 MMt). 


\subsubsection{Industrial Processes and Industrial Fuel Use}

Industrial processes and industrial fuel use in Idaho accounted for about 13\%, compared to $19 \%$ nationally. Most of this comes from the burning of coal, natural gas, oil, and wood for heating purposes. The remainder is from cement, lime, and semi-conductor manufacturing and industrial processes that emit fluorinated gases.

\subsubsection{Forestry}

According to the results of the GHG inventory, forestry accounts for 10\% of Idaho's GHG emissions. Potential errors in the U.S. Department of Agriculture data used to calculate these emissions have been identified. This will be discussed further in the Forestry section of this document.

\subsection{Current Status}

Recently there has been a lot of activity in the area of GHG emissions reduction policy, both nationally and regionally, that should be noted. Most ideas for reducing GHG emissions center on the concept of developing some type of mandatory cap-and-trade regulatory program. There are also many non-regulatory and non-cap-and-trade activities taking place all over the country. Below are some key definitions and explanations of some of the major concepts associated with greenhouse gas emission reductions, followed by information regarding regional and national efforts that have been initiated or proposed.

\subsubsection{Cap-and-Trade}

A cap-and-trade system enforces a limit on greenhouse gas emissions, sets goals for reducing emissions over time, and uses the private sector market to achieve these goals. The scope and details of a cap-and-trade program can vary widely, but the basic principle is the same.

In a cap-and-trade system, a central authority (usually a government or international body) sets a limit, or cap, on the amount of a pollutant that can be emitted. Companies or other groups are issued emission permits and are required to hold an equivalent number of allowances (or credits) which represent the right to emit a specific amount. The total amount of allowances and credits cannot exceed the cap, limiting total emissions to that level. Companies that need to increase their emissions must buy credits from those who reduce theirs. The transfer of allowances is referred to as a trade. In effect, the buyer is paying a charge for polluting, while the seller is being rewarded for having reduced emissions by more than was needed. Thus, in theory, those that can easily reduce emissions most cheaply will do so, achieving the emissions reduction at the lowest possible cost to society. (http://en.wikipedia.org/wiki/cap-and-trade)

\subsubsection{Offsets}

An important component of a cap-and-trade program or system is offsets. Offsets are reductions in emissions that are legally or geographically outside the cap but that are honored like carbon allowances under the cap. For example, an electric utility in the Northwest might buy a 1-ton carbon offset-for one ton of $\mathrm{CO}_{2}$ removed permanently from the atmosphere - from an Idaho forest land owner who put a legally binding (and permanent) conservation easement on his/her land and thereby soaked up and sequestered, or stored, one ton of $\mathrm{CO}_{2}$. Alternatively, an oil company in Wyoming might buy 100 offsets from a coal-fired power plant in China that shut down one of its generators and replaced the power through conservation programs. To use the offsets under the cap-and-trade program, the electric utility or oil company would present public officials with documentation of the offsets as a substitute for an equal number of carbon allowances. There are many concerns and even criticisms of a cap-and-trade program that allows for too much of the reductions to come from offsets and not enough of from emitters within the program. This is an issue that is still being discussed for programs that are currently being proposed. (www.worldchanging.com/archives/008337.html) 


\subsubsection{Non-cap-and-trade Reductions}

There are many regulatory and non-regulatory actions that can be taken outside of a cap-and-trade program that will result in GHG emission reductions. Carbon tax proposals are potential substitutes for the cap-and-trade approach. Others, for example, in the area of transportation and land use, include low carbon fuels and higher standards for vehicle fuel mileage or emissions. Additionally, improvements to transportation systems, availability of consumer information on vehicle miles per gallon, and use of biomass can all result in emission reductions. Similarly, more robust building energy codes and appliance standards can be used in residential, commercial, and industrial buildings. Likewise, consumer education and energy efficiency programs are also options. Many of these areas will probably be discussed by the conservation and efficiency task forces and therefore are only mentioned in passing in this report.

\subsubsection{Regional and National Cap-and-trade Programs}

Multiple regional GHG cap-and-trade programs are in the works (Western Climate Initiative, Midwest Cap-and-Trade Accord, and Regional Greenhouse Gas Initiative). As of last year (2009), these three initiatives combined represent almost $50 \%$ of the nation's population and $80 \%$ of Canada's. (http://daily.sightline.org/daily_score/archive/2008/08/20/inside-wci-pre-emption)

A national cap-and-trade program has been proposed a number of times in the recent past. President Barack Obama has voiced his support for a national cap-and-trade program. He appointed Carol Browner as Assistant for Energy and Climate Change, a new position in his administration, and has begun to outline his vision for a comprehensive plan. In President Obama's first proposed budget, he stated that:

The Administration is developing a comprehensive energy and climate change
plan to invest in clean energy, end our addiction to oil, address the global
climate crisis, and create new American jobs that cannot be outsourced. After
enactment of the Budget, the Administration will work expeditiously with key
stakeholders and Congress to develop an economy-wide emissions reduction
program to reduce greenhouse gas emissions approximately $14 \%$ below 2005
levels by 2020, and approximately $83 \%$ below 2005 levels by 2050. This program
will be implemented through a cap-and-trade system...
(http://www.whitehouse.gov/omb/assets/fy2010_new_era/A_New_Era_of_Respo
nsibility2.pdf)

Though the President has been unsuccessful thus far in moving his national cap-and-trade program agenda forward, all signs seem to indicate that he will continue to try.

Additionally, several bills have already been introduced in Congress over the last couple of years, and one actually passed the House of Representatives. In June 2009, the U.S. House of Representatives passed a comprehensive climate and energy bill, the American Clean Energy and Security Act (H.R. 2454). The U.S. Senate has been considering a number of related proposals, ranging from "energy only" bills, such as the American Clean Energy Leadership Act (S.1462) to proposals that place an economy-wide cap on greenhouse gas emissions, such as the American Power Act.

Below is a list of the major legislative proposals currently in Congress. More information can be found at the following link: http://WwW.pewclimate.org/federal/policy-solutions/climate-policymemo/major-climate-and-energy-proposals-111th-congress, including Congressional Budget Office cost estimates for each of the proposals. 
- American Clean Energy Leadership Act (ACELA)

Sponsored by Senator Jeff Bingaman (D-NM), ACELA (S. 1462), it was passed out of the Senate Energy and Natural Resources Committee on June 17, 2009, with a bipartisan vote of 15 to 8, and was amended by the Committee with unanimous consent on May 6, 2010. This energy bill includes provisions on increased energy production, energy efficiency, renewable energy standards, technology research and development, energy market stabilization, and transmission network improvements.

- $\quad$ Carbon Limits and Energy for America's Renewal (CLEAR) Act

Introduced by Senators Maria Cantwell (D-WA) and Susan Collins (R-ME) on December 1, 2009, the CLEAR Act (S.2877) is intended to provide a transparent and equitable approach to energy independence and climate change mitigation. The bill couples a cap on $\mathrm{CO}_{2}$ emissions from fossil fuel producers and importers (i.e., a cap on upstream entities), auctions off all $\mathrm{CO}_{2}$ allowances, and provides a dividend back to individuals and funding for clean energy technology.

- $\quad$ American Power Act (APA)

Senators John Kerry (D-MA) and Joe Lieberman (I-CT) released the discussion draft of their comprehensive climate and energy bill on May 12, 2010. The bill contains a comprehensive, sector-based approach to enhancing energy security, spurring the development and deployment of clean energy technologies, and reducing greenhouse gas (GHG) emissions. It includes a cap on GHG emissions, a mix of approaches to allowance distribution that varies by sector and over time (with initial allocations to consumers through local distribution companies), provisions on domestic clean energy development, consumer protection, job protection and growth, international climate change activities, and community protection from global warming impacts.

- $\quad$ Practical Energy and Climate Plan Act (PECPA)

Senators Richard Lugar (R-IN), Lindsay Graham (R-SC), and Lisa Murkowski (R-AK) introduced PECPA (S. 3464) on June 9, 2010 in order to make meaningful progress on energy-driven national security, economic, and environmental concerns. Unlike other major energy-climate bills, the PECPA seeks to reduce GHG emissions by reducing oil imports, improving and creating new efficiency standards, and establishing a clean energy standard. It does not include a cap on greenhouse gases or a price on carbon.

- American Clean Energy and Security (ACES) Act

Representatives Henry Waxman and Edward Markey introduced the ACES Act (H.R. 2454) in March 2009, and it was passed the U.S. House of Representatives by a vote of 219 to 212 on June 26, 2009. This comprehensive national climate and energy legislation includes an economy-wide, GHG cap-and-trade system and complementary measures, such as energy efficiency standards, and carbon capture and storage and electric vehicle incentives. This legislation places limits on emissions of GHG. It aims to cut U.S. global warming pollution by $17 \%$ compared to 2005 levels in 2020 , by $42 \%$ in 2030 , and by $83 \%$ in 2050 . The initial discussion draft, released at the end of March, was 648 pages. The first legislative version of that draft (H.R. 2454) was passed out of the House Committee on Energy and Commerce and vetted by eight different House Committees. The engrossed version that passed the House of Representatives is 1428 pages. It would impact nearly every facet of the economy. In addition to putting a cap on carbon emissions, this legislation has titles that promote clean energy, energy efficiency, and green jobs. The legislation also currently has language that would pre-empt states and any other political subdivisions from implementing and enforcing a cap-and-trade program between the years of 2012 through 2017).

Despite the large number of proposals, and what appeared to be early momentum for proponents of a comprehensive national cap-and-trade program, the pendulum now seems to be swinging the other direction. Opponents of cap-and-trade (or at least the forms that had been proposed thus far) have raised enough questions with the proposals and doubts over whether cap-and-trade is the best way to achieve 
emission reductions overall. As such, you are now starting to see "comprehensive" energy proposals introduced in Congress without a carbon emission reduction strategy. As an important side note, Governor Otter, Idaho's Congressional delegation, and the state legislature all expressed their opposition to the Waxman Markey legislation in one form or another. Most concerns related to the financial/economic impacts associated with the proposal while other concerns centered around the manner in which such broad sweeping legislation was somewhat hastily moved forward.

\subsubsection{Discussion}

On top of the diverse preferences for climate action reflected in the above measures, the economic, political, and international landscape has changed markedly since H.R.2454 passed the House last summer. Copenhagen took a somewhat unexpected turn and recent unprofessional actions by several climate scientists have raised doubts about the science. The Massachusetts Senatorial election has altered not only the balance of power in the Senate, but shown that all participants in political gridlock are at risk. Further, the Senate's legislative calendar is overflowing with healthcare, jobs, financial reform, and other major legislation. Against this backdrop, it is difficult to envision passage of any climate and energy legislation in the 111th Congress. If climate and energy legislation is not adopted prior to the 2010 midterm elections, Congressional action would appear unlikely until at least late 2011 , and quite possibly not until 2013 - after the next presidential election. To summarize the current status of federal climate policy, it's probably fair to say that uncertainty regarding what form U.S. federal climate policy will take if it is eventually passed and when it will be adopted has rarely been greater.

Recent efforts have failed to put forward a proposal with broad enough support to move forward. As a state that opposed the Waxman/Markey proposal, that can be viewed as a positive thing. However, it's also important to note that Congress' inability to come up with some sort of acceptable path forward also leaves the regulated community in somewhat of a state of limbo, making it more difficult for them to include comprehensive carbon policy in their long-term future planning and does not mean that they are "safe" from carbon regulation. Below are some examples that highlight the regulated community's susceptibility to other forms of carbon regulation.

\section{EPA GHG "Endangerment" and "Cause or Contribute" Findings}

Before EPA can regulate emissions as pollutants under the Clean Air Act, it must determine, on the basis of the best available scientific information, that they endanger public health and welfare. Before EPA can regulate emissions of such pollutants from certain emission sources, it must also determine that emissions from those sources "cause or contribute" to the threat to public health and welfare. On December 7, 2009, EPA Administrator Lisa Jackson signed a finding that current and projected concentrations of six key GHG in the atmosphere threaten the public health and welfare of current and future generations. The six gases are the same ones targeted by the UNFCCC and in Congressional proposals: $\mathrm{CO}_{2}$, methane $\left(\mathrm{CH}_{4}\right)$, nitrous oxide $\left(\mathrm{N}_{2} \mathrm{O}\right)$, hydrofluorocarbons ${ }^{\mathrm{c}}(\mathrm{HFCs})$, perfluorocarbons ${ }^{\mathrm{d}}$ (PFCs), and sulfur hexafluoride ${ }^{\mathrm{e}}\left(\mathrm{SF}_{6}\right)$. At the same time, she also signed a "cause or contribute" finding that the combined emissions of these GHGs from new motor vehicles and new motor vehicle engines contribute to the GHG pollution which threatens public health and welfare. http://www.epa.gov/climatechange/endangerment/downloads/Federal Register-EPA-HQ-OAR-20090171-Dec.15-09.pdf

Strictly speaking, these findings do not yet represent GHG emission reduction requirements and so far only apply to new vehicles and engines. But the extrapolation to other GHG emission sources is apparent under the Clean Air Act, and regulations to require reductions will likely follow. Although their initial regulatory impact will be to enable EPA to finalize proposed emission standards for new vehicles, there is

\footnotetext{
${ }^{\mathrm{c}}$ HFCs are primarily used as a substitute for ozone-depleting chemicals but can have an atmospheric lifetime of up to 15 years

${ }^{\mathrm{d}}$ PFCs are extremely potent greenhouse gases, and can have a lifetime up to 50,000 years due to the fact that they are largely immune to the chemical processes in the lower atmosphere that break down most atmospheric pollutants

${ }^{e} \mathrm{SF}_{6}$ is the most potent greenhouse gas due to its extremely efficient and effective warming potential
} 
no suspense about the advent of GHG controls for other source categories as well. On this basis, a number of challenges against EPA's endangerment finding have been filed by industry groups, conservative think tanks, lawmakers, and states (Alabama and Virginia). Sixteen other states and New York City have filed in support of EPA's finding. (http://www.nytimes.com/gwire/2010/02/17/17greenwire-16-endangermentlawsuits-filed-againstepa-bef-74640.html) On July 29, 2010 EPA rejected petitions challenging the greenhouse gas endangerment finding, essentially holding up the original December 9, 2009 decision.

\section{EPA Mandatory Reporting of GHG Emissions}

As instructed by Congress in December 2007 as part of an omnibus federal appropriations bill, EPA issued rules for mandatory reporting of GHG emissions on October 20, 2009. The rule requires GHG reporting, starting in 2010, from large sources and suppliers. Suppliers of fossil fuels or industrial greenhouse gases, manufacturers of vehicles and engines, and facilities that emit 25,000 metric tons or more per year of GHG emissions are required to submit annual reports to EPA. EPA is still finalizing the rule for several other source categories. The data collected will provide a better understanding of where GHGs are coming from and will guide development of future policies and programs to reduce GHG emissions. (http://www.epa.gov/climatechange/emissions/ghgrulemaking.html)

\section{EPA Proposed GHG Permitting Requirements on Large Industrial Facilities}

On September 30, 2009, EPA proposed permitting thresholds for GHG emissions from large stationary sources. This rule would define when Clean Air Act (CAA) permits under the New Source Review and Title $\mathrm{V}$ operating permits programs would be required. The thresholds EPA proposed would "tailor" these permit programs to limit the number of facilities that would be required to obtain permits and to exclude small businesses and farms, but would still cover nearly $70 \%$ of the largest stationary source GHG emitters, including power plants, refineries, and cement production facilities.

(http://www.epa.gov/NSR/actions.html\#sep09) However, because emissions thresholds for permitting are actually Clean Air Act statutory requirements, it is not clear that EPA has the legal authority to change those thresholds by regulation. (http://blogs.wsj.com/environmentalcapital/2009/12/07/tailor-made-theepa-prepares-to-regulategreenhouse-gas-emissions/tab/article/) Ironically, legal challenges by large GHG emitters will assert that the agency does not have the authority to exclude small ones. For its part, EPA will justify its plan as applying enforcement discretion on the basis of administrative necessity.

There have been a number of efforts by Congress to limit EPA's authority to regulate GHG emissions; however, to-date none have been successful. What ultimately happens in this area is uncertain and unfortunately for the regulated community, uncertainty is about the only thing they can count on right now. Nonetheless, the Idaho Legislature recognizes the importance of planning for potential future regulations and as such, in the Idaho Energy Plan states that "Idaho and Idaho Utilities should prepare for the possibility of federal regulation of greenhouse gas emissions." Knowing what these regulations might look like would make that effort much simpler.

\subsubsection{Western Climate Initiative}

Despite discussions at the national level that often involve "pre-emptive" language, such as in Waxman-Markey, many state and regional GHG cap-and-trade initiatives are still moving forward. The regional cap-and-trade program that is most relevant to Idaho is the Western Climate Initiative (WCI). The WCI, launched in February 2007, is a collaboration of seven U.S. governors and four Canadian Premiers. WCI was created to identify, evaluate, and implement collective and cooperative ways to reduce greenhouse gases in the region, focusing on a market-based cap-and-trade system. The seven partner states are Arizona, California, Montana, New Mexico, Oregon, Utah, and Washington. The four partner Provinces are British Columbia, Manitoba, Ontario, and Quebec. (http://www.westernclimateinitiative.org/)

On September 23, 2008, the WCI released design recommendations for the Regional Cap-and-trade Program. Then on September 30, the WCI released Essential Requirements of Mandatory Reporting for 
the Western Climate Initiative - 2nd Draft. Since then, additional drafts of the Essential Requirements document have been released, and most recently, on July 27, 2010, the WCI released a Design for the WCI Regional Program, which further describes the elements of the program and provides a roadmap for the WCI partner jurisdictions as they implement their regulations. (http://westernclimateinitiative.org/thewci-cap-and-trade-program/program-design)

The WCI set a regional goal to reduce GHG emissions 15\% below 2005 emissions by 2020 . The cap-and-trade program that will be used to reach this regional goal will begin on January 1, 2012. Annual caps are set with three-year compliance periods. The program also has comprehensive sector coverage; it's not just focused on electricity generation. However, some sources won't be covered until the second compliance period (2015). The emission threshold for the program is 25,000 Metric Tons of $\mathrm{CO}_{2} \mathrm{e}$ annually.

WCI is planning on including emissions from transportation fuel combustion for both gasoline and diesel. Coverage of these emissions will begin at the start of the second compliance period (2015). Electricity generation, including electricity generated outside of WCI jurisdictions that is delivered to WCI partners for consumption will also be included in the WCI cap. Industrial sources will be included in the WCI cap as well.

At this point, the WCI is considering allowing a large portion (almost 50\%) of their reductions to come from offsets. Idaho's forest and agriculture industries could both potentially benefit from this.

Idaho is officially an "observer" to the WCI process. Idaho has participated in that capacity at many of the face-to-face meetings as well as on various conference calls. At this point, Idaho has no plans to join WCI as a full partner, but will continue to participate as an observer.

\subsubsection{GHG Reporting and Registries}

There are efforts underway nationally, regionally, and in some individual states to require certain sources of GHG emissions to report their emissions. As was mentioned previously, the Environmental Protection Agency (EPA) recently developed a federal rule that requires certain GHG emission sources across the country to report their emissions. Additionally, many states are planning on going above and beyond what the federal government is doing and are making certain sectors of their economy report their greenhouse gas emissions. This involves developing mandatory reporting rules at the state level. Idaho is not currently moving forward with any mandatory GHG reporting requirements; however, some industries in Idaho will be impacted by the EPA's mandatory reporting rule.

Idaho is a member of The Climate Registry (TCR), a voluntary GHG reporting registry. TCR was established by states, tribes, and provinces in North America as a mechanism to measure GHG

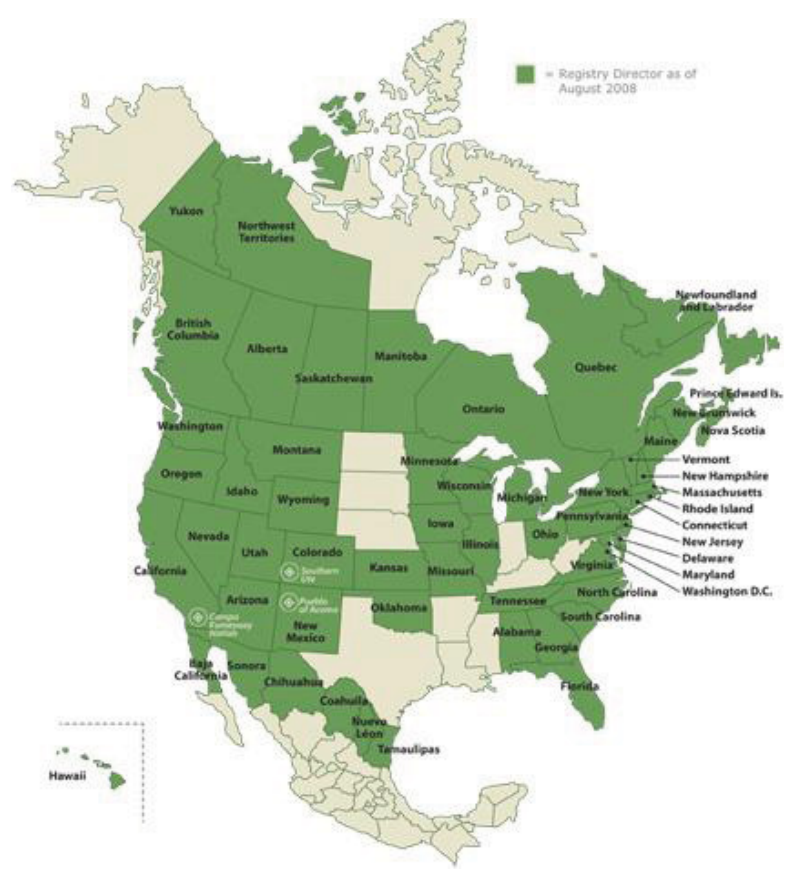

Figure 3. Members of the climate registry. emissions consistently across industry sectors and borders (members are shown in Figure 3). It is a 501(c)(3) nonprofit organization, governed by a board of directors of state, tribal, and provincial 
representatives. The Climate Registry encourages voluntary early actions to increase energy efficiency and decrease GHG emissions.

The Climate Registry accounting infrastructure supports a wide variety of programs that reduce GHG emissions, including voluntary, regulatory, and market-based programs and provides meaningful information to reduce GHG. The Climate Registry establishes consistent, transparent standards throughout North America for businesses and governments to calculate, verify, and publicly report their carbon footprints in a single, unified registry. (http://www.theclimateregistry.org/)

There are many benefits to joining TCR for an organization. Some of these benefits include the following:

- Technical resources for GHG accounting

- Exclusive access to web-based accounting software and extensive technical support simplifies and reduces cost of GHG tracking

- Recognition as an environmental leader

- Participants receive wide recognition as environmental leaders

- Readiness for emission trading

- Many states are now developing GHG emissions trading programs that will be based on TCR standards and data

- Risk management

- Learning to identify emissions sources, understanding your GHG profile, and developing management strategies prepare organizations for assessing and responding to the potential impact of new regulations

- Gain competitive advantage

- Measuring and managing emissions can lead to streamlining business processes and improving efficiency

- Baseline protection

- Establishing a GHG emissions baseline means organizations can document reductions for consideration under any regulatory programs.

The Idaho Department of Environmental Quality (IDEQ) is the first organization in Idaho to join TCR and agree to voluntarily report their carbon emissions. The state will report their emissions for calendar year 2008. This will be a great way for the agency to understand what other companies in Idaho might go through to report their own emissions.

\subsection{Opportunities, Challenges, Needs}

\subsubsection{Opportunities}

There may be some opportunities in the offset market for Idaho (agriculture, forestry, and waste management).

A carbon-constrained economy should result in many new forms of economic development. Some have called it a market transformation. While many concerns have been raised over the negative economic impacts to utilities and traditional industries that emit greenhouse gas emissions, it's also important to look at opportunities that might be presented if a national program moves forward. Idaho is a state that can take advantage of new "green-collar" jobs that might be created and also to produce alternative forms of energy. The demand for both of these will likely increase if a cap-and-trade program goes into effect. There is rightly some skepticism regarding this market transformation, and obviously Idaho should proceed with caution. However, the state should continue to look into this area and prepare 
for potential opportunities. Opposing cap-and-trade and positioning the state to benefit as much as possible if it goes into effect, should not be mutually exclusive.

\subsubsection{Challenges/Needs}

\subsubsection{Resources (Funding and Staff)}

- Idaho currently does not have any full-time positions dedicated to climate change or carbon regulation (there are parts spread throughout various agencies).

- The current state of "carbon regulation" is very dynamic and fluid. Therefore keeping up with it is very resource intensive.

- Staffing requirements to facilitate an improvement in coordination between energy and environmental quality.

- These two areas are handled by two different agencies within state government; however, their responsibilities overlap when it comes to climate change and carbon regulation. Therefore, coordination is paramount.

- Potential problems have been identified within the forestry section of the state's 2008 Greenhouse Gas Inventory Report.

\subsection{Conclusions}

Idaho is a relatively low emitter of GHG. However, Idaho will be impacted to some degree by a regional (WCI) or national greenhouse gas cap-and-trade program. Idaho imports all of its petroleum, refined products, and natural gas as well as much of our electricity from out of state. This means regulations that other states implement (cap-and-trade) will likely impact Idaho. It is critical that the state remains engaged in the discussions and up to speed on where cap-and-trade is heading to avoid detrimental consequences and to take advantage of opportunities.

At this point, the $\mathrm{WCI}$ is considering allowing a large portion of their GHG emission reductions to come from offsets (almost 50\%). Idaho's forest and agricultural industries could both potentially benefit from this. There may be opportunity for carbon sequestration on forest and agricultural land, and opportunities in the area of waste/manure management through the use of technologies such as anaerobic digesters.

Even if WCI is never fully implemented, because of federal pre-emption or other reasons, it is very likely that it will heavily influence the federal program. At the very least, it will give people something to which to compare a federal program. That being said, it currently appears that a federal program is very likely. H.R. 2454 has been passed by the House of Representatives. Additionally, the Senate has indicated that a climate bill will be introduced this fall.

The Climate Registry could also be a key component to either a regional or federal cap-and-trade program. It's important that Idaho continues to participate in TCR. It is also important that more Idaho companies sign up to register their emissions with TCR to stay ahead of the curve.

\subsection{Recommendations}

- Idaho should continue to participate as an observer in the WCI.

- The IDEQ should continue to encourage Idaho companies to join TCR.

- There are many benefits of doing so of which are listed above.

- Create a closer link between the IDEQ and the Office of Energy Resources (OER) as it relates to climate change and carbon regulation. 
- This could include identifying staff members in each agency that act as points of contact and are responsible for coordinating with each other.

- In an ideal situation, additional staff could be hired in each office specifically to address climate change. This is an area that is growing nationally and Idaho could benefit from additional inhouse expertise.

- IDEQ should improve upon the state's current GHG Emissions Inventory.

- IDEQ and the OER should keep track of what other States have done and are doing in emissions reductions and tracking programs (for example, Montana).

- Particularly as it relates to non cap-and trade and/or non-regulatory options (i.e., Low Carbon Fuel Standards).

- IDEQ should coordinate an effort to identify Idaho opportunities to take advantage of potential offsets from various sectors (i.e., forestry, agriculture, waste management, etc.).

- This would need to include other state government agencies and possibly private sector entities such as the Department of Agriculture, the OER, state forestry associations, state dairy/cattle associations, etc.

- IDEQ should explore options for developing a scaled down version of a comprehensive climate action plan.

- Many states have gone through the process of developing a comprehensive climate action plan. Idaho has not. These plans identify the sources of emissions within a state and specific steps that can be taken to reduce them. Many plans identify emission reduction goals or targets for the state. However, the action plan can be tailored for each state's needs

- Clarify state interests and opportunities associated with climate and energy action, particularly in the electricity, transportation, and industrial sectors, so as to be able to respond effectively (pro or con) to federal legislative developments, and (b) maintain close communication with Idaho's Congressional delegation over these issues, particularly on the Senate side.

- This is not a task that any one single state agency could accomplish alone but rather as a group (or subset), such as the ISEA.

\subsubsection{Pros and Cons}

Table 1. Emissions reductions/offsets credits pros and cons.

\begin{tabular}{|c|c|c|}
\hline Options & Pros & Cons \\
\hline $\begin{array}{l}\text { Idaho should continue to } \\
\text { participate as an observer } \\
\text { in the WCI. }\end{array}$ & $\begin{array}{l}\text { - Allows the state to stay up to } \\
\text { speed on the progress of this } \\
\text { initiative. } \\
\text { - Better positioned to identify } \\
\text { opportunities in areas such as } \\
\text { carbon credits. } \\
\text { - Better positioned to identify } \\
\text { potential impacts to Idaho citizens } \\
\text { and utilities located in member } \\
\text { states. }\end{array}$ & $\begin{array}{l}\text { - Requires significant resources } \\
\text { to participate in weekly calls } \\
\text { and periodic meetings. }\end{array}$ \\
\hline $\begin{array}{l}\text { The IDEQ should } \\
\text { continue to encourage } \\
\text { Idaho companies to join } \\
\text { TCR. }\end{array}$ & $\begin{array}{l}\text { - Technical resources for GHG } \\
\text { accounting } \\
\text { - Recognition as an environmental } \\
\text { leader }\end{array}$ & $\begin{array}{l}\text { - Costs can be relatively high } \\
\text { (particularly for the first year). } \\
\text { - Third party verification is } \\
\text { required, which adds } \\
\text { additional expense. }\end{array}$ \\
\hline
\end{tabular}


Table 1. (continued).

\begin{tabular}{|c|c|c|}
\hline Options & Pros & Cons \\
\hline & $\begin{array}{l}\text { - Readiness for emission trading } \\
\text { - Risk management } \\
\text { - Competitive advantage } \\
\text { - Baseline protection }\end{array}$ & $\begin{array}{l}\text { - Uncertainty regarding exactly } \\
\text { how this will interface with } \\
\text { EPA's mandatory reporting } \\
\text { rule. }\end{array}$ \\
\hline $\begin{array}{l}\text { Create a closer link } \\
\text { between the IDEQ and the } \\
\text { OE R as it relates to } \\
\text { climate change and carbon } \\
\text { regulation. }\end{array}$ & $\begin{array}{l}\text { Would allow key staff members } \\
\text { in each agency opportunities to } \\
\text { better coordinate. } \\
\text { - Ideally, new staff could be added } \\
\text { to each office expressly for this } \\
\text { purpose. } \\
\text { More "in-house" expertise for the } \\
\text { state. }\end{array}$ & $\begin{array}{l}\text { - Requires additional resources } \\
\text { (financial and other). }\end{array}$ \\
\hline $\begin{array}{l}\text { IDEQ should improve } \\
\text { upon the state's current } \\
\text { GHG Emissions Inventory }\end{array}$ & $\begin{array}{l}\text { - An accurate inventory is key for } \\
\text { knowing emission sources. } \\
\text { - Knowing emission sources allows } \\
\text { a state to better identify } \\
\text { opportunities and vulnerabilities } \\
\text { when it comes to regulating and } \\
\text { trading carbon. }\end{array}$ & $\begin{array}{l}\text { - Requires financial and } \\
\text { personnel resources. }\end{array}$ \\
\hline $\begin{array}{l}\text { IDEQ and the OER } \\
\text { should keep track of what } \\
\text { other states have done and } \\
\text { are doing in emissions } \\
\text { reductions and tracking } \\
\text { programs (for example, } \\
\text { Montana) }\end{array}$ & $\begin{array}{l}\text { Would help identify non cap-and- } \\
\text { trade and/or non-regulatory } \\
\text { options for the state to consider } \\
\text { (i.e., Low Carbon Fuel } \\
\text { Standards). } \\
\text { - Much more efficient than starting } \\
\text { from scratch. }\end{array}$ & $\begin{array}{l}\text { - Requires resources. } \\
\text { - Any efforts to reduce GHG } \\
\text { can be looked upon negatively } \\
\text { by some. }\end{array}$ \\
\hline $\begin{array}{l}\text { IDEQ should coordinate } \\
\text { an effort to identify Idaho } \\
\text { opportunities to take } \\
\text { advantage of potential } \\
\text { offsets from various } \\
\text { sectors (i.e., forestry, } \\
\text { agriculture, waste } \\
\text { management, etc.) }\end{array}$ & $\begin{array}{l}\text { Possible financial opportunities } \\
\text { for some sectors if carbon offsets } \\
\text { gain value. }\end{array}$ & $\begin{array}{l}\text { - } \text { Requires resources. } \\
\text { - Some entities are not } \\
\text { supportive of the use of offsets } \\
\text { in lieu of actual emission } \\
\text { reductions. } \\
\text { - Some entities are hesitant to } \\
\text { support offsets because it } \\
\text { might infer support for carbon } \\
\text { regulation (i.e., cap-and-trade) }\end{array}$ \\
\hline $\begin{array}{l}\text { IDEQ should explore the } \\
\text { option for developing a } \\
\text { scaled down version of a } \\
\text { comprehensive climate } \\
\text { action plan. }\end{array}$ & $\begin{array}{l}\text { Allows the state to take a } \\
\text { comprehensive look at the issue } \\
\text { of climate change as it } \\
\text { specifically relates to Idaho, } \\
\text { including emission reduction } \\
\text { opportunities, climate adaptation } \\
\text { needs/opportunities, } \\
\text { vulnerabilities to federal } \\
\text { programs, etc. }\end{array}$ & $\begin{array}{l}\text { - This would be relatively } \\
\text { resource intensive because } \\
\text { numerous state agencies and } \\
\text { private companies would need } \\
\text { to be involved. } \\
\text { - This could be perceived as an } \\
\text { attempt to "regulate" carbon } \\
\text { emissions. }\end{array}$ \\
\hline
\end{tabular}


Table 1. (continued).

\begin{tabular}{|c|c|c|}
\hline Options & Pros & Cons \\
\hline & $\begin{array}{l}\text { The state would be much more } \\
\text { informed when it came time to } \\
\text { analysis and possibly weigh in on } \\
\text { federal proposals. }\end{array}$ & \\
\hline $\begin{array}{l}\text { Clarify state interests and } \\
\text { opportunities associated } \\
\text { with climate and energy } \\
\text { action, particularly in the } \\
\text { electricity, transportation, } \\
\text { and industrial sectors. }\end{array}$ & $\begin{array}{l}\text { - Able to respond more effectively } \\
\text { (pro or con) to federal legislative } \\
\text { developments. } \\
\text { - Could be part or focus of option } \\
\text { above. }\end{array}$ & $\begin{array}{l}\text { Would take significant } \\
\text { resources to do it right. }\end{array}$ \\
\hline
\end{tabular}




\section{GEOLOGIC SEQUESTRATION AND CARBON CAPTURE 2.1 Background}

Geologic carbon dioxide sequestration is a process where $\mathrm{CO}_{2}$ is captured at a point source, such as a power plant, compressed and placed into a pipeline and injected through a well into a deep subsurface formation. In a world in which fossil fuel combustion dominates our energy portfolio, large-scale geologic storage of $\mathrm{CO}_{2}$ represents the only viable mechanism to mitigate the effect that $\mathrm{CO}_{2}$ has on the Earth's climate. As a technology, geologic carbon dioxide sequestration is still immature, with only a few small-scale but growing number of carbon sequestration projects underway around the globe.

\subsection{Capture}

Currently the primary focus of CCS activity in the U.S. is large demonstration pilots (one MMT/yr) associated with the Regional Carbon Sequestration Partnerships directed by the National Energy Technology Laboratory (NETL). None of these projects will be completed by the end of FY 2016, making it highly unlikely that the U.S. will adopt a mandatory nationwide CCS program before 2020. Some form of CCS cap-and-trade legislation at both the state and federal level is expected in the next few years (see Section 1).

Today in the U.S., approximately one-half of the $\mathrm{CO}_{2}$ produced from the burning of fossil fuels is emitted from point sources such as power plants, refineries, and cement plants (cement production itself is a large $\mathrm{CO}_{2}$ producer), making them suitable targets for CCS activities. Retrofitting these industrial $\mathrm{CO}_{2}$ sources for $\mathrm{CO}_{2}$ capture and compression is very expensive; in some cases the expense may exceed the cost of replacing the existing facility with a smaller $\mathrm{CO}_{2}$ footprint facility. However, because of the large number of these facilities, replacement is an unlikely short-term solution as the cost of permitting and capitalizing new facilities make the replacement process very slow. In fact, many currently operating facilities are seeking to increase their service life. Taking facilities off line is also an option; however, with continuing increases in energy demand it is neither feasible nor desirable to reduce capacity solely to reduce $\mathrm{CO}_{2}$ emissions. As might be expected, the largest issue facing plants seeking to implement CCS, is the extremely high cost (both in dollars and resources; see Tables 1 and 2) for capturing and compressing $\mathrm{CO}_{2}$. State-of-the-art $\mathrm{CO}_{2}$ capture and compression systems require large amounts of energy to operate; the consumed energy is referred to as parasitic power consumption. Parasitic power consumption is the additional energy required to operate the capture and compression system, and for some types of facilities can be as much as $40 \%$ of the power produced (Table 1). Parasitic power consumption translates into decreased efficiency of the facility and reduced power output that is available to consumers.

Table 2. Parasitic loss due to $\mathrm{CO}_{2}$ capture and compression at various combustion plants.

\begin{tabular}{|l|c|c|c|}
\hline \multicolumn{1}{|c|}{ Power Plant Type } & $\begin{array}{c}\text { Net plant Efficiency } \\
\text { (\%) without CCS }\end{array}$ & $\begin{array}{c}\text { Net Plant Efficiency } \\
\text { (\%) with CCS }\end{array}$ & $\begin{array}{c}\text { Energy Penalty } \\
\text { Added Fuel Input (\%) } \\
\text { per Net kWh Output }\end{array}$ \\
\hline Existing subcritical PC & 33 & 23 & $40 \%$ \\
\hline $\begin{array}{l}\text { New Super Critical (SPPC) } \\
\text { post-combustion capture }\end{array}$ & 40 & 31 & $30 \%$ \\
\hline $\begin{array}{l}\text { New Super Critical + } \\
\text { oxycombustion (SCPC-O) } \\
\text { Post-combustion }\end{array}$ & 40 & 32 & $25 \%$ \\
\hline $\begin{array}{l}\text { Coal Gasification (IGCC) } \\
\text { pre-combustion capture }\end{array}$ & 40 & 34 & $19 \%$ \\
\hline $\begin{array}{l}\text { Natural Gas (NGCC) } \\
\text { post-combustion capture }\end{array}$ & 50 & 43 & $16 \%$ \\
\hline
\end{tabular}


Lower efficiencies also requires that more carbon-based fuel is combusted in order to deliver the same thermal output, resulting in a proportional increases in the resource mining impact, plant footprint, and waste generation. Additionally and perhaps most importantly for the arid western U.S., is that largescale implementation of $\mathrm{CO}_{2}$ capture and compression will significantly increase consumptive water demands throughout the process. Ultimately, all of these impacts will be manifest as increased cost to consumers. Table 2 contains a summary of the estimated per ton costs for CCS. Clearly, these costs will have a significant impact on those who consume power. It should be noted that the costs associated with capture are much greater than the costs associated with transportation and storage. These costs will be especially burdensome to states like Idaho, where the costs of CCS cannot be offset by revenues generated from excise taxes on coal, oil, natural gas, or power generation like they can in carbon resource rich states (e.g. Montana, Utah, and Wyoming).

Table 3. Capture and compression cost for various combustion technologies.

\begin{tabular}{|l|l|}
\hline \multicolumn{1}{|c|}{ CCS System Component } & \multicolumn{1}{c|}{ Cost Range (U.S. dollars) } \\
\hline Capture: fossil fuel power plant & $\$ 20-\$ 95 /$ ton net CO2 captured \\
\hline $\begin{array}{l}\text { Capture: hydrogen and ammonia production or } \\
\text { gas-processing plant }\end{array}$ & $\$ 5-\$ 70 /$ ton net CO2 captured \\
\hline $\begin{array}{l}\text { Capture: other industrial sources (content, } \\
\text { refineries, etc.) }\end{array}$ & $\$ 30-\$ 145 /$ ton net CO2 captured \\
\hline Transport: pipeline & $\$ 1-\$ 10 /$ ton net CO2 captured \\
\hline Storage: geologic formations & $\$ 0.50-\$ 10 /$ ton net injected \\
\hline
\end{tabular}

\subsection{Current Status}

CCS activities in the state of Idaho have been ongoing since early 2003; in large part, these activities have been conducted through membership in the Big Sky Regional Carbon Sequestration Partnership (BSP) and through research conducted at the Center for Advanced Energy Studies (CAES). To date, geologic sequestration-related activities have been conducted by the Idaho National Laboratory (INL), the University of Idaho (U of I), Idaho State University (ISU), and Boise State University (BSU). With the exception of BSU (participated in Phase I), these organizations participated in the Partnerships Idaho specific activities in Phase I and II. INL continues to participate in the Partnerships Phase III pilot which is largely being conducted in neighboring states. The activities of the Partnership in Idaho have primarily been associated with $\mathrm{CO}_{2}$ source mapping and characterization of sequestration potential of the basalt formations of the Eastern Snake River Plain and the Columbia River Plateau. In addition, INL and the U of I have conducted a significant amount of public outreach and education in Idaho through CAES. The most prominent of these activities is a workshop held in August 2008 in Boise, Idaho and a series of CAES Carbon Management Initiative (CMI) workshops at ISU, U of I, and BSU held in late 2010. The August 2008 workshop attendees included members of the state legislature, IDEQ, state universities, INL, and the Idaho OER, to name a few. The results of this workshop are being processed by CAES, and will be used to organize the next series of workshops in cooperation with the CIT. In addition to the activities of the BSP, Idaho has also established two working groups to assist with CCS activities in the state:

- The Idaho Governor's Carbon Sequestration Advisory Committee

- Idaho Carbon Issues Taskforce, part of the - Idaho Strategic Energy Alliance (ISEA), for which this document is being written.

These two committees have historically been directed through the Idaho Soil Conservation Commission (ISCC), and have been largely populated by terrestrial sequestration experts, although 
geologic sequestration interests have been represented by a member scientist from INL, and recentlyadded faculty from ISU and U of I. Recently, Travis McLing from INL/CAES has taken over as the lead for CIT His background in geologic CCS should help strengthen the CIT's position in this area.

Starting in 2007, CAES began the funding of a multiyear multidisciplinary research project to investigate the sequestration potential of the basalt formations located in the Eastern Snake River Plain. This project combines geologic characterization and reactive transport modeling with an economic risk assessment model to provide the basis for a decision framework should CCS activities move forward in the future.

\subsection{Opportunities, Challenges, Needs}

Because CCS is only viable for point source emitters of $\mathrm{CO}_{2}$, the advancement of geologic storage will be intimately connected with the development of new $\mathrm{CO}_{2}$-emitting facilities. The complex geology of Idaho and the limited availability of deep sedimentary basin require that unconventional CCS opportunities be explored. However, this limitation is in part the result of almost non-existent characterization of deep geologic formation in the state. The lack of characterization, and the poor understanding of associated storage, represents a significant level of project risk for the siting of $\mathrm{CO}_{2}$-emitting facilities. Further limiting the development of CCS in the state is the lack of a unified regulatory structure for geologic storage. To address the limitation, a systematic, substantial, and sustained characterization of the state's potential, coupled with a well-defined regulatory environment, is needed in order to reduce uncertainty regarding geologic CCS potential.

The current limited characterization data suggests that available CCS options will be restricted to reactive basalts of the Snake River Plain of Southern Idaho. However, the implementation of a CCS project in basalts will require significant site characterization and background studies. This differs from sedimentary basin targets that have had extensive deep evaluation as a result of energy exploration and production. Additionally, pending federal regulation that may limit geologic storage of $\mathrm{CO}_{2}$ to formations with fluid containing greater than $10,000 \mathrm{ppm}$ dissolved solids may severely limit the siting options for projects. However, the challenges associated with unconventional storage provide an opportunity for Idaho to take the lead in developing general methodologies for utilizing unconventional targets, transferring these methodologies to other regions in the country, and working with limited conventional potential. To realize this opportunity, focused research and development programs on key aspects of unconventional storage are needed.

\subsection{Conclusions}

Because so little of Idaho's energy consumption is from point sources produced within the state, most of its CCS obligations in the near term will not be carried out within our borders. Any future federal capand-trade program will require neighboring states that export energy to Idaho to develop carbon mitigation plans. The cost of those mitigation plans will be passed on to consumers in the form of increased cost for liquid fuel, electricity, natural gas, etc. It is expected that Idaho's energy exporting neighbors will be more immune than Idaho from the cost of carbon mitigation, as costs in those states can be offset by production excise taxes and through revenue generated by the sale of carbon resources. Therefore, it is expected that cap-and-trade will have a more pronounced impact on Idaho's economy than that of its neighbors. The ability of Idaho to compete with these states to attract new industry requires the development of a strategic statewide business plan that accounts for a carbon-constrained economy. ISEA should recommend to the Idaho OER that CAES and its member organizations be used as a resource to assist the state with its carbon management issues. The goal of this initiative is to prepare the state of Idaho and the CAES partners to take advantage of the research, education, and policy opportunities presented by an emerging carbon-constrained economy and its associated regulatory structure, and to minimize the impact of the aforementioned constraints. An additional goal is to position CAES to provide support to the state of Idaho's OER on carbon management issues. CAES will accomplish this goal by 
working closely with the ISEA and the OER to develop a practical Carbon Management Plan that addresses the unique nature of Idaho's carbon issues.

The potential for geologic storage in the state of Idaho is currently limited by a lack of information regarding the state's deep subsurface. Existing data suggest that $\mathrm{CO}_{2}$ storage will likely occur in small, unconventional targets. Pending federal regulation may further limit these options. However, additional characterization of the state's potential may result in the identification of currently unknown $\mathrm{CO}_{2}$ storage locations and potential.

\subsection{Recommendations}

- Development of regulatory framework for geologic CCS.

- CAES should continue to lead education and outreach as well as integrated involvement of effected stakeholders in a public outreach setting.

- ISEA will lead an effort to assess the impact of a federal cap-and-trade program on air, water, and land use in Idaho. (June 2009)

- Collaborate with states that export energy to Idaho to determine the impact that CCS activities will have on Idaho's economy. Specifically, the CMI will target the lead energy research entities in Montana, Wyoming, and Utah, which include:

- University of Wyoming's School of Energy Resources (SER): CMI will establish a working relationship with SER through CAES.

- Montana State University - BSP: CMI, through CAES will continue to work closely with the Partnership's Economic and Regulatory working groups.

- Utah State University's Bingham Entrepreneurship and Energy Research Center (BEERC) and University of Utah's Energy and Geoscience Institute.

- CMI will assist CAES in supporting the Idaho OER's carbon management issues.

- Characterization of statewide geologic storage potential.

- ISEA will recommend Idaho's legislative bodies that they should charge the Idaho Geological Survey with leading a coordinated effort to characterizes Idaho's geologic carbon sequestration potential. (January 2010)

- This effort should be coordinated such that geologic sequestration opportunities are matched to likely future economic development.

- Develop technologies required for unconventional CCS.

- ISEA should engage the four main research entities of the state (BSU, ISU, U of I, and INL) through CAES to conduct an evaluation of unconventional CCS potential in the state. 


\subsubsection{Pros and Cons}

Table 4. Geologic carbon sequestration summary pros and cons.

\begin{tabular}{|c|c|c|}
\hline Recommendation & Pros & Cons \\
\hline $\begin{array}{l}\text { Develop a regulatory framework } \\
\text { for geologic sequestration in Idaho }\end{array}$ & $\begin{array}{l}\text { This will ensure that the state } \\
\text { of Idaho is prepared should } \\
\text { an industrial entity seek to } \\
\text { locate to the state and desire } \\
\text { to store } \mathrm{CO}_{2} \text {. }\end{array}$ & $\begin{array}{l}\text { - Would require additional } \\
\text { resources for state } \\
\text { regulatory entities already } \\
\text { experiencing budget } \\
\text { shortfalls. }\end{array}$ \\
\hline $\begin{array}{l}\text { CAES should continue to lead } \\
\text { education and outreach as well as } \\
\text { integrated involvement of effected } \\
\text { stakeholders in a public outreach } \\
\text { setting. }\end{array}$ & $\begin{array}{l}\text { - Would allow for a broad- } \\
\text { based response to the } \\
\text { educational needs in the state } \\
\text { with respect to policy and } \\
\text { CCS issues. } \\
\text { - Would continue to strengthen } \\
\text { the working relationship } \\
\text { between the CAES member } \\
\text { organizations, the ISEA, and } \\
\text { the OER. }\end{array}$ & $\begin{array}{l}\text { - CAES would need to } \\
\text { provide the four CAES } \\
\text { member institutions with } \\
\text { resources and } \\
\text { management oversight to } \\
\text { carry out this } \\
\text { recommendation. It is } \\
\text { unclear if this type of } \\
\text { activity could be } \\
\text { supported in the manner } \\
\text { necessary by CAES. }\end{array}$ \\
\hline $\begin{array}{l}\text { ISEA will lead an effort to assess } \\
\text { the impact of a federal cap-and- } \\
\text { trade program on air, water, and } \\
\text { land use in Idaho. }\end{array}$ & $\begin{array}{l}\text { The experts that sit on this } \\
\text { Taskforce are uniquely } \\
\text { qualified for this activity and } \\
\text { could easily carry it out. } \\
\text { - Would fulfill the charter of } \\
\text { the Carbon Issues Task Force. }\end{array}$ & $\begin{array}{l}\text { - Most of the ISEA CIT } \\
\text { members serve on a } \\
\text { volunteer basis, with their } \\
\text { time already at a } \\
\text { premium. } \\
\text { - Federal cap-and-trade } \\
\text { legislation and regulation } \\
\text { continues to be a moving } \\
\text { target and it would be } \\
\text { difficult to come to any } \\
\text { conclusion or } \\
\text { recommendations until } \\
\text { that situation changes. }\end{array}$ \\
\hline $\begin{array}{l}\text { Collaborate with states that export } \\
\text { energy to Idaho to determine the } \\
\text { impact CCS activities will have on } \\
\text { Idaho's economy. }\end{array}$ & $\begin{array}{l}\text { Would allow Idaho to } \\
\text { develop a closer working } \\
\text { relationship with its } \\
\text { neighboring states, which } \\
\text { happen to provide Idaho with } \\
\text { the vast majority of its } \\
\text { consumable energy resources. } \\
\text { - Idaho could benefit from } \\
\text { associating with neighboring } \\
\text { states that are much further } \\
\text { down the CCS road. }\end{array}$ & $\begin{array}{l}\text { Would require a } \\
\text { significant commitment } \\
\text { of time and energy from } \\
\text { the ISEA and specifically } \\
\text { the CIT. It is unclear } \\
\text { where the resources for } \\
\text { this activity would come } \\
\text { from. }\end{array}$ \\
\hline $\begin{array}{l}\text { CMI will assist CAES in } \\
\text { supporting the Idaho OER's carbon } \\
\text { management issues. }\end{array}$ & $\begin{array}{l}\text { - Idaho scientists are uniquely } \\
\text { qualified to work on this } \\
\text { capacity assessment. }\end{array}$ & \\
\hline
\end{tabular}


Table 4. (continued).

\begin{tabular}{|l|l|l|}
\hline \multicolumn{1}{|c|}{ Recommendation } & \multicolumn{1}{c|}{ Pros } & \multicolumn{1}{c|}{ Cons } \\
\hline $\begin{array}{l}\text { Develop technologies required for } \\
\text { unconventional CCS. }\end{array}$ & $\begin{array}{l}\text { - Idaho would certainly benefit } \\
\text { from this development as its } \\
\text { carbon storage options are } \\
\text { terrestrially orientated or are } \\
\text { by definition geologically } \\
\text { unconventional. }\end{array}$ & $\begin{array}{l}\text { - Implementing this } \\
\text { recommendation would } \\
\text { be very expensive and } \\
\text { given the lack of } \\
\text { movement on federal } \\
\text { carbon legislation, return } \\
\text { on investment is not } \\
\text { certain. }\end{array}$ \\
\hline $\begin{array}{l}\text { Characterization of statewide } \\
\text { geologic storage potential. }\end{array}$ & $\begin{array}{l}\text { The state would gain valuable } \\
\text { information regarding the } \\
\text { deep geologic terrains } \\
\text { contained within its borders. } \\
\text { Additionally, it would } \\
\text { provide an avenue to evaluate } \\
\text { the geothermal potential of } \\
\text { these portions of the state }\end{array}$ & $\begin{array}{l}\text { The cost to conduct such } \\
\text { a comprehensive study } \\
\text { would be expensive and } \\
\text { time consuming }\end{array}$ \\
\hline
\end{tabular}




\section{FORESTRY \\ 3.1 Background}

Forests actively remove $\mathrm{CO}_{2}$ from the atmosphere and store it on-site in forest carbon "pools" and off-site in wood products and landfills. Using wood products as building materials that substitute for steel and cement, and as a renewable energy feedstock, will keep fossil fuels in the ground and thereby avoid emissions from fossil fuel burning. Information regarding forestry energy issues can be found in the ISEA Forestry/Biomass Taskforce Report at http://www.energy.idaho.gov/energyalliance/taskforce.htm.

\subsection{Current Status}

Idaho's forests cover $40.5 \%$ of the state, and their inability to prevent and reduce $\mathrm{CO}_{2}$ emissions is an issue, especially on National Forest System lands that comprise $76 \%$ of Idaho's forest lands. A preliminary GHG inventory report prepared in May 2008 for the IDEQ by the Center for Climate Strategies (CCS) stated that "Forestlands are net sources of $\mathrm{CO}_{2}$ in Idaho" and in 2005 contributed 10\% of the State's GHG emissions (see pie chart figure 1) in Emissions Inventory section of this report. Across the U.S. however, forests capture and store (i.e., "sequester") carbon, and in 2005 acted as a net carbon sink for more than $10 \%$ of all human-caused $\mathrm{CO}_{2}$ emissions in the nation.

Despite huge quantities of GHG emissions from wildfires, Idaho's forests are a net sink for atmospheric carbon. (See Appendix B for references in support of this and other claims.) Until the two differing source-or-sink conclusions are reconciled, rather than the conclusive pie chart format presented in the Emissions Inventory section, a tabular presentation (Appendix Table F-1) leaves the forest sourceor-sink question unsettled while presenting emissions data from all other sectors. The table also corrects an error in the pie chart regarding fossil fuel use.

Idaho's forests in 2005 added a net total of $19.5 \mathrm{MMt} \mathrm{CO}_{2} \mathrm{e}$ in newly sequestered carbon (Appendix Table F-3). Wildfires in 2005 were the single largest source of GHG emissions in the state, with 18.4 $\mathrm{MMt} \mathrm{CO}_{2}$ and another 1.3 $\mathrm{MMt} \mathrm{CO}_{2} \mathrm{e}$ in the form of methane and nitrous oxide. Wildfire emissions were equivalent to putting 3.6 million cars on Idaho's highways for a year. However, the amount of atmospheric carbon captured by forest growth greatly exceeded wildfire emissions. All sources of fossil fuel combustion in the state emitted 22.1 $\mathrm{MMt} \mathrm{CO}_{2} \mathrm{e}$ in 2005 (Appendix Table F-1). The net effect was that Idaho's forests offset $88 \%$ of all fossil fuel combustion emissions in the state, or $60 \%$ of all GHG emissions.

In 2006 Idaho's forests experienced enormous wildfires with emissions equal to $160 \%$ of emissions from all fossil fuel-burning activities, to putting 6.4 million cars on Idaho's highways for a year, or 2.8 million more cars than wildfires in 2005. The greater extent of wildfires in 2006 reduced the forest carbon sink function considerably, but nevertheless tree growth provided a net carbon sink function of 3.8 $\mathrm{MMt} \mathrm{CO}_{2} \mathrm{e}$, which offset $17 \%$ of all fossil fuel-burning emissions in the state (Appendix Table F-3).

\subsection{Opportunities, Challenges, Needs}

The largest opportunity to enhance the carbon sequestration potential of Idaho's forests is to reduce the potential for large wildfires by reducing the amount of hazardous fuels in at-risk areas. The challenge to doing this is that almost all these areas are on National Forest System lands administered by the USFS in ten national forests throughout the state, and the agency operates under a complex web of planning and environmental laws that provide citizens with opportunities to challenge managers' decisions on procedural as well as substantive grounds. Furthermore, about half of the agency's budget now is diverted to fire suppression efforts, which reduces budgets for planned pre-fire fuels reduction projects.

Earlier efforts by the state of Idaho to deal with the gridlocked decision process on national forests have been fruitless. Today removals of hazardous fuels and marketable timber products from Idaho's national forests are at the lowest level since 1947. A sustainable solution must be ecologically and 
environmentally sensible, economically feasible, and socially acceptable. Professional foresters employed by the U.S. Forest Service have demonstrated that they can remove timber from the forest without irreparable damage to ecosystems and the environment. Economic feasibility requires the removal of merchantable-size timber with commercial value along with smaller low-value trees that create much of the fire hazard problem. The largest challenge, and the most urgent, is to design socially acceptable projects and have durable decisions that allow managers to implement projects on the ground.

Idaho cannot and should not do this alone, because it is a West-wide problem. Idaho still has an infrastructure that can do the work needed in the woods and modern efficient mills that can turn timber into useful consumer products. Many forestry organizations are poised to help with ongoing efforts, including the Society of American Foresters, the Western Governors' Association's Forest Health Advisory Committee, and the Western Forestry Leadership Coalition. Ultimately, though, under the existing federal laws, conditions in Idaho's national forests cannot be improved without the consent of a representative and inclusive set of Idaho's citizens who support the sustainable management of our national forests in all dimensions.

\subsection{Conclusions}

Some of the ten conclusions drawn in the Carbon Sequestration on Idaho Agriculture and Forest Lands report by the Idaho Carbon Sequestration Advisory Committee in 2003 remain relevant today (Appendix B Part 5 lists these recommendations and their status today). The state of Idaho has significant interests in the management of the national forests that comprise $39 \%$ of the state, including 16.4 million acres of forest lands. The U.S. Bureau of Land Management controls another 21\% of the state, including almost one million acres of forest lands. These agencies are governed by U.S. planning laws, including the National Environmental Policy Act (NEPA), National Forest Management Act, and Federal Land Policy and Management Act, as well as the Endangered Species Act. Although the precedence of federal legislation precludes any state control over federal forest lands - whether for sequestering carbon, reducing wildfire risks, or any other objective - the interests of several states, particularly in concert, may be able to exert needed influences.

The state of Idaho has economic and regulatory interests in state and private lands, including tribal forests, functioning as carbon pools; some attention should be focused on the potential and socially appropriate exercise of those interests. Strategies for improving the carbon sequestration ability of these forests include enhancing tree growth using a variety of silvicultural (the art and science of tending and regenerating forest vegetation) practices that will vary depending on forest stand conditions. In addition, durable wood products manufactured in Idaho substitute for energy-intensive steel and concrete building materials, thus avoiding fossil fuel emissions by keeping fossil fuels in the ground. Wood bioenergy also displaces fossil fuel use.

Timber harvested to provide raw material for wood and paper products creates substantial quantities of logging slash. The Idaho Forest Practices Act requires disposal of these forest residues, and the cheapest method is piling and burning. This activity generates $3.1 \mathrm{MMt} \mathrm{CO}_{2} \mathrm{e}$ per year, equal to putting 563,000 more cars on the highway. As detailed in the ISEA Forestry Task Force report, logging residues represent an opportunity to turn waste material that generates air pollution into a renewable energy resource that substitutes for fossil fuel energy and reduces air pollution considerably. The state of Idaho has an interest in coordinating federal, state, and tribal forest ownerships in the establishment of a mutually beneficial and cohesive carbon management policy.

\subsection{Recommendations}

There are several actionable options for increasing the carbon sequestration potential of Idaho's forests. Because of the close relationship of carbon emissions and energy production, these options will create local opportunities to produce energy as well as improve the global carbon balance.

Responsibilities for initiating or implementing the recommended actions are included in the discussion 
below. A summary table of these recommended options appears in the Summary section of this report, with a list of "pros and cons" for each.

- Resolve whether Idaho's forests are a net source of GHG emissions or a net sink for atmospheric carbon.

- Responsibility for resolving this issue has been assigned to the IDEQ with its charge to conduct and report a greenhouse gas inventory in the state. The crux of the issue is the choice of GHG inventory baseline data for 1990 used for the widely accepted carbon stock change method of GHG emissions assessment. The issue is covered in detail in Appendix B. The consulting firm, Center for Climate Strategies (CCS, engaged by the DEQ to conduct the state's GHG inventory, uses a set of data that leads to the conclusion that Idaho's forests are a net source of emissions. The CCS is influenced by their use of the U.S. Forest Service Carbon Calculation Tool model used to generate forest carbon pool data. Embedded in this model is 1990 baseline data that likely overstates forest carbon stocks. Better data are available. The USFS has created four data sets that could be used to determine the role of forests in the Idaho greenhouse gas inventory (see Appendix Table F-2). The ISEA Forestry Task Force has pledged to help DEQ determine whether Idaho's forests are a source or sink, has located the source of the problem, and has enlisted a Forest Service scientist to help resolve this issue.

- Develop and adopt a GHG inventory protocol that includes reserved forest lands, is sensitive to measured changes in dead tree volume and wildfire extent.

- Data on these carbon stock change factors only recently became available. They provide a more accurate accounting of forest carbon sequestration and emissions. These tasks would fall under DEQ's assigned responsibilities for maintaining a greenhouse gas inventory.

- Reserved forest lands (wilderness areas). Until 2008, the USFS did not publish inventory data on forest growing stock in wilderness areas and other reserved forest lands. Of the 21.4 million acres of forest lands in Idaho, 3.2 million acres are reserved, almost all is National Forest System lands that are in the National Wilderness Preservation System. The method used in the preliminary 2005 GHG inventory for Idaho by CCS for the DEQ does not include wilderness areas and other reserved forest lands. The USFS now has a Forest Inventory Data Online (FIDO) database that provides this data, and a simple formula can be used to convert forest growing stock inventory to on-site carbon pool stocks (see Appendix Sidebar B-1).

- $\quad$ Sound dead wood. The CCS modeled data understate the substantial measured increase in dead wood over the past decade. Dead wood is stored carbon, and not including large changes in dead wood inventory gives a misleading reading on the source-or-sink question. The dead wood increase between 1997 and 2007 is substantial enough so that when added to any set of live growing stock data change will indicate that Idaho's forests have functioned as a sink since 1990 (Appendix Table F-2).

- Wildfire emissions. Before 2007, data on annual emissions from wildfires did not exist. The National Center for Atmospheric Research has produced useful data, and the carbon stock change protocols for forestry GHG emissions could be modified. In an average year in the period from 2002 to 2006, Idaho wildfires emitted $\mathrm{CO}_{2}$ equivalent to $89 \%$ of fossil fuel combustion; in $2006 \mathrm{CO}_{2}$ emissions were $160 \%$ of fossil fuel-burning emissions (documented in Appendix B).

- Support creation of a full range of forestry offsets under all carbon emissions credit trading scheme(s) that do or will affect Idaho forest landowners, including bioenergy.

- To some extent this is an executive branch responsibility because the DEQ represents Idaho interests in the developing WCI. However, the potential for a federal emissions trading scheme looms on the near horizon, and the ability of Idaho to influence that rests primarily with our elected congressional delegation. 
- The Chicago Climate Exchange (CCX) has emerged as a trading platform for voluntary carbon emissions credits for forestry offset projects that include afforestation, sustainable forest management, and durable wood products. The CCX does not recognize as an emissions offset activity the use of wood to produce bioenergy, and neither do merging regional and national programs. Allowing wood bioenergy offset credits would create incentives for wood bioenergy development, and as biogenic emissions from wood replace anthropogenic emissions from fossil fuels, the global carbon balance will be improved because for every unit of biomass burned for energy, a like unit of fossil fuels stays underground. This relationship assumes that the biomass will regrow, which creates a need for sustainable forest management practices and third-party certification.

- Develop quantitative models of carbon response in Idaho's forest types to various silvicultural practices and use them to identify best management practices that foresters can implement.

- This is an option recommended by the Idaho Carbon Sequestration Advisory Committee in 2003 and not carried out (see Appendix B Part 5). It is a responsibility of the executive branch, most likely the state's forestry agency, the Idaho Department of Lands. According to the USFS, northern Idaho's forests are among the most productive in the nation. Current regional protocols developed by the USFS understate the carbon sequestration ability of these forests, averaging them with lowproductivity, dry-site forests on the continental divide to develop a regional average used in carbon models. In effect this cheats owners of the most productive forests and rewards those whose lands are generally not actively managed due to low productivity. In addition, best management practices can help foresters become better accustomed to providing new ecosystem services, especially carbon sequestration.

- Increase USFS budget for restoration, especially projects with restoration-based reduction of hazardous fuels designed to reduce wildfire risks.

- This is one of the options recommended by the ISEA Forestry Task Force in its report. This depends on action by Idaho's elected congressional delegation, perhaps with urging by the Idaho Legislature and the Governor. As this is a West-wide issue, the Western Governors' Association could perhaps play a role.

- Repeating this recommendation from the ISEA task force report is done to recognize the interrelationship of energy resources and human-caused carbon emissions. This report emphasizes wildfire, which is in effect the antithesis of carbon sequestration. Wildfire releases the carbon stored in vegetation into the atmosphere in the same way that burning fossil fuels releases stored carbon. The difference is that vegetation can be regrown. Sometimes, though, it is not and deforestation worldwide accounts for about $20 \%$ of anthropogenic GHG emissions. High tree mortality rates and increasing volumes of dead timber illustrate that Idaho's forest conditions can be improved (see Appendix Table F-2).

- Provide public education and outreach venues, such as workshops and community-based consensusbuilding efforts that focus on the positive role and benefits provided by actively managing forests to sequester carbon on-site with best management practices and off-site in durable forest products and bioenergy facilities that substitute for fossil fuel use.

- Action on this requires financial support as well as workshop organizers. Several state agencies already do comparable workshop organizing tasks, including the U of I's Cooperative Extension Service and the ISCC. CAES, through its Energy Policy Institute could also play a role because carbon management is closely interrelated with energy production.

- Idaho's efforts have not included working directly with USFS managers to develop local support needed to implement hazardous fuel reduction projects. Such efforts may be aided if one person in state government were given a state-wide responsibility to work closely with Forest Service managers and community-based interest groups. This person could work side-by-side with the Idaho National 
Fire Plan Coordinator, a Forest Service employee on loan to the Idaho Department of Lands, but work specifically on the design of socially acceptable federal land management projects. Several local collaborative efforts are ongoing in Idaho communities, but have no support or coordination from the state. For example, whether the consensus-building effort in Salmon is learning from a similar effort in Coeur d'Alene, and vice versa, though unknown, is unlikely. The success of these communitybased collaborative efforts could perhaps be increased with state government involvement and coordination.

\subsubsection{Pros and cons}

Table 5. Forestry carbon issues options summary_pros and cons.

\begin{tabular}{|c|c|c|}
\hline Options & Pros & Cons \\
\hline $\begin{array}{l}\text { Resolve whether Idaho's } \\
\text { forests are a net source of } \\
\text { emissions or a net sink for } \\
\text { atmospheric carbon. }\end{array}$ & $\begin{array}{l}\text { - Answers the question, are Idaho's } \\
\text { forests part of the problem or part } \\
\text { of the solution? } \\
\text { - Identify opportunities to improve } \\
\text { forest conditions and renewable } \\
\text { energy feedstocks. }\end{array}$ & $\begin{array}{l}\text { - Requires concerted effort to } \\
\text { develop consensus between the } \\
\text { USFS, DEQ and their } \\
\text { consulting firm, and the ISEA } \\
\text { Forestry Task Force. }\end{array}$ \\
\hline $\begin{array}{l}\text { Develop GHG inventory } \\
\text { protocol to include } \\
\text { wilderness areas and } \\
\text { measure changes in } \\
\text { wildfire extent and dead } \\
\text { wood. }\end{array}$ & $\begin{array}{l}\text { Helps answer the source-or-sink, } \\
\text { problem-or-solution questions } \\
\text { above } \\
\text { Includes all forest lands in the } \\
\text { state } \\
\text { Includes explicitly the largest } \\
\text { source of GHG emissions in the } \\
\text { state-wildfires. }\end{array}$ & $\begin{array}{l}\text { - Requires concerted effort to } \\
\text { develop consensus between the } \\
\text { USFS, DEQ and their } \\
\text { consulting firm CCS, and the } \\
\text { ISEA Forestry Task Force. }\end{array}$ \\
\hline $\begin{array}{l}\text { Support carbon credits for } \\
\text { a full range of forestry } \\
\text { offset opportunities, } \\
\text { including bioenergy. }\end{array}$ & $\begin{array}{l}\text { - } \begin{array}{l}\text { Provides incentive to practice } \\
\text { sustainable forest management }\end{array} \\
\text { - } \begin{array}{l}\text { Provides incentive for renewable } \\
\text { energy feedstock production }\end{array} \\
\text { - Generates local employment } \\
\text { opportunities. }\end{array}$ & $\begin{array}{l}\text { - Requires sustainable forestry } \\
\text { certification and related } \\
\text { expenses } \\
\text { - Some people do not believe } \\
\text { forestry offset projects other } \\
\text { than afforestation are } \\
\text { appropriate means for reducing } \\
\text { GHG emissions. }\end{array}$ \\
\hline $\begin{array}{l}\text { Develop quantitative } \\
\text { models of forest carbon } \\
\text { response and identify } \\
\text { carbon best management } \\
\text { practices. }\end{array}$ & $\begin{array}{l}\text { Defines relationship between land } \\
\text { management actions and carbon } \\
\text { sequestration } \\
\text { Reflects and rewards } \\
\text { Idaho-specific conditions instead } \\
\text { of regional average } \\
\text { - Motivates sustainable forestry } \\
\text { practice. }\end{array}$ & $\begin{array}{l}\text { - Requires financial resources to } \\
\text { support research. }\end{array}$ \\
\hline
\end{tabular}


Table 5. (continued).

\begin{tabular}{|l|l|l|}
\hline \multicolumn{1}{|c|}{ Options } & \multicolumn{1}{|c|}{ Pros } & \multicolumn{1}{c|}{ Cons } \\
\hline $\begin{array}{l}\text { Increase USFS budget for } \\
\text { restoration and hazardous } \\
\text { fuel reduction. }\end{array}$ & $\bullet \begin{array}{l}\text { Improves natural environment } \\
\text { Reduces wildfire hazards } \\
\text { Increases bioenergy feedstock } \\
\text { supply } \\
\text { Redirects slash disposal resulting } \\
\text { in fewer open-burning emissions. }\end{array}$ & $\begin{array}{l}\text { Requires funding for } \\
\text { environmental analysis in } \\
\text { addition to on-the-ground } \\
\text { project activities. }\end{array}$ \\
\hline $\begin{array}{l}\text { Provide outreach efforts to } \\
\text { develop support for active } \\
\text { forest management. }\end{array}$ & $\begin{array}{l}\text { Increases knowledge of benefits } \\
\text { of managing forests to sequester } \\
\text { carbon and provide bioenergy } \\
\text { feedstocks } \\
\text { Generates support for active } \\
\text { forest management of national } \\
\text { forests. }\end{array}$ & $\begin{array}{l}\text { Requires resources } \\
\text { Some people will not support } \\
\text { active management of national } \\
\text { forests for any reason. }\end{array}$ \\
\hline
\end{tabular}




\section{AGRICULTURE \\ 4.1 Background}

The agricultural community in Idaho has been proactively involved with carbon sequestration efforts since 2002.

Idaho Code 22-5103, enacted on July 1, 2002, instructed the Idaho Soil Conservation Commission (ISCC) to prepare a report exploring the potential for carbon sequestration on agricultural and private, non-industrial forestlands. In addition, this legislation called for the appointment of a 19-member Carbon Sequestration Advisory Committee to be chaired by ISCC.

The first task given to the Committee by the Legislature was to produce a report to evaluate the potential for carbon sequestration in Idaho and carbon trading opportunities for agriculture and forestry. In February 2003, a document entitled Carbon Sequestration on Idaho Agricultural and Forest Lands was completed and submitted to the Legislature. This report describes Idaho's great potential for agricultural carbon sequestration, other greenhouse gas emission reductions, and ancillary benefits related to soil and water conservation.

In addition, the report included recommendations to guide the Advisory Committee. The recommendations are listed as follows:

- The Carbon Sequestration Advisory Committee continue monitoring ongoing developments, facilitate economic analysis, facilitate research activities, and provide information to landowners and operators

- Initiate carbon market pilot projects

- Improve landowners' understanding of carbon sequestration and climate change

- Enhance carbon sequestration research relevant to Idaho

- Complete carbon sequestration and GHG baseline analysis to prepare for future carbon sequestration markets

- Evaluate potential economic benefits to Idaho landowners and the state participation in carbon markets

- Explore the possibility of requiring carbon trading participants to register their trades with the state

- Explore avenues to increase carbon sequestration in Idaho.

Also in 2002, the Pacific Northwest Direct Seed Association (PNDSA), a grower-based organization committed to increasing direct-seed farming in the Pacific Northwest, pioneered the first carbon leasing program in Idaho and Washington. The PNDSA negotiated an agreement with a company called Entergy that leased 30,000 tons of $\mathrm{CO}_{2}$ offset credits from the PNDSA. This effort involved fifteen farmers from Idaho, set an example, and provided educational opportunities for other landowners, organizations, and agencies to prepare for future trades.

Two other important milestones accomplished by the Advisory Committee were:

- The signing of a Memorandum of Understanding with the Big Sky Regional Carbon Sequestration Partnership (BSP) on January 10, 2005

- The development of the Idaho Carbon Exchange Framework document completed on August 15, 2007. 
At the November 15, 2007 Carbon Sequestration Advisory Committee meeting, the decision was made to use components of the Framework document to help focus on five key components for implementation, and move forward on action items related to those key components listed as follows:

- Information Outreach

- Carbon Sequestration Pilot Projects

- Technical Research

- Geologic Sequestration

- Carbon Encumbrance Registry for the state of Idaho.

\subsection{Current Status}

Current status of the Carbon Sequestration Advisory Committee's progress in implementing the five key focus components:

\section{Information Outreach}

- Advisory Committee is currently implementing its information and outreach plan.

- The ISCC has added "how-to" information to its website www.scc.idaho.gov for carbon sequestration, and assisted with adding information to the Idaho OnePlan website www.oneplan.org to provide information directly to farmers and ranchers who want to initiate carbon trading activities.

- On January 26, 2006 the Advisory Committee meeting was held in Idaho Falls, and included participation of local farmers and ranchers in order to assess their interest in participating in a pilot carbon sequestration project. Interest levels were high. Three additional follow-up meetings were held in the area with local landowners and operators, local Soil Conservation Districts, the High Country and Three Rivers RC\&D Council representatives, and the National Carbon Offset Coalition (NCOC).

- Numerous presentations have been offered to agencies, interest groups, farmers and ranchers, and legislative committees.

- A member of the Advisory Committee (Dick Wittman) represented Idaho agricultural interests during national congressional hearings for potential cap-and-trade legislation.

- On November 5, 2008 in Orofino, Idaho there was a Regional Agricultural and Forestry Workshop entitled, "Carbon Sequestration: Understanding It, Owning It, Trading It."

- Informational brochures printed and distributed by ISCC to all Soil Conservation Districts.

2. Carbon Trading Pilot Projects in Idaho

- PNDSA pioneered the first agricultural carbon credit leasing project in 2002 in Washington and Idaho, and provided an example for others to see the potential benefits of carbon trading. Today a number of Idaho farmers that are members of PNDSA are participating in cropland trades involving no-till (direct seed) and precision agriculture. These trades are aggregated by PNDSA and marketed to private entities.

- The Nez Perce Tribe is currently implementing Idaho's first forestry trade, aggregated through the NCOC, and marketed on the CCX.

- The High Country Resource Conservation and Development (RC\&D) Council, Three Rivers RC\&D Council, and the Bear River RC\&D Council, along with several local Soil Conservation Districts in Eastern Idaho, are currently involved with the ISCC in working with a number of ranchers to develop and implement a rangeland pilot project aggregated by NCOC and marketed through the CCX. 
- The Clearwater RC\&D Council is working on an urban forestry carbon trading project with the city of Moscow, which would also be aggregated by NCOC and marketed through the CCX.

3. Research

- ISCC is working with soil scientists and agronomists from the University of Idaho, Washington State University, and the Agricultural Research Service (ARS) to research and quantify soil organic carbon values under different management practices for dryland agriculture in Idaho. It is our intention to forward this data to CCX in support of our request for a "Cropping Region Designation" in Idaho.

- ISCC worked with the Natural Resources Conservation Service (NRCS) to develop GIS maps and tables showing organic matter concentrations for all soils mapped within the state. This statewide characterization can be broken out and displayed by county, watershed, and/or individual parcels.

- ISCC is also working with NRCS to refine the COMET model for the state of Idaho, which is a model that estimates carbon content in the soil under various tillage systems. The purpose is to obtain a better tool to calculate carbon estimates for sequestration projects.

4. Geologic Sequestration

(See previous discussion.)

\section{Carbon Sequestration Registry}

ISCC is currently working in a template for a Carbon Encumbrance Registry to record and track all carbon sequestered within the state, including all trades with private entities and those traded on the CCX or other exchanges.

\subsection{Opportunities, Challenges, Needs}

The opportunities for Idaho agriculture to sequester carbon and reduce other greenhouse gases are tremendous.
Idaho has the potential to sequester and/or offset nearly 15 million metric tons of carbon dioxide equivalents $\left(\mathrm{CO}_{2} \mathrm{e}\right)$ per year. Afforestation, biofuels production, biogas recovery, no-till, nutrient management, methane reductions, and agricultural energy reductions could provide most of the State's sequestration and emission offsets ",

Currently, there are 5,450,000 acres of cropland in Idaho, of which 784,000 are enrolled in the Conservation Reserve Program, and 5,420,000 acres of private rangeland. In addition, there are approximately 700 dairy operations in Idaho. ${ }^{\mathrm{g}}$ Most are located in the Magic Valley, and are concentrated within a five-county area. (See the Biogas Task Force document for details related to dairy issues and the potential for anaerobic digesters: http://www.energy.idaho.gov/energyalliance/d/biogas_resources_report.pdf)

Thanks to the work of the Idaho Carbon Sequestration Advisory Committee, ISCC field staff, and the Idaho Association of Soil Conservation Districts, Idaho's agricultural community has an increased awareness and interest in climate issues and carbon sequestration potential for:

- Reducing agricultural input into the problem

- Creating an additional income stream

f. Carbon Sequestration on Idaho Agriculture and Forest Lands, p.p. 2, 3, February 2003.

g. 2003 NRI Data from the Natural Resources Conservation Service. 
- Escalating the ancillary benefits of increased soil productivity, including:

- reduced erosion

- installation and maintenance of conservation practices

- improved water quality

- fuel and emissions reduction.

Some of the agricultural conservation practices and related activities that can increase carbon sequestration and reduce related GHG emissions are:

- Residue management (direct seed, no-till)

- Nutrient management (fertilizer and manure application)

- Riparian buffers

- Windbreaks

- Permanent vegetation

- Prescribed grazing

- $\quad$ Range and pasture planting

- Methane reduction from livestock and waste storage ponds

- Biogas recovery - anaerobic digesters.

The Carbon Sequestration Advisory Committee has worked to establish communication links and provide information to facilitate successful carbon sequestration and marketing of carbon credits for agricultural producers.

In terms of challenges, the main concern is that we are largely dependent upon national political and regulatory decisions that have yet to be made.

- Will we have a national cap-and-trade program?

- What will the ramifications be on the current voluntary market?

- Will agriculture be considered as part of the solution?

Right now there are a lot of questions that will hopefully be answered over the next year or two.

The second challenge involves the economic potential to adopt practices and strategies that sequester carbon within the agricultural sector. Economic potential is limited, and will fluctuate depending on the market price of carbon credits or the availability of state and federal programs that offer financial incentives to agricultural producers within Idaho to sequester additional carbon. We need to identify the relative economic viability of each potential practice and resource management system; including those involving animal waste management and anaerobic digesters for Idaho's expanding dairy industry. Along with this challenge is the need for Idaho to evaluate the overall competitiveness of the agricultural sector's ability to reduce net emissions of GHG in comparison to other emission reduction opportunities available within the state. At present, there is no information available on the relative economic viability of the practices, systems, and technologies available. This information could be helpful to the state, other involved agencies, and individual producers in prioritizing future investment dollars and financial incentives.

The third major challenge is the fragmentation of state agencies involved with reducing GHG emissions and carbon sequestration. The Carbon Sequestration Advisory Committee has made significant progress in working with agencies involved with agriculture and forestry. However, there is still an overarching lack of understanding and commitment to becoming engaged in the solution processes for 
GHG reduction and carbon sequestration. Each of the agencies is tasked with addressing and focusing resources and staff on traditional mandates and programs. Without direction and support from the Legislature, agency leaders are hesitant to redirect staff and funding toward solving GHG and carbon sequestration issues. As an example, the ISCC currently works on carbon sequestration under an unfunded mandate as per Idaho Code 22-5103. During a period of tight budgets, limited staff, and expanding workloads, the task of taking on an additional program can be daunting.

\subsection{Conclusions}

- The overall potential to sequester carbon and reduce related GHG emission from Idaho agriculture is great.

- Agricultural producers have shown a high level of interest in participating in pilot projects, and are willing to implement best management practices that provide multiple environmental and economic benefits, including carbon sequestration practices.

- Forward momentum in the carbon trading arena has slowed as a result of the current economic climate and political unknowns related to potential national cap-and-trade legislation or regulation.

- A large informational and educational gap exists between savvy buyers, aggregators, and others involved with carbon trading markets and the potential sellers (agricultural producers and their supporting organizations and agencies).

- Idaho is well behind other states in indentifying opportunities, and could be less economically competitive as a result.

- A lack of interagency coordination exists between agencies involved with carbon sequestration and GHG issues, in both the state and federal levels.

\subsection{Recommendations}

- The Idaho Carbon Sequestration Advisory Committee will proactively track potential national cap-andtrade legislation or other regulatory legislation and policies that may impact carbon trading opportunities or future markets (See Appendix A).

- The Idaho Carbon Sequestration Advisory Committee should support and work with ISCC, technical agencies, universities, and the BSS Partnership to develop criteria for measuring baseline standards, field evaluation tools, and protocols for field validation, and develop and/or enhance carbon sequestration models.

- The Idaho Soil Conservation Commission and Idaho's 51 Conservation Districts should continue and accelerate their information and education efforts. Special emphasis should be placed on updating and informing the legislature.

- The Idaho Soil Conservation Commission and Idaho's 51 Conservation Districts should continue pursuing agricultural pilot projects within the voluntary carbon trading market and prepare for integration with future national offset processes, regulations, and/or guidelines.

- The Idaho Carbon Sequestration Advisory Committee should continue pursuing a "Designated Cropping Region" for Idaho from the Chicago Climate Exchange. They should also pursue potential participation with the Green Exchange, New York Mercantile Exchange, and possible trading opportunities directly with private entities.

- The Idaho Carbon Sequestration Advisory Committee and the Idaho Soil Conservation Commission should continue working with PNDSA, U of I, and WSU in developing carbon sequestration field data on cropland, field-expedient carbon flux measuring tools, and protocols to strengthen this validation process. 
- The Idaho Carbon Sequestration Advisory Committee should pursue funding for:

- Evaluating the relative economic competitiveness of possible technologies to reduce emissions and increase sequestration of carbon

- Strengthening Idaho's position within a future carbon market relative to that of other states (see Appendix A)

- Identifying which sectors within Idaho could be most affected by possible future GHG legislation.

- The Idaho Carbon Sequestration Advisory Committee should better define roles and responsibilities of involved state and federal agencies, and strengthen communication links between agencies. Common goals and objectives needs to be established through MOUs and/or working agreements. The potential for integrating and targeting funding programs and technical resources needs to be evaluated.

- The Idaho Carbon Sequestration Advisory Committee should strengthen coordination with the Idaho Association of Soil Conservation Districts and the National Association of Conservation Districts.

- The Idaho Carbon Sequestration Advisory Committee should work with ISCC and other state agencies to develop a Carbon Encumbrance Registry.

\subsubsection{Pros and cons}

Table 6. Agriculture carbon recommendations pros and cons.

\begin{tabular}{|c|c|c|}
\hline Options & Pros & Cons \\
\hline $\begin{array}{l}\text { The Idaho Carbon } \\
\text { Sequestration Advisory } \\
\text { Committee will proactively } \\
\text { track potential national cap- } \\
\text { and-trade legislation or other } \\
\text { regulatory legislation and } \\
\text { policies that may impact } \\
\text { carbon trading opportunities or } \\
\text { future markets }\end{array}$ & $\begin{array}{l}\text { This effort would forewarn } \\
\text { Idaho's regulators and policy } \\
\text { makers of major changes that } \\
\text { would impact the state }\end{array}$ & $\begin{array}{l}\text { The Committee, has not been } \\
\text { very active in the last few } \\
\text { years and its members } \\
\text { participate on a voluntary } \\
\text { basis, therefore any increase } \\
\text { in activity or responsibility } \\
\text { would require a } \\
\text { commensurate expenditure of } \\
\text { resources }\end{array}$ \\
\hline $\begin{array}{l}\text { The Idaho Carbon } \\
\text { Sequestration Advisory } \\
\text { Committee should support and } \\
\text { work with ISCC, technical } \\
\text { agencies, universities, and the } \\
\text { BSS Partnership to develop } \\
\text { criteria for measuring baseline } \\
\text { standards, field evaluation } \\
\text { tools, and protocols for field } \\
\text { validation, and develop and/or } \\
\text { enhance carbon sequestration } \\
\text { models }\end{array}$ & $\begin{array}{l}\text { These tools would be helpful } \\
\text { in planning and deploying the } \\
\text { recommended CCS activities } \\
\text { contained in this report }\end{array}$ & $\begin{array}{l}\text { It is not clear how the ICSAC } \\
\text { would take on such activities, } \\
\text { without having the ability to } \\
\text { allocate funds to the } \\
\text { participants }\end{array}$ \\
\hline
\end{tabular}


Table 6. (continued).

\begin{tabular}{|c|c|c|}
\hline Options & Pros & Cons \\
\hline $\begin{array}{l}\text { The Idaho Soil Conservation } \\
\text { Commission and Idaho's } 51 \\
\text { Conservation Districts should } \\
\text { continue and accelerate their } \\
\text { information and education } \\
\text { efforts. Special emphasis } \\
\text { should be placed on updating } \\
\text { and informing the legislature }\end{array}$ & $\begin{array}{l}\text { Integrating the ISCC and the } \\
\text { 51 CD for this purposes of } \\
\text { carbon mitigation/ } \\
\text { sequestration would provide } \\
\text { the baseline information to the } \\
\text { state legislators and land } \\
\text { managers regarding how to } \\
\text { implement agricultural based } \\
\text { carbon Storage. } \\
\text { Additionally, this } \\
\text { recommendation would } \\
\text { provide an approximation of } \\
\text { the credits available for carbon } \\
\text { storage in the state, and the } \\
\text { location of that opportunity }\end{array}$ & $\begin{array}{l}\text { The distribution of resources } \\
\text { may not be equable and } \\
\text { therefore some of the districts } \\
\text { would benefit more from this } \\
\text { kind of effort than other } \\
\text { would. }\end{array}$ \\
\hline $\begin{array}{l}\text { The Idaho Soil Conservation } \\
\text { Commission and Idaho's } 51 \\
\text { Conservation Districts should } \\
\text { continue pursuing agricultural } \\
\text { pilot projects within the } \\
\text { voluntary carbon trading } \\
\text { market and prepare for } \\
\text { integration with future } \\
\text { national offset processes, } \\
\text { regulations, and/or guideline }\end{array}$ & $\begin{array}{l}\text { Would provide additional } \\
\text { revenue to Idaho's agriculture } \\
\text { community } \\
\text { An additional benefit maybe } \\
\text { that water quality and soil } \\
\text { erosion would be reduced }\end{array}$ & $\begin{array}{l}\text { Early adoption of agriculture } \\
\text { based carbon credits may hurt } \\
\text { the landowner, as the current } \\
\text { price for carbon credits is } \\
\text { very low. Waiting to enroll } \\
\text { when if and when a carbon } \\
\text { reduction policy is in place } \\
\text { and the prices are higher } \\
\text { would be more financially } \\
\text { profitable for the landowner. }\end{array}$ \\
\hline $\begin{array}{l}\text { The Idaho Carbon } \\
\text { Sequestration Advisory } \\
\text { Committee and the Idaho Soil } \\
\text { Conservation Commission } \\
\text { should continue working with } \\
\text { PNDSA, U of I, and WSU in } \\
\text { developing carbon } \\
\text { sequestration field data on } \\
\text { cropland, field-expedient } \\
\text { carbon flux measuring tools, } \\
\text { and protocols to strengthen } \\
\text { this validation process. }\end{array}$ & $\begin{array}{l}\text { Agriculture capture of carbon } \\
\text { is still the "low hanging fruit" } \\
\text { with low adoption cost and } \\
\text { relatively high direct and } \\
\text { ancillary payback, the } \\
\text { characterization of field data } \\
\text { relative to Idaho's agriculture } \\
\text { carbon storage potential would } \\
\text { facilitate landowner adoption } \\
\text { options }\end{array}$ & $\begin{array}{l}\text { The risk here is that the } \\
\text { Federal Government, may } \\
\text { never pass a national carbon } \\
\text { emission standard, if this is } \\
\text { the case, the money spent to } \\
\text { do the "carbon" potion of this } \\
\text { work in large part have been } \\
\text { wasted }\end{array}$ \\
\hline
\end{tabular}


Table 6. (continued).

\begin{tabular}{|c|c|c|}
\hline Options & Pros & Cons \\
\hline $\begin{array}{l}\text { The Idaho Carbon } \\
\text { Sequestration Advisory } \\
\text { Committee and the Carbon } \\
\text { Issues Task Force should } \\
\text { better define roles and } \\
\text { responsibilities of involved } \\
\text { state and federal agencies, and } \\
\text { strengthen communication } \\
\text { links between agencies. } \\
\text { Common goals and objectives } \\
\text { needs to be established } \\
\text { through MOUs and/or } \\
\text { working agreements. The } \\
\text { potential for integrating and } \\
\text { targeting funding programs } \\
\text { and technical resources needs } \\
\text { to be evaluated. }\end{array}$ & $\begin{array}{l}\text { A better definition of the } \\
\text { responsibilities of these two } \\
\text { groups would be beneficial to } \\
\text { their ultimate success. } \\
\text { Furthermore, as the roles and } \\
\text { responsibilities of these two } \\
\text { groups seem to overlap, this } \\
\text { clarification would help define } \\
\text { those areas, and make these } \\
\text { two groups more autonomous. }\end{array}$ & $\begin{array}{l}\text { While identifying common } \\
\text { goals is important, the } \\
\text { establishment of MOU's and } \\
\text { working agreements has some } \\
\text { risk. MOU's do not always } \\
\text { facilitate the desired } \\
\text { outcomes and often lead to } \\
\text { more confusion regarding } \\
\text { what responsibilities each } \\
\text { entity has relative to funding, } \\
\text { or the lack thereof. }\end{array}$ \\
\hline $\begin{array}{l}\text { The Idaho Carbon } \\
\text { Sequestration Advisory } \\
\text { Committee should pursue } \\
\text { funding for: } \\
\text { Evaluating the relative } \\
\text { economic competitiveness of } \\
\text { possible technologies to } \\
\text { reduce emissions and increase } \\
\text { sequestration of carbon } \\
\text { Strengthening Idaho's position } \\
\text { within a future carbon market } \\
\text { relative to that of other states } \\
\text { (see Appendix A) }\end{array}$ & & $\begin{array}{l}\text { Because this organization is a } \\
\text { volunteer group, it is unclear } \\
\text { who would receive the } \\
\text { funding and who would do } \\
\text { the work. There currently is } \\
\text { not a mechanism in place for } \\
\text { the ICSAC to accept or solicit } \\
\text { funds to do said work. } \\
\text { This organization is not } \\
\text { configured to act on behalf of } \\
\text { the state or its organization, } \\
\text { and there is not currently any } \\
\text { pending legislation for which } \\
\text { the organization can plan } \\
\text { against. }\end{array}$ \\
\hline $\begin{array}{l}\text { The Idaho Carbon } \\
\text { Sequestration Advisory } \\
\text { Committee should strengthen } \\
\text { coordination with the Idaho } \\
\text { Association of Soil } \\
\text { Conservation Districts and the } \\
\text { National Association of } \\
\text { Conservation Districts }\end{array}$ & $\begin{array}{l}\text { Communication between the } \\
\text { ISCAC and the IASC and the } \\
\text { NACD would strengthen each } \\
\text { groups understanding of the } \\
\text { others needs and strengths. } \\
\text { Because of the charter } \\
\text { responsibilities of the ICSAC } \\
\text { and the IASC, it is a natural fit } \\
\text { for the two organizations to } \\
\text { communicate on a more } \\
\text { regular basis, especially given } \\
\text { that two of the founding } \\
\text { members of the ICSAC are no } \\
\text { longer engaged in either group }\end{array}$ & $\begin{array}{l}\text { Most of the participants or } \\
\text { employees of these } \\
\text { organizations time is already } \\
\text { heavily leveraged doing their } \\
\text { required tasks, the addition } \\
\text { constraints on existing } \\
\text { personnel would be unwise. } \\
\text { Even if there were personnel } \\
\text { with the time to spend in this } \\
\text { communication effort, it is } \\
\text { unlikely given budgetary } \\
\text { constraints that financial } \\
\text { resources could be brought to } \\
\text { this type of activity }\end{array}$ \\
\hline
\end{tabular}




\section{SUMMARY OF RECOMMENDATIONS \\ 5.1 Emissions Reduction/Offset Credits}

- Continue to participate as an observer to the WCI

- Encourage Idaho companies to join TCR

- Create a closer link between the IDEQ and the OER as it relates to climate change

- Improve upon the state's current GHG Emissions Inventory

- Look at what other states have done or are doing (for example, Montana)

- Unite sectors that might have potential offsets (i.e., forestry, agriculture, waste management, etc.).

\subsection{Geologic Sequestration}

- Develop of regulatory framework for geologic CCS

- Integrated involvement of effected stakeholder in public outreach setting

- Coordination between air, water, and land use objectives

- Collaboration with neighboring states and federal agencies

- Engage public in education and outreach regarding CCS

- Characterize statewide geologic storage potential

- Charge the Idaho Geological Survey to lead other state entities in coordinated characterizations effort

- Leverage similar regional federal projects

- Develop technologies required for unconventional CCS

- Engage industry representatives to define key technical issues limiting unconventional CCS

- Coordinate relevant research activities of state universities and INL through the CAES.

\subsection{Forestry}

- Resolve whether Idaho's forests are a net source of emissions or a net sink for atmospheric carbon.

- Develop GHG inventory protocol to include wilderness areas and measure changes in wildfire extent and dead wood.

- Support carbon credits for a full range of forestry offset opportunities, including bioenergy.

- Develop quantitative models of forest carbon response and identify carbon best management practices.

- Increase USFS budget for restoration and hazardous fuel reduction.

- Provide outreach efforts to develop support for active forest management.

\subsection{Agriculture}

- The Idaho Carbon Sequestration Advisory Committee will proactively track potential national cap-andtrade legislation or other national and state regulatory legislation and policies that may impact carbon trading opportunities or future markets available to Idaho (see Appendix A).

- The Idaho Soil Conservation Commission and Idaho's 51 Conservation Districts should continue and accelerate their information and education efforts. Special emphasis should be placed on updating and informing the legislature. 
- The Idaho Soil Conservation Commission and Idaho's 51 Conservation Districts should continue pursuing agricultural pilot projects within the voluntary carbon trading market.

- The Idaho Carbon Sequestration Advisory Committee should continue pursuing a "Designated Cropping Region" for Idaho from the Chicago Climate Exchange. They should also pursue potential participation with the Green Exchange, New York Mercantile Exchange, and possible trading opportunities directly with private entities.

- The Idaho Carbon Sequestration Advisory Committee and the Idaho Soil Conservation Commission should continue working with PNDSA, U of I, and WSU in developing carbon sequestration field data on cropland.

- The Idaho Carbon Sequestration Advisory Committee should pursue funding for:

- Developing and implementing technologies for reducing GHG from the dairy and livestock sector

- Evaluating the relative economic competitiveness of possible technologies to reduce emissions and increase sequestration of carbon

- Strengthening Idaho's position within a future carbon market relative to that of other states

- Identifying which sectors within Idaho could be most affected by possible future GHG legislation.

- The Idaho Carbon Sequestration Advisory Committee should better define roles and responsibilities of involved state agencies, and strengthen communication links between agencies. Common goals and objectives needs to be established through MOUs and/or working agreements. The potential for integrating and targeting funding programs needs to be evaluated.

- The Idaho Carbon Sequestration Advisory Committee should strengthen coordination with the Idaho Association of Soil Conservation Districts and the National Association of Conservation Districts.

- The Idaho Carbon Sequestration Advisory Committee should pursue the development of a carbon encumbrance registry. 


\section{Appendix A}

\section{State CCS Legislative and Regulatory Developments}




\section{Prepared and Maintained by Alston \& Bird LLP Last Updated 4/27/09 Active/High-Priority Legislation}

\begin{tabular}{|c|c|c|c|}
\hline State & Legislation & Status & Link to Bill Text/News \\
\hline Indiana & $\begin{array}{l}\text { Introduced on January } 13,2009 \text {, } \\
\text { HB } 1412 \text { provides incentives for } \\
\text { "clean coal and energy } \\
\text { projects", including project } \\
\text { using coal from the Illinois } \\
\text { Basin and projects that involve } \\
\text { CCS. Incentives include cost } \\
\text { recovery, enhanced returns on } \\
\text { shareholder equity, and product } \\
\text { offtake incentives. }\end{array}$ & $\begin{array}{l}\text { Mar } 24^{\text {th }}-\text { pending } \\
\text { before the Committee } \\
\text { on Commerce, Energy, } \\
\text { Technology and } \\
\text { Utilities. }\end{array}$ & $\begin{array}{l}\frac{\text { http://www.in.gov/legislat }}{\text { ive/bills/2009/PDF/IN/IN }} \\
\underline{\text { 1412.1.pdf }}\end{array}$ \\
\hline Kansas & $\begin{array}{l}\text { Introduced on January 20, } 2009 \text {, } \\
\text { HB } 2038 \text { establishes capture } \\
\text { requirements for different } \\
\text { classes of power generating } \\
\text { facilities and directs the } \\
\text { Department of Health \& } \\
\text { Environment to propose } \mathrm{CO}_{2} \\
\text { emission limits for "carbon } \\
\text { emitters for which [CCS] } \\
\text { technologies are available and } \\
\text { cost-effective." }\end{array}$ & $\begin{array}{l}\text { January } 21^{\text {st }}-\text { referred } \\
\text { to Energy } \& \text { Utilities } \\
\text { January } 26^{\text {th }}-\text { hearing }\end{array}$ & $\frac{\text { http://www.kslegislature.o }}{\text { rg/bills/2010/2038.pdf }}$ \\
\hline Kentucky & $\begin{array}{l}\text { Introduced on February 5,2009, } \\
\text { HB } 285 \text { authorizes the Kentucky } \\
\text { Economic Development } \\
\text { Authority to award incentives to } \\
\text { one pilot project that involves } \\
\text { the construction of a new IGCC } \\
\text { electric generation plant; the } \\
\text { construction of a new } \\
\text { ultrasupercritical, oxyfuel, or } \\
\text { other electric generation plant; } \\
\text { or the retrofit of an existing } \\
\text { coal-fired power plant. The } \\
\text { project must include or allow } \\
\text { CCS. Additional limits apply. }\end{array}$ & $\begin{array}{l}\text { Feb } 6^{\text {th }}-\text { to } \\
\text { Appropriations } \& \\
\text { Revenue } \\
\text { Feb } 13^{\text {th }}-\text { posted in } \\
\text { committee } \\
\text { Feb } 23^{\text {rd }}-\text { reported } \\
\text { favorably with } \\
\text { substitute } \\
\text { Feb } 24^{\text {th }}-\text { to Rules } \\
\text { Feb } 25^{\text {th }}-\text { posted for } \\
\text { passage in the regular } \\
\text { orders of the day for } \\
\text { Feb. } 26^{\text {th }} \\
\text { Mar } 11^{\text {th }}-\text { returned to } \\
\text { Rules. }\end{array}$ & $\begin{array}{l}\text { http://www.lrc.ky.gov/rec } \\
\text { ord/09RS/HB285/bill.doc }\end{array}$ \\
\hline
\end{tabular}




\begin{tabular}{|c|c|c|c|}
\hline State & Legislation & Status & Link to Bill Text/News \\
\hline Kentucky & $\begin{array}{l}\text { Introduced on February 9, } 2009 \text {, } \\
\text { HB } 351 \text { establishes as state } \\
\text { policy the involvement of the } \\
\text { Kentucky Geological Survey } \\
\text { and Center for Applied Energy } \\
\text { Research at the University of } \\
\text { Kentucky in CCS demonstration } \\
\text { projects; to further such } \\
\text { projects, the state of Kentucky } \\
\text { agrees to "accept and receive [] } \\
\text { all rights, tight, and interests in } \\
\text { the sequestered gas, including } \\
\text { any current or future } \\
\text { environmental benefits, } \\
\text { marketing claims, tradable } \\
\text { credits, emission allocations, or } \\
\text { offsets (voluntary or } \\
\text { compliance-based) ...." }\end{array}$ & $\begin{array}{l}\text { Feb } 10^{\text {th }}-\text { to Natural } \\
\text { Resources } \& \\
\text { Environment } \\
\text { Feb } 23^{\text {rd }}-\text { posted in } \\
\text { committee }\end{array}$ & $\begin{array}{l}\text { http://www.lrc.ky.gov/rec } \\
\text { ord/09RS/HB351/bill.doc }\end{array}$ \\
\hline Kentucky & $\begin{array}{l}\text { Introduced on February 11, } \\
2009, \text { House Joint Resolution } \\
126 \text { expresses the Legislature's } \\
\text { support for the Kentucky } \\
\text { Geological Survey's pursuit of } \\
\text { federal funding opportunities for } \\
\text { CCS under the American } \\
\text { Recovery \& Reinvestment Act } \\
\text { of } 2009 \text {. }\end{array}$ & $\begin{array}{l}\text { Feb } 12^{\text {th }}-\text { to Natural } \\
\text { Resources } \& \\
\text { Environment } \\
\text { Feb } 23^{\text {rd }}-\text { posted in } \\
\text { committee } \\
\text { Feb } 26^{\text {th }}-\text { reported } \\
\text { favorably, } 1 \text { st reading, } \\
\text { to Consent Calendar } \\
\text { Feb } 27^{\text {th }}-2 \text { nd reading, } \\
\text { to Rules; posted for } \\
\text { passage in the Consent } \\
\text { Orders of the Day for } \\
\text { Tuesday, March } 3,2009 \\
\text { Mar } 3^{\text {rd }}-3 \text { rd reading, } \\
\text { adopted } 100-0 \\
\text { Mar } 4^{\text {th }}-\text { received in } \\
\text { Senate } \\
\text { Mar } 6^{\text {th }}-\text { to Natural } \\
\text { Resources and Energy } \\
\text { Mar } 9^{\text {th }}-\text { taken from } \\
\text { committee; } 1 \text { st reading; } \\
\text { returned to Natural } \\
\text { Resources and Energy; } \\
\text { reported favorably, to } \\
\text { Calendar as a Consent } \\
\text { Bill } \\
\text { Mar } 10^{\text {th }}-2 \text { nd reading, } \\
\text { to Rules. }\end{array}$ & $\begin{array}{l}\text { http://www.lrc.ky.gov/rec } \\
\text { ord/09RS/HJ126/bill.doc }\end{array}$ \\
\hline
\end{tabular}




\begin{tabular}{|c|c|c|c|}
\hline State & Legislation & Status & Link to Bill Text/News \\
\hline Kentucky & $\begin{array}{l}\text { Introduced on February } 23, \\
2009, \text { HB } 537 \text { authorizes the } \\
\text { creation of a carbon } \\
\text { management legal issues study } \\
\text { group to investigate and report } \\
\text { on CCS policy } \\
\text { recommendations by October } \\
31,2009 \text {. }\end{array}$ & $\begin{array}{l}\text { Feb } 24^{\text {th }}-\text { to Tourism } \\
\text { Development } \& \text { Energy } \\
\text { Feb } 26^{\text {th }}-\text { reported } \\
\text { favorably } \\
\text { Feb } 27^{\text {th }}-\text { to Rules } \\
\text { Mar } 2^{\text {nd }}-\text { passed House } \\
\text { as amended } \\
\text { Mar } 5^{\text {th }}-\text { to Natural } \\
\text { Resources \& Energy } \\
\text { Mar } 9^{\text {th }}-\text { reported } \\
\text { favorably } \\
\text { Mar } 10^{\text {th }}-\text { to Rules } \\
\text { Mar } 13^{\text {th }}-\text { passed } \\
\text { Senate as amended } \\
\text { Mar } 13^{\text {th }}-\text { returned to } \\
\text { House }\end{array}$ & $\begin{array}{l}\text { http://www.lrc.ky.gov/rec } \\
\text { ord/09RS/HB537/bill.doc }\end{array}$ \\
\hline Louisiana & $\begin{array}{l}\text { House Bill } 661 \text { was introduced } \\
\text { on April 16, } 2009 \text {. The } \\
\text { "Louisiana Geologic } \\
\text { Sequestration of Carbon } \\
\text { Dioxide Act," provides } \\
\text { definitions of key terms relating } \\
\text { to sequestration. It gives the } \\
\text { commissioner of conservation } \\
\text { the authority to regulate } \mathrm{CO}_{2} \\
\text { storage. States that after } 10 \\
\text { years of completion of injection, } \\
\text { the state will assume all liability, } \\
\text { unless the Carbon Dioxide } \\
\text { Geologic Trust Fund has been } \\
\text { depleted. }\end{array}$ & Apr $16^{\text {th }}$-Introduced. & $\begin{array}{l}\text { http://www.legis.state.la.u } \\
\text { s/billdata/streamdocument } \\
\underline{\text { asp?did=645317 }}\end{array}$ \\
\hline Michigan & $\begin{array}{l}\text { Introduced on January } 22,2009, \\
\text { HB } 4016 \text { provides a tax credit } \\
\text { equal to the cost of "purchasing, } \\
\text { leasing, or constructing carbon } \\
\text { dioxide capture machinery, } \\
\text { equipment, or pipeline } \\
\text { infrastructure and the cost of } \\
\text { materials used in preparing, } \\
\text { maintaining, or capping a } \\
\text { carbon dioxide injection well". }\end{array}$ & $\begin{array}{l}\text { Jan } 22^{\text {nd }}-\text { referred to } \\
\text { Committee on Energy } \& \\
\text { Technology } \\
\text { Jan } 27^{\text {th }}-\text { printed bill } \\
\text { filed }\end{array}$ & $\begin{array}{l}\text { http://www.legislature.mi. } \\
\text { gov/documents/2009- } \\
\text { 2010/billintroduced/Hous } \\
\text { e/pdf/2009-HIB-4016.pdf }\end{array}$ \\
\hline
\end{tabular}




\begin{tabular}{|c|c|c|c|}
\hline State & Legislation & Status & Link to Bill Text/News \\
\hline Mississippi & $\begin{array}{l}\text { Introduced on January } 19,2009 \text {, } \\
\text { HB } 1459 \text { levies a gross income } \\
\text { tax of } 1.5 \% \text { on businesses } \\
\text { engaged in the "sale of naturally } \\
\text { occurring carbon dioxide and } \\
\text { anthropogenic carbon dioxide } \\
\text { lawfully injected into the earth } \\
\text { for: } 1 . \text { Use is an enhanced oil } \\
\text { recovery project, including, but } \\
\text { not limited to, use for cycling, } \\
\text { repressuring or lifting of oil; or } \\
2 . \text { Permanent sequestration in a } \\
\text { geological formation." }\end{array}$ & $\begin{array}{l}\text { Mar } 23^{\text {rd }}-\text { Passed the } \\
\text { Mississippi Legislature } \\
\text { and sent to the Governor } \\
\text { for signature } \\
\text { Mar } 31^{\text {st }} \text {-Signed by } \\
\text { Governor. }\end{array}$ & $\begin{array}{l}\text { http://billstatus.ls.state.ms. } \\
\text { us/documents/2009/pdf/H } \\
\text { B/1400- } \\
\text { 1499/HB1459IN.pdf }\end{array}$ \\
\hline Montana & $\begin{array}{l}\text { Not yet introduced, draft bill } \\
\text { LC0194 would require the } \\
\text { Board of Environmental Review } \\
\text { to set standards for the capture, } \\
\text { transportation and storage of } \\
\mathrm{CO}_{2} \text { at coal-fired electrical } \\
\text { generation and synthetic fuels } \\
\text { facilities. The bill would require } \\
100 \% \text { capture and subsequent } \\
\text { "permanent storage", although } \\
\text { offsets could be used in a } \\
\text { limited fashion. }\end{array}$ & $\begin{array}{l}\text { Dec 24, } 2008 \text { - draft } \\
\text { legislation available } \\
\text { This effort appears to be } \\
\text { have stalled and been } \\
\text { overtaken by events (see } \\
\text { SB } 66 \text { and HB } 502 \\
\text { below) }\end{array}$ & $\underline{\text { http://data.opi.mt.gov/bills }}$ \\
\hline Montana & $\begin{array}{l}\text { Introduced on December } 10 \text {, } \\
2008, \mathrm{SB} 66 \text { authorizes the } \\
\text { Board of Environmental Review } \\
\text { to issue CCS regulations that } \\
\text { broadly follow whatever federal } \\
\text { requirements may emerge; } \\
\text { specific features of note include: } \\
\text { (i) requirement for operator to } \\
\text { obtain and hold insurance for } \\
75 \text { years following well closure; } \\
\text { (ii) establishment of pore space } \\
\text { rights as attribute of surface } \\
\text { estate; and (iii) disqualification } \\
\text { of CO }{ }_{2} \text {-EOR from being able to } \\
\text { do storage under Class II. CO }{ }_{2-} \\
\text { EOR operations can convert to } \\
\text { storage, and thus become } \\
\text { subject to the storage rules, but } \\
\text { cannot do storage and engage in } \\
\text { oil production concurrently } \\
\text { while remaining subject to } \\
\text { regulation by the Board of Oil \& } \\
\text { Gas Conservation. }\end{array}$ & $\begin{array}{l}\text { Dec } 16,2008 \text { - referred } \\
\text { to Energy \& } \\
\text { Telecommunications } \\
\text { Jan } 5,2009 \text { - first } \\
\text { reading } \\
\text { Jan } 15^{\text {th }}-\text { hearing } \\
\text { Jan } 23^{\text {rd }}-- \text { tabled }\end{array}$ & $\frac{\text { http://data.opi.mt.gov/bills }}{\text { /2009/billpdf/SB0066.pdf }}$ \\
\hline
\end{tabular}




\begin{tabular}{|c|c|c|c|}
\hline State & Legislation & Status & Link to Bill Text/News \\
\hline Montana & $\begin{array}{l}\text { Introduced on February 9, } 2009 \text {, } \\
\text { HB } 502 \text { authorizes the Board of } \\
\text { Environmental Review to issue } \\
\text { CCS regulations. HB } 502 \text { is } \\
\text { broadly similar to SB } 66 \\
\text { (discussed above) except for the } \\
\text { following: (i) pore space is } \\
\text { vested in the state of Montana; } \\
\text { and (ii) contamination of ground } \\
\text { water in a regulated geologic } \\
\text { sequestration site is excluded } \\
\text { from the definition of } \\
\text { "pollution." }\end{array}$ & $\begin{array}{l}\text { Feb } 9^{\text {th }}-- \text { referred to } \\
\text { Natural Resources } \\
\text { Committee } \\
\text { Feb } 18^{\text {th }}-\text { hearing } \\
\text { Mar } 20^{\text {th }}-\text { tabled }\end{array}$ & http://data.opi.mt.gov/bills \\
\hline Montana & $\begin{array}{l}\text { Introduced on February 20, } \\
\text { 2009, SB } 498 \text { authorizes the } \\
\text { Board of Oil \& Gas to issue } \\
\text { CCS regulations. The legislation } \\
\text { differs from SB } 66 \text { and HB 502, } \\
\text { in the following respects: (i) oil } \\
\text { \& gas, not environmental, } \\
\text { regulators are in charge of the } \\
\text { CCS regulators (although the } \\
\text { Board of Oil is required to } \\
\text { consult with the Department of } \\
\text { Environmental Quality); (ii) a } \\
\text { mechanism exists to transfer } \\
\text { liability to the state and the } \\
\text { conclusion of the post-closure } \\
\text { period (envisioned to be ten } \\
\text { years); and (iii) pore space } \\
\text { ownership is not addressed. }\end{array}$ & $\begin{array}{l}\text { Feb } 21^{\text {st }}-\text { first reading } \\
\text { Feb } 23^{\text {rd }}-\text { referred to } \\
\text { Energy } \& \\
\text { Telecommunications } \\
\text { Mar } 5^{\text {th }}-\text { hearing } \\
\text { Mar } 18^{\text {th }}-\text { passed } \\
\text { Energy \& } \\
\text { Telecommunications } \\
\text { Mar } 24^{\text {th }}-\text { passed the } \\
\text { House and transmitted } \\
\text { to the Senate } \\
\text { Mar } 24^{\text {th }}-\text { referred to } \\
\text { Federal Relations, } \\
\text { Energy and } \\
\text { Telecommunications } \\
\text { Apr } 8^{\text {th }}-\text { Amendments } \\
\text { have been offered. One } \\
\text { that gives pore space } \\
\text { ownership to the surface } \\
\text { landowners. The } \\
\text { Governor now supports } \\
\text { the measure, after } \\
\text { previously threatening } \\
\text { veto over lack of pore } \\
\text { space ownership. } \\
\text { Apr } 24^{\text {th }} \text {-Bill passes } \\
\text { House as amended, } \\
43-7 . \text { Moves to Senate }\end{array}$ & $\begin{array}{l}\text { http://data.opi.mt.gov/bills } \\
\text { /2009/billpdf/SB0498.pdf }\end{array}$ \\
\hline
\end{tabular}




\begin{tabular}{|c|c|c|c|}
\hline State & Legislation & Status & Link to Bill Text/News \\
\hline New Mexico & $\begin{array}{l}\text { Introduced on February } 16, \\
2009, \text { HB } 790 \text { authorizes } \\
\text { creation of a regulatory regime } \\
\text { for CCS rooted in the Oil } \\
\text { Conservation Commission and } \\
\text { the Oil Conservation Division of } \\
\text { the Energy, Minerals and } \\
\text { Natural Resources Department. } \\
\text { The legislation: (i) does not } \\
\text { envision the storage and EOR } \\
\text { may occur concurrently, and (ii) } \\
\text { endeavors to clarify pore space } \\
\text { ownership rights. }\end{array}$ & $\begin{array}{l}\text { Mar } 24^{\text {th }}-- \text { pending } \\
\text { before the House } \\
\text { Energy and Natural } \\
\text { Resources Committee } \\
\text { Note: We understand } \\
\text { that HB } 790 \text { has been } \\
\text { effectively tabled, with } \\
\text { the focus now on SB } \\
208 \text { (discussed below) }\end{array}$ & $\begin{array}{l}\text { http://www.nmlegis.gov } / 1 \\
\text { cs/ session.aspx?chamber } \\
=\text { H\&legtype }=\text { B\&legno }=\% \\
\text { 20790\&year }=09\end{array}$ \\
\hline New Mexico & $\begin{array}{l}\text { Introduced on January } 22,2009 \\
\text { and subsequently amended in } \\
\text { committee and on the Senate } \\
\text { floor, SB } 208 \text { establishes pore } \\
\text { space ownership rights. } \\
\text { Ownership of the pore space is } \\
\text { vested in the surface estate, } \\
\text { unless previously severed. The } \\
\text { rights of mineral owners and } \\
\text { lessees are recognized, however, } \\
\text { in that they have the right to use } \\
\text { pore space as necessary to } \\
\text { produce native oil, gas or other } \\
\text { minerals, including rights to } \\
\text { inject fluids for EOR. Injected } \\
\text { CO }{ }_{2} \text { remains the property and } \\
\text { responsibility of the person } \\
\text { conducting the injection, unless } \\
\text { transferred to another person or } \\
\text { released from the reservoir by } \\
\text { another person. }\end{array}$ & $\begin{array}{l}\text { Mar } 17^{\text {th }}-\text { passed the } \\
\text { Senate. } \\
\text { Mar } 18^{\text {th }}-\text { referred to } \\
\text { House Business \& } \\
\text { Industry Committee. } \\
\text { Apr } 1^{\text {st }}-\text { Died. }\end{array}$ & $\frac{\text { http://www.nmlegis.gov/S }}{\text { essions/09\%20Regular/bil }}$ \\
\hline New York & $\begin{array}{l}\text { Introduced on February } 20 \text {, } \\
\text { 2009, A05836: (i) authorizes the } \\
\text { Department of Environmental } \\
\text { Conservation to permit storage } \\
\text { sites; (ii) declares that pore } \\
\text { space is owned by the surface } \\
\text { estate; and (iii) grants regulated } \\
\text { public utilities and municipal } \\
\text { electric corporations } \\
\text { condemnation rights for pore } \\
\text { space. }\end{array}$ & $\begin{array}{l}\text { Mar } 20^{\text {th }} \text {-referred to } \\
\text { Environmental } \\
\text { Conservation }\end{array}$ & $\begin{array}{l}\text { http://assembly.state.ny.us } \\
\text { /leg/?bn=A05836\&sh=t }\end{array}$ \\
\hline
\end{tabular}




\begin{tabular}{|c|c|c|c|}
\hline State & Legislation & Status & Link to Bill Text/News \\
\hline $\begin{array}{l}\text { North } \\
\text { Dakota }\end{array}$ & $\begin{array}{l}\text { Introduced on January } 6,2009 \text {, } \\
\text { SB } 2095 \text { establishes a regulatory } \\
\text { framework for CCS. The } \\
\text { Industrial Commission is the } \\
\text { permitting authority. Permitting } \\
\text { requirements are established. } \\
\text { Unitization is provided. Stored } \\
\mathrm{CO}_{2} \text { is deemed not to be a } \\
\text { pollutant and does not constitute } \\
\text { a nuisance. Operators pay per- } \\
\text { ton storage fees, which are used } \\
\text { to fund a Carbon Dioxide } \\
\text { Storage Facility Administrative } \\
\text { Fund. The storage operator has } \\
\text { title to the CO } \mathrm{O}_{2} \text { and is } \\
\text { responsible for it, until such } \\
\text { time as the Industrial } \\
\text { Commission issues a certificate } \\
\text { of project completion, as which } \\
\text { time title to and responsibility } \\
\text { for the } \mathrm{CO}_{2} \text { transfers to the state. } \\
\text { With respect to whether CO }{ }_{2}^{-} \\
\text {EOR and storage may occur } \\
\text { concurrently (without subject } \\
\text { EOR to the full weight of the } \\
\text { storage rules), SB } 2095 \text { provides } \\
\text { that EOR may convert to } \\
\text { storage, but also states that the } \\
\text { Industrial Commission may } \\
\text { tailor or waive specific } \\
\text { requirements on a case-by-case } \\
\text { basis. }\end{array}$ & $\begin{array}{l}\text { Feb } 4^{\text {th }}-\text { passed the } \\
\text { Senate. } \\
\text { Mar } 11^{\text {th }}-\text { passed the } \\
\text { House. } \\
\text { Apr } 8^{\text {th }} \text { - Signed by } \\
\text { Governor. }\end{array}$ & $\begin{array}{l}\text { http://www.legis.nd.gov/a } \\
\text { ssembly/61-2009/bill- } \\
\text { text/JQTA0200.pdf }\end{array}$ \\
\hline $\begin{array}{l}\text { North } \\
\text { Dakota }\end{array}$ & $\begin{array}{l}\text { Introduced on January } 14,2009 \text {, } \\
\text { SB } 2221 \text { creates a credit against } \\
\text { coal conversion privilege taxes } \\
\text { for facilities that achieve a } \\
\text { required level of } \mathrm{CO}_{2} \text { capture. }\end{array}$ & $\begin{array}{l}\text { Feb } 18^{\text {th }}-\text { passed the } \\
\text { Senate } \\
\text { Feb } 26^{\text {th }}-\text { referred to } \\
\text { Finance } \& \text { Taxation } \\
\text { Mar } 10^{\text {th }}-\text { hearing } \\
\text { Mar } 11^{\text {th }}-\text { referred to } \\
\text { Appropriations } \\
\text { Apr } 22^{\text {nd }}-\text { Signed by } \\
\text { Governor. }\end{array}$ & $\begin{array}{l}\text { http://www.legis.nd.gov/a } \\
\text { ssembly/61-2009/bill- } \\
\text { text/JAQD0400.pdf }\end{array}$ \\
\hline
\end{tabular}




\begin{tabular}{|c|c|c|c|}
\hline State & Legislation & Status & Link to Bill Text/News \\
\hline $\begin{array}{l}\text { North } \\
\text { Dakota }\end{array}$ & $\begin{array}{l}\text { Introduced on January } 6,2009 \text {, } \\
\text { SB } 2034 \text { creates a permanent } \\
\text { exemption from the oil } \\
\text { extraction tax for incremental } \\
\text { production from a tertiary } \\
\text { recovery project that uses } \mathrm{CO}_{2} \text {. }\end{array}$ & $\begin{array}{l}\text { Feb } 13^{\text {th }}-\text { passed the } \\
\text { Senate } \\
\text { March } 2^{\text {nd }}-\text { passed the } \\
\text { House } \\
\text { Mar } 4^{\text {th }}-\text { Signed by } \\
\text { House Speaker } \\
\text { Mar } 5^{\text {th }}-\text { Signed by } \\
\text { Senate President } \\
\text { Apr } 8^{\text {th }}-\text { Signed by } \\
\text { Governor. }\end{array}$ & $\begin{array}{l}\underline{\text { http://www.legis.nd.gov/a }} \\
\underline{\text { ssembly/61-2009/bill- }} \\
\text { text/JAIP0300.pdf }\end{array}$ \\
\hline $\begin{array}{l}\text { North } \\
\text { Dakota }\end{array}$ & $\begin{array}{l}\text { Introduced on January } 6,2009 \text {, } \\
\text { SB } 2139 \text { defines pore space and } \\
\text { vests title in it to the surface } \\
\text { estate. }\end{array}$ & $\begin{array}{l}\text { Feb } 4^{\text {th }}-\text { passed the } \\
\text { Senate } \\
\text { Mar } 11^{\text {th }}-\text { passed the } \\
\text { House, as amended } \\
\text { Mar } 23^{\text {rd }}-\text { passed the } \\
\text { Senate, as amended } \\
\text { Apr } 8^{\text {th }}-\text { Signed by } \\
\text { Governor }\end{array}$ & $\begin{array}{l}\underline{\text { http://www.legis.nd.gov/a }} \\
\underline{\text { ssembly/61-2009/bill- }} \\
\text { text/JQTB0300.pdf }\end{array}$ \\
\hline Oklahoma & $\begin{array}{l}\text { Introduced on February 2, 2009, } \\
\text { SB } 492 \text { authorizes the } \\
\text { Department of Environmental } \\
\text { Quality to issue CCS permits } \\
\text { under certain terms and } \\
\text { conditions. CO } \text { CO }_{2} \text { EOR is not } \\
\text { included (unless the operations } \\
\text { are converted to storage). The } \\
\text { resulting regulations would } \\
\text { likely broadly mirror EPA's } \\
\text { forthcoming UIC rule. }\end{array}$ & $\begin{array}{l}\text { Feb } 3^{\text {rd }}-\text { referred to } \\
\text { Energy \& Environment }\end{array}$ & $\begin{array}{l}\frac{\text { http://webserver1.lsb.state }}{\text { ok.us/WebBillStatus/mai }} \\
\underline{\text { n.html }}\end{array}$ \\
\hline Oklahoma & $\begin{array}{l}\text { Introduced on February 2, 2009, } \\
\text { SB } 610 \text { authorizes the } \\
\text { Department of Environmental } \\
\text { Quality to issue CCS permits } \\
\text { under certain terms and } \\
\text { conditions. The Corporation } \\
\text { Commission is authorized to } \\
\text { regulate storage operators and } \\
\text { pipelines as public utilities. } \\
\mathrm{CO}_{2} \text {-EOR is not subject to the } \\
\text { scheme "where the sole } \\
\text { purpose" is enhanced oil. } \\
\text { Storage and pipeline operators } \\
\text { are provided eminent domain } \\
\text { rights. }\end{array}$ & $\begin{array}{l}\text { Mar } 10^{\text {th }}-\text { passed the } \\
\text { Senate, as amended } \\
\text { Mar } 17^{\text {th }}-\text { referred to } \\
\text { Energy \& Utility } \\
\text { Regulation } \\
\text { Apr } 8^{\text {th }}-\text { Amended } \\
\text { committee substitute } \\
\text { Energy and Utility } \\
\text { Regulation Committee. } \\
\text { Title Restored. } \\
\text { Apr } 16^{\text {th }}-\text { Passed } \\
\text { House, Signed and Sent } \\
\text { to Senate. } \\
\text { Apr } 22^{\text {nd }}-\text { Senate } \\
\text { conference requested. }\end{array}$ & $\begin{array}{l}\underline{\text { http://webserver1.lsb.state }} \\
\text {.ok.us/WebBillStatus/mai } \\
\underline{\text { n.html }}\end{array}$ \\
\hline
\end{tabular}




\begin{tabular}{|c|c|c|c|}
\hline State & Legislation & Status & Link to Bill Text/News \\
\hline Oklahoma & $\begin{array}{l}\text { Introduced on February 2, 2009, } \\
\text { SB } 679 \text { extends the life of the } \\
\text { Oklahoma Geologic Storage of } \\
\text { Carbon Dioxide Task Force } \\
\text { until December } 1,2009 .\end{array}$ & $\begin{array}{l}\text { Mar } 5^{\text {th }}-\text { passed the } \\
\text { Senate } \\
\text { Mar } 18^{\text {th }}-\text { referred to } \\
\text { Energy \& Utility } \\
\text { Regulation } \\
\text { Apr } 2^{\text {nd }}-\text { Do pass. } \\
\text { Apr } 9^{\text {th }}-\text { Third reading, } \\
\text { ayes } 86, \text { nays } 3 . \\
\text { Referred for } \\
\text { engrossment. } \\
\text { Apr } 13^{\text {th }}-\text { Engrossed } \\
\text { and Signed, moved to } \\
\text { Senate. House } \\
\text { amendment's read. }\end{array}$ & $\begin{array}{l}\text { http://webserver1.lsb.state } \\
\text { ok.us/WebBillStatus/mai } \\
\text { n.html } \\
\text { Note: The task force } \\
\text { continues to meet and is } \\
\text { working through } \\
\text { jurisdictional issues }\end{array}$ \\
\hline Oregon & $\begin{array}{l}\text { Introduced on March } 4,2009 \text {, } \\
\text { H.J.M. } 11 \text { calls on the President } \\
\text { and Congress of the U.S. to } \\
\text { ensure that revenue resulting } \\
\text { from forestry sequestration on } \\
\text { federal lands is shared with the } \\
\text { states. }\end{array}$ & $\begin{array}{l}\text { Mar } 6^{\text {th }}-\text { referred to } \\
\text { House Committee on } \\
\text { Environment and Water. } \\
\text { May1st - Public hearing } \\
\text { and work session } \\
\text { scheduled. }\end{array}$ & $\begin{array}{l}\frac{\text { http://www.leg.state.or.us/ }}{\text { 09reg/measpdf/hjm1.dir/h }} \\
\text { jm0011.intro.pdf }\end{array}$ \\
\hline Pennsylvania & $\begin{array}{l}\text { Introduced on March } 19,2009 \text {, } \\
\text { SB } 92 \text { amends the Alternative } \\
\text { Energy Portfolio Standards Act } \\
\text { to add "advanced coal } \\
\text { combustion with limited carbon } \\
\text { emissions" as a type of } \\
\text { alternative energy source and } \\
\text { providing minimum retail power } \\
\text { sales percentages from such } \\
\text { facilities over time. } \\
\text { "Advanced coal combustion } \\
\text { with limited carbon emissions" } \\
\text { means the production of electric } \\
\text { power from a facility that: (i) is } \\
\text { fueled by coal or gas derived } \\
\text { from an advanced coal } \\
\text { gasification plant; (ii) captures } \\
\text { and permanently sequesters } \\
\text { increasing percentages of } \mathrm{CO}_{2} \\
\text { over time; and (iii) has been } \\
\text { designed to accommodate the } \\
\text { required additional processing } \\
\text { equipment to produce power } \\
\text { with a maximum of } 1,000 \\
\text { pounds of } \mathrm{CO}_{2} \text { emissions per } \\
\text { megawatt hour. }\end{array}$ & $\begin{array}{l}\frac{\text { SB 92 }}{\text { Mar } 19^{\text {th }}-\text { referred to }} \\
\text { Environmental } \\
\text { Resources and Energy } \\
\underline{\text { HB } 80} \\
\text { Mar } 12^{\text {th }}-\text { referred to } \\
\text { Environmental } \\
\text { Resources and Energy }\end{array}$ & $\begin{array}{l}\text { SB 92: } \\
\text { http://www.legis.state.pa. } \\
\text { us/CFDOCS/Legis/PN/Pu } \\
\text { blic/btCheck.cfm?txtType } \\
\text { =PDF\&sessYr=2009\&ses } \\
\text { sInd=0\&billBody=S\&bill } \\
\underline{\text { Typ=B\&billNbr=0092\&p }} \\
\underline{n=0683} \\
\text { HB 80: } \\
\underline{\text { http://www.legis.state.pa. }} \\
\text { us/CFDOCS/Legis/PN/Pu } \\
\text { blic/btCheck.cfm?txtType } \\
=\text { PDF\&sessYr=2009\&ses } \\
\underline{\text { sInd=0\&billBody=H\&bill }} \\
\text { Typ=B\&billNbr=0080\&p } \\
\underline{\text { n=1000 }}\end{array}$ \\
\hline
\end{tabular}




\begin{tabular}{|c|c|c|c|}
\hline State & Legislation & Status & Link to Bill Text/News \\
\hline & $\begin{array}{l}\text { The CCS requirement is relieved } \\
\text { if a storage network is not } \\
\text { available by June } 1,2015 \text {. Retail } \\
\text { sales requirements are also } \\
\text { relieved if it is determined by } \\
\text { December } 15,2015 \text { that } \\
\text { "advanced coal combustion } \\
\text { [facilities] with limited carbon } \\
\text { emissions" have not commenced } \\
\text { construction. } \\
\text { The Department of } \\
\text { Conservation \& Natural } \\
\text { Resources is directed to develop } \\
\text { and operate a "carbon dioxide } \\
\text { sequestration network" on state } \\
\text { land or land that DCNR has } \\
\text { acquired. Only CO }{ }_{2} \text { generated } \\
\text { within Pennsylvania may be } \\
\text { stored on such sites. DCNR is } \\
\text { authorized to collect fees to } \\
\text { operate the CCS network. } \\
\text { DCNR can enter into a contract } \\
\text { to have a third party run the } \\
\mathrm{CCS} \text { network. More broadly, } \\
\text { DCNR must issue regulations to } \\
\text { govern CCS. } \\
\mathrm{CO}_{2} \text {-EOR is excluded from and } \\
\text { cannot be deemed part of the } \\
\mathrm{CCS} \text { network. }_{\text {Pennsylvania takes title to and is }} \\
\text { responsible for all CO }{ }_{2} \text { stored } \\
\text { within the CCS network. } \\
\text { The companion bill is HB } 80 .\end{array}$ & & \\
\hline $\begin{array}{l}\text { South } \\
\text { Dakota }\end{array}$ & $\begin{array}{l}\text { Introduced on January } 27,2009, \\
\text { HB } 1129 \text { requires the Public } \\
\text { Utilities Commission to regulate } \\
\mathrm{CO}_{2} \text { pipelines. }\end{array}$ & $\begin{array}{l}\text { Feb } 24^{\text {th }}-\text { passed the } \\
\text { House } \\
\text { Mar } 3^{\text {rd }}-\text { passed the } \\
\text { Senate } \\
\text { Mar } 11^{\text {th }}-\text { signed by the } \\
\text { Governor }\end{array}$ & $\begin{array}{l}\text { http://legis.state.sd.us/sess } \\
\underline{\text { pons/2009/Bills/HB1129P. }}\end{array}$ \\
\hline
\end{tabular}




\begin{tabular}{|c|c|c|c|}
\hline State & Legislation & Status & Link to Bill Text/News \\
\hline Texas & $\begin{array}{l}\text { Introduced on March } 13,2009, \\
\text { SJR } 39 \text { proposes a constitutional } \\
\text { amendment authorizing the } \\
\text { issuance of generation } \\
\text { obligation bonds to provide and } \\
\text { guarantee loans to encourage } \\
\text { "advanced clean energy } \\
\text { projects", which in turn must } \\
\text { "capture[] not less than } 50 \\
\text { percent of any carbon dioxide } \\
\text { produced by the combustion of } \\
\text { fuel and sequester[] that } \\
\text { captured carbon dioxide by } \\
\text { geologic storage or other } \\
\text { means". "Geologic storage" } \\
\text { means the "underground storage } \\
\text { of carbon dioxide in a suitable } \\
\text { geologic formation, including } \\
\text { storage that is accomplished in } \\
\text { conjunction with an enhanced } \\
\text { oil recovery project." } \\
\text { SJR } 39 \text { is being implemented } \\
\text { via two companion bills: SB } \\
2111 \text { and HB } 2811 . \\
\text { SB } 2111 \text { and HB } 2811 \text { also } \\
\text { specify that the Railroad } \\
\text { Commission retains jurisdiction } \\
\text { over CO } \text {-EOR operations that } \\
\text { include both oil production and } \\
\text { storage activities. }\end{array}$ & 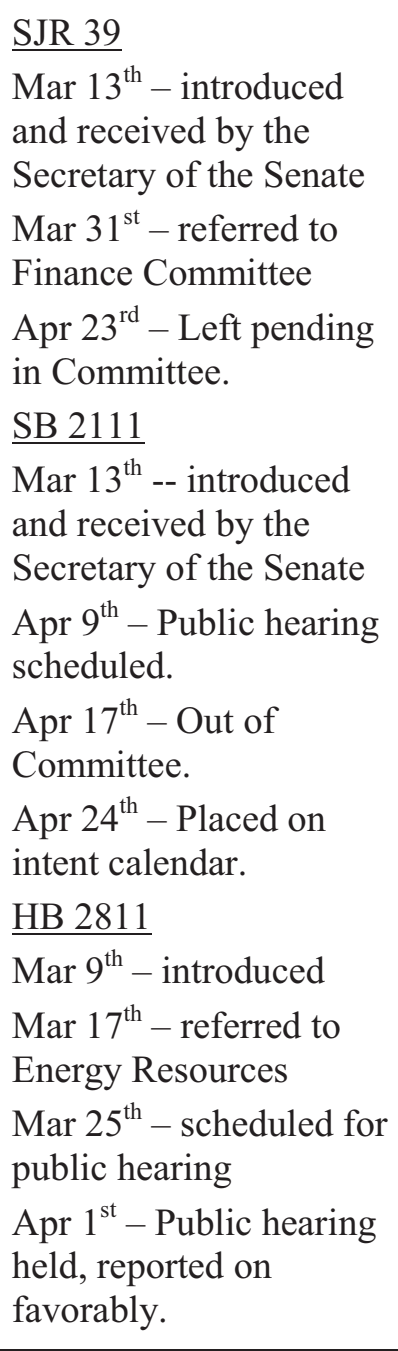 & $\begin{array}{l}\text { SJR 39: } \\
\text { http://www.legis.state.tx.u } \\
\text { s/BillLookup/Text.aspx?L } \\
\text { egSess=81R\&Bill=SJR39 } \\
\text { SB 2111: } \\
\text { http://www.legis.state.tx.u } \\
\text { s/BillLookup/Text.aspx?L } \\
\text { egSess=81R\&Bill=SB211 } \\
\underline{1} \\
\text { HB 2811: } \\
\text { http://www.legis.state.tx.u } \\
\underline{\text { S/BillLookup/Text.aspx?L }} \\
\underline{\text { egSess=81R\&Bill=HB28 }} \\
\underline{11}\end{array}$ \\
\hline Texas & $\begin{array}{l}\text { Introduced on December } 22 \text {, } \\
2008, \mathrm{HB} 469 \text { provides tax } \\
\text { incentives to organizations that } \\
\text { participate in R\&D activities } \\
\text { related to a "clean energy } \\
\text { project", defined as a coal-fired } \\
\text { power plant that: (i) can } \\
\text { generate at least } 200 \mathrm{MW} \text {; (ii) } \\
\text { uses IGCC technology; and (iii) } \\
\text { is capable of capturing and } \\
\text { permanently sequestering at } \\
\text { least } 60 \% \text { of the facility } \mathrm{CO}_{2} \\
\text { emissions. } \\
\text { A franchise tax credit not to } \\
\text { exceed } \$ 100 \mathrm{M} \text { per organization } \\
\text { is provided. The tax credits } \\
\text { could be assigned to a taxable } \\
\text { entity. }\end{array}$ & $\begin{array}{l}\underline{\text { HB } 469} \\
\text { Feb } 19^{\text {th }}-\text { referred to } \\
\text { Energy Resources } \\
\text { Mar } 25^{\text {th }}-\text { scheduled for } \\
\text { public hearing } \\
\text { Apr } 1^{\text {st }}-\text { public hearing } \\
\text { held. Substitute } \\
\text { considered and } \\
\text { amended. Reported } \\
\text { favorably as substituted. } \\
\text { Apr } 17^{\text {th }}-\text { Committee } \\
\text { report sent to calendars } \\
\text { on. Out of House } \\
\text { Committee. } \\
\underline{\text { SB } 483} \\
\text { Mar } 13^{\text {th }}-\text { referred to } \\
\text { Finance }\end{array}$ & $\begin{array}{l}\text { HB 469: } \\
\text { http://www.legis.state.tx.u } \\
\text { s/tlodocs/81R/billtext/pdf/ } \\
\text { HB00469I.pdf } \\
\text { SB 483: } \\
\text { http://www.legis.state.tx.u } \\
\text { s/BillLookup/Text.aspx?L } \\
\text { egSess=81R\&Bill=SB483 }\end{array}$ \\
\hline
\end{tabular}




\begin{tabular}{|c|c|c|c|}
\hline State & Legislation & Status & Link to Bill Text/News \\
\hline & $\begin{array}{l}\text { The Bureau of Economic } \\
\text { Geology must monitor measure } \\
\text { and verify the sequestered } \mathrm{CO}_{2} \\
\text { for the first three clean energy } \\
\text { projects. } \\
\mathrm{HB} 469 \text { amends the tax code to } \\
\text { reduce the oil production tax } \\
\text { rate from } 4.6 \% \text { to } 1.15 \% \text { for } \\
\text { EOR using } \mathrm{CO}_{2} \text { from a clean } \\
\text { energy project. The credit lasts } \\
\text { for the later to occur of thirty } \\
\text { years or the date upon which } \\
\text { EPA determines that CO } \mathrm{O}_{2} \text { is a } \\
\text { pollutant. The amount } \\
\text { sequestered must be certified by } \\
\text { the Railroad Commission (in the } \\
\text { case of EOR) or TCEQ (in other } \\
\text { cases) based upon substantial } \\
\text { evidence that the "planned } \\
\text { sequestration program will } \\
\text { ensure that at least } 60 \text { percent of } \\
\text { the carbon dioxide sequestered } \\
\ldots \text { will remain sequestered for at } \\
\text { least } 500 \text { years." } \\
\text { Finally, SB } 483 \text { contains similar } \\
\text { provisions but is not a formal } \\
\text { companion bill. Because of their } \\
\text { overlaps, we are reporting both } \\
\text { bills together here. }\end{array}$ & $\begin{array}{l}\text { Apr } 9^{\text {th }}-\text { public hearing } \\
\text { held. Left pending in } \\
\text { committee. }\end{array}$ & \\
\hline Texas & $\begin{array}{l}\text { Introduced on January } 29,2009 \text {, } \\
\text { SB } 16 \text { amends the definition of } \\
\text { "advanced clean energy project" } \\
\text { in a manner similar (CCS } \\
\text { requirement, etc.) to that } \\
\text { provided under SB } 2111 \text { and HB } \\
2811 \text {, discussed above. } \\
\text { TCEQ is authorized to provide } \\
\text { grants or other financial } \\
\text { incentives for eligible projects to } \\
\text { offset the incremental cost of } \\
\text { emission reductions. Eligible } \\
\text { projects include "advanced } \\
\text { clean energy projects." Except } \\
\text { for projects using Texas natural } \\
\text { resources, projects incorporating } \\
\text { CCS are not provided a } \\
\text { preference. }\end{array}$ & $\begin{array}{l}\text { Feb } 10^{\text {th }}-\text { referred to } \\
\text { Natural Resources } \\
\text { Mar } 19^{\text {th }}-\text { public } \\
\text { hearing } \\
\text { Apr } 8^{\text {th }}-\text { amendments } \\
\text { heard and voted on. } \\
\text { Passed to engrossment } \\
\text { as amended. } \\
\text { Apr } 22^{\text {nd }}-\text { Moved to } \\
\text { House, hearing } \\
\text { scheduled for } 4 / 29 \text { in } \\
\text { House Committee on } \\
\text { Environmental } \\
\text { Regulation. }\end{array}$ & $\begin{array}{l}\text { http://www.legis.state.tx.u } \\
\text { S/tlodocs/81R/billtext/pdf/ } \\
\text { SB00016I.pdf }\end{array}$ \\
\hline
\end{tabular}




\begin{tabular}{|c|c|c|c|}
\hline State & Legislation & Status & Link to Bill Text/News \\
\hline Texas & $\begin{array}{l}\text { Introduced on February 25, } \\
2009, \mathrm{HB} 1796 \text { requires TCEQ } \\
\text { to work with the Bureau of } \\
\text { Economic Geology to do a pilot } \\
\text { study to identify locations and } \\
\text { develop standards and rules for } \\
\text { the offshore sequestration of } \\
\mathrm{CO}_{2} \text {. } \\
\text { Thereafter, TCEQ would use the } \\
\text { study results to select a location } \\
\text { for an offshore repository; a } \\
\text { storage fee mechanism is also } \\
\text { envisioned. } \\
\text { TCEQ, on behalf of the state of } \\
\text { Texas, would take title to } \\
\text { injected } \mathrm{CO}_{2} \text {. }\end{array}$ & $\begin{array}{l}\text { Mar } 4^{\text {th }}-\text { referred to } \\
\text { Environmental } \\
\text { Regulation } \\
\text { Mar } 25^{\text {th }}-\text { hearing held. } \\
\text { Left pending in } \\
\text { committee. } \\
\text { Apr } 9^{\text {th }}-\text { Reported } \\
\text { favorably in Committee. } \\
\text { Apr } 22^{\text {nd }}-\text { Committee } \\
\text { report sent to calendars } \\
\text { and is now out of } \\
\text { committee by vote of } \\
9-0 .\end{array}$ & $\begin{array}{l}\text { http://www.legis.state.tx.u } \\
\text { s/tlodocs/81R/billtext/pdf/ } \\
\underline{\text { HB01796I.pdf }}\end{array}$ \\
\hline Texas & $\begin{array}{l}\text { Introduced on March 5, } 2009 \text {, } \\
\text { SB } 1387 \text { provides that TCEQ is } \\
\text { responsible for CCS regulation } \\
\text { and permitting, except for } \mathrm{CO}_{2^{-}} \\
\text {EOR wells, which remain under } \\
\text { authority of the Railroad } \\
\text { Commission. The Railroad } \\
\text { Commission is also given } \\
\text { authority to regulate saline } \\
\text { formations directly above or } \\
\text { below an EOR reservoir. It is } \\
\text { envisioned that TCEQ and the } \\
\text { Railroad Commission will } \\
\text { cooperate on permitting, and to } \\
\text { that end, the agencies must enter } \\
\text { into a MOU. } \\
\text { CCS regulations must be } \\
\text { consistent with and not more } \\
\text { stringent than whatever rules } \\
\text { emerge from EPA. } \\
\text { Injected } \mathrm{CO}_{2} \text { is declared to be } \\
\text { the personal property of the } \\
\text { storage operator. } \\
\text { Previously injected CO } \mathrm{CO}_{2} \text { may be } \\
\text { extracted for later commercial or } \\
\text { industrial use, with the approval } \\
\text { of TCEQ. } \\
\text { The companion bill is HB } 2669 \text {. }\end{array}$ & $\begin{array}{l}\frac{\text { SB } 1387}{\text { Mar } 17^{\text {th }}-\text { referred to }} \\
\text { Natural Resources } \\
\text { Mar } 26^{\text {th }}-\text { hearing held. } \\
\text { Left pending in } \\
\text { committee. } \\
\text { Apr } 22^{\text {nd }} \text {-Passed } \\
\text { Senate by vote of } 30-0 . \\
\text { Moves to House. } \\
\text { HB } 2669 \\
\text { Mar } 6^{\text {th }}-\text { introduced } \\
\text { Mar } 16^{\text {th }}-\text { referred to } \\
\text { Environmental } \\
\text { Regulation } \\
\text { Mar } 25^{\text {th }}-\text { hearing held, } \\
\text { left pending in } \\
\text { committee. } \\
\text { Apr } 15^{\text {th }} \text {-Reported } \\
\text { favorably in committee } \\
\text { by vote of } 8-0 .\end{array}$ & $\begin{array}{l}\text { SB 1387: } \\
\text { http://www.legis.state.tx.u } \\
\text { s/tlodocs/81R/billtext/pdf/ } \\
\text { SB01387I.pdf } \\
\text { HB 2669: } \\
\text { http://www.legis.state.tx.u } \\
\underline{\text { S/BillLookup/Text.aspx?L }} \\
\underline{\text { egSess=81R\&Bill=HB26 }} \\
\underline{69}\end{array}$ \\
\hline
\end{tabular}




\begin{tabular}{|c|c|c|c|}
\hline State & Legislation & Status & Link to Bill Text/News \\
\hline Utah & $\begin{array}{l}\text { Introduced on January } 30,2009 \text {, } \\
\text { HJR } 12 \text { expresses the } \\
\text { Legislature's support for: } \\
\text { (i) producing hydrogen from } \\
\text { coal with CCS; (ii) encouraging } \\
\text { the Public Service Commission } \\
\text { to consider authorizing recovery } \\
\text { of cost-effective and prudently } \\
\text { incurred costs that reduce } \\
\text { carbon emissions; and (iii) } \\
\text { encouraging the PSC to consider } \\
\text { hydrogen production from coal } \\
\text { with CCS to be a reasonable } \\
\text { investment for protecting the } \\
\text { long-term interests of Utah's } \\
\text { utility rate payers. }\end{array}$ & $\begin{array}{l}\text { Feb } 19^{\text {th }}-\text { passed the } \\
\text { House } \\
\text { Mar } 5^{\text {th }}-\text { passed the } \\
\text { Senate } \\
\text { Mar } 18^{\text {th }}-\text { sent to the } \\
\text { Lieutenant Governor }\end{array}$ & $\begin{array}{l}\text { http://le.utah.gov/ 2009/b } \\
\text { ills/hbillint/hjr012s01.pdf }\end{array}$ \\
\hline $\begin{array}{l}\text { West } \\
\text { Virginia }\end{array}$ & $\begin{array}{l}\text { Introduced on February } 26, \\
2009, \text { HB } 2860 \text { expresses the } \\
\text { Legislature's support for CCS } \\
\text { and: } \\
\text { (i) Directs the Department of } \\
\text { Environmental Protection to } \\
\text { issue regulations governing } \\
\text { CCS; } \\
\text { (ii) Sets forth requirements for } \\
\text { the regulations (basically } \\
\text { mirrors federal UIC); } \\
\text { (iii) Establishes a Carbon } \\
\text { Dioxide Sequestration Working } \\
\text { Group to develop, among other } \\
\text { things, a long-term CCS strategy } \\
\text { for West Virginia; and } \\
\text { (iv) Declares pore space to be an } \\
\text { attribute of the surface estate. } \\
\text { CO }{ }_{2} \text {-EOR is not included in the } \\
\text { storage scheme; instead, EOR } \\
\text { operators are given the chance } \\
\text { to convert their operations into } \\
\text { storage. HB } 2860 \text { states, } \\
\text { however, that nothing in the bill } \\
\text { is intended to impede or impair } \\
\text { an EOR operator from } \\
\text { generating carbon credits. } \\
\text { SB } 396 \text { is the companion bill. }\end{array}$ & $\begin{array}{l}\frac{\text { HB } 2860}{\text { Feb } 26^{\text {th }}}-\text { sent to } \\
\text { Judiciary } \\
\text { Mar } 18^{\text {th }}-\text { passed } \\
\text { Judiciary } \\
\text { Mar } 18^{\text {th }}-\text { sent to } \\
\text { Finance } \\
\text { Apr } 7-\text { referred to } \\
\text { Judiciary. On } 2^{\text {nd }} \\
\text { reading, it was amended } \\
\text { and recommended Do } \\
\text { Pass. } \\
\text { Apr } 10^{\text {th }}-\text { Passed } \\
\text { Senate. } \\
\text { Apr } 11^{\text {th }}-\text { Awaiting } \\
\text { Governor's signature. } \\
\text { SB } 396 \\
\text { Feb } 26^{\text {th }}-\text { introduced } \\
\text { Feb } 26^{\text {th }}-\text { to Energy, } \\
\text { Industry and Mining } \\
\text { (then Judiciary) }\end{array}$ & $\begin{array}{l}\text { HB 2860: } \\
\text { http://www.legis.state.wV. } \\
\frac{\text { us/Bill Text HTML/2009 }}{\text { SESSIONS/RS/amendm }} \\
\frac{\text { ents/HB2860\%20H\%20J }}{\text { UD\%20AM\%203- }} \\
\underline{18 \% 201 . h t m} \\
\text { SB 396: } \\
\underline{\text { http://www.legis.state.wv. }} \\
\underline{\text { us/Bill Text HTML/2009 }} \\
\text { SESSIONS/RS/Bills/sb3 } \\
\text { 96\%20intr.htm }\end{array}$ \\
\hline
\end{tabular}




\begin{tabular}{|c|c|c|c|}
\hline State & Legislation & Status & Link to Bill Text/News \\
\hline Wyoming & $\begin{array}{l}\text { Introduced on January } 13,2009 \text {, } \\
\text { HB } 56 \text { would prohibit the use of } \\
\text { hydrocarbon-containing pore } \\
\text { space for storage without the } \\
\text { written consent of the owner of } \\
\text { the oil and gas lease. }\end{array}$ & $\begin{array}{l}\text { Jan } 22^{\text {nd }}-\text { failed on third } \\
\text { reading }\end{array}$ & $\begin{array}{l}\frac{\text { http://legisweb.state.wy.us }}{2 \text { 2009/Introduced/HB0056 }} \\
\underline{\text { pdf }}\end{array}$ \\
\hline Wyoming & $\begin{array}{l}\text { Introduced on January } 13,2009 \text {, } \\
\text { HB } 57 \text { clarifies that a severed } \\
\text { mineral estate is dominant over } \\
\text { pore space storage rights. }\end{array}$ & $\begin{array}{l}\text { Jan } 20^{\text {th }}-\text { passed the } \\
\text { House } \\
\text { Feb } 17^{\text {th }}-\text { passed the } \\
\text { Senate } \\
\text { Feb } 26^{\text {th }}-\text { signed by the } \\
\text { Governor }\end{array}$ & $\begin{array}{l}\text { http://legisweb.state.wy.us } \\
\text { /2009/Enroll/HB0057.pdf }\end{array}$ \\
\hline Wyoming & $\begin{array}{l}\text { Introduced on January } 13,2009 \text {, } \\
\mathrm{HB} 58 \text { provides that injected } \\
\mathrm{CO}_{2} \text { is presumed to be owned } \\
\text { by, and thus liable for, the entity } \\
\text { that injected it. }\end{array}$ & $\begin{array}{l}\text { Jan } 20^{\text {th }}-\text { passed the } \\
\text { House } \\
\text { Feb } 19^{\text {th }}-\text { passed the } \\
\text { Senate } \\
\text { Feb } 26^{\text {th }}-\text { signed by the } \\
\text { Governor }\end{array}$ & $\begin{array}{l}\text { http://legisweb.state.wy.us } \\
\text { /2009/Enroll/HB0058.pdf }\end{array}$ \\
\hline Wyoming & $\begin{array}{l}\text { Introduced on January } 13,2009 \text {, } \\
\text { HB } 80 \text { establishes procedures } \\
\text { for the unitization of geologic } \\
\text { sequestration sites. }\end{array}$ & $\begin{array}{l}\text { Jan } 21^{\text {st }}-\text { passed the } \\
\text { House as amended } \\
\text { Feb } 19^{\text {th }}-\text { passed the } \\
\text { Senate as amended } \\
\text { Feb } 27^{\text {th }}-\text { signed by the } \\
\text { Governor }\end{array}$ & $\frac{\text { http://legisweb.state.wy.us }}{\text { /2009/Enroll/HB0080.pdf }}$ \\
\hline
\end{tabular}




\section{Active/High-Priority Regulatory Developments/Regulations}

\begin{tabular}{|c|c|c|c|}
\hline State & Regulations & Status & $\begin{array}{c}\text { Link to Regulatory } \\
\text { Text/News }\end{array}$ \\
\hline California & $\begin{array}{l}\text { On February } 24,2009 \text {, } \\
\text { CARB released its low } \\
\text { carbon fuel standard. } \\
\text { The LCFS acknowledges } \\
\text { that CCS could be used to } \\
\text { reduce the carbon intensity } \\
\text { of specific regulated fuels. }\end{array}$ & $\begin{array}{l}\text { April 23-24, 2009: } \\
\text { Public Hearing }\end{array}$ & $\begin{array}{l}\text { Staff Report: } \\
\text { http:/www.arb.ca.gov/fu } \\
\underline{\text { els/lcfs/0304091cfs_isor }} \\
\underline{\text { vol1.pdf }}\end{array}$ \\
\hline Kansas & $\begin{array}{l}\text { On January } 28,2009 \text {, the } \\
\text { Kansas Corporation } \\
\text { Commission proposed } \\
\text { regulations for the storage of } \\
\mathrm{CO}_{2} \text { in brine-filled } \\
\text { reservoirs. The regulations } \\
\text { do not apply to } \mathrm{CO}_{2} \text {-EOR } \\
\text { except for one provision that } \\
\text { purports to regulate drilling } \\
\text { through } \mathrm{CO}_{2} \text {-EOR } \\
\text { operations. } \\
\text { The regulations are being } \\
\text { implemented pursuant to } \mathrm{HB} \\
2419 \text {, discussed below. }\end{array}$ & $\begin{array}{l}\text { Public hearing will } \\
\text { be held on March } \\
26,2009 \text { and written } \\
\text { comments are due } \\
\text { on that date, too. }\end{array}$ & $\begin{array}{l}\frac{\text { http://www.kcc.state.ks.u }}{\text { s/conservation/hearing } 0} \\
\underline{32609 \cdot \mathrm{htm} \text { (notice of }} \\
\text { hearing) } \\
\underline{\text { http://kcc.ks.gov/conserv }} \\
\frac{\text { ation/proposed regs } 032}{\text { 609.pdf (proposed }} \\
\text { regulations) }\end{array}$ \\
\hline Oklahoma & $\begin{array}{l}\text { Oklahoma is in the midst of } \\
\text { implementing its geologic } \\
\text { storage offset program } \\
\text { pursuant to the Oklahoma } \\
\text { Carbon Sequestration } \\
\text { Enhancement Act. } \\
\text { Regulations have been issued } \\
\text { to implement the state's } \\
\text { novel carbon offset } \\
\text { certification program, which } \\
\text { includes geologic storage. } \\
\text { The Oklahoma Conservation } \\
\text { Commission has announced } \\
\text { that it shortly will start to } \\
\text { accept offset and verification } \\
\text { applications } \mathrm{CO}_{2} \text {-EOR } \\
\text { companies. }\end{array}$ & $\begin{array}{l}\text { Applications are } \\
\text { supposed to be made } \\
\text { available shortly on } \\
\text { the web site for the } \\
\text { Oklahoma } \\
\text { Conservation } \\
\text { Commission. }\end{array}$ & $\begin{array}{l}\frac{\text { http://www.ok.gov/conse }}{\text { rvation/Agency_Division }} \\
\frac{\text { s/Water Quality Divisio }}{\text { n/WQ Carbon Sequestra }} \\
\underline{\text { tion/Geologic Offsets /i }} \\
\underline{\text { ndex.html }}\end{array}$ \\
\hline
\end{tabular}




\begin{tabular}{|c|c|c|c|}
\hline State & Regulations & Status & $\begin{array}{c}\text { Link to Regulatory } \\
\text { Text/News }\end{array}$ \\
\hline Utah & $\begin{array}{l}\text { Utah's Carbon Capture and } \\
\text { Geologic Sequestration } \\
\text { Workgroup is meeting to } \\
\text { develop legislative } \\
\text { recommendations regarding } \\
\text { regulation of CCS. } \\
\text { The Workgroup consists of a } \\
\text { steering committee, three } \\
\text { subcommittees, an advisory } \\
\text { committee, and a stakeholder } \\
\text { group. } \\
\text { This is being done pursuant } \\
\text { to SB } 202 \text { Substitute, } \\
\text { described in greater detail } \\
\text { below. }\end{array}$ & $\begin{array}{l}\text { No new meetings } \\
\text { have been publicly } \\
\text { announced but we } \\
\text { encourage } \\
\text { companies with } \\
\text { interests in Utah to } \\
\text { contact the relevant } \\
\text { agencies. } \\
\text { The Workgroup } \\
\text { must provide a status } \\
\text { report to the } \\
\text { Legislature by } \\
\text { July } 1,2009 \text {. }\end{array}$ & $\begin{array}{l}\text { http://www.deq.utah.gov/ } \\
\text { News/2008/docs/New_W } \\
\text { orkgroup_Focuses_on_C } \\
\text { arbon_Capture_Regs_09 } \\
\text { 0308.pdf } \\
\text { http://www.climatechang } \\
\text { e.utah.gov/capture_seque } \\
\text { stration.htm } \\
\underline{\text { http://www.climatechang }} \\
\text { e.utah.gov/CCGS_in_Uta } \\
\text { h.htm }\end{array}$ \\
\hline
\end{tabular}




\section{Enacted Legislation/Other Developments of Note}

\begin{tabular}{|c|c|c|c|}
\hline State & $\begin{array}{l}\text { Legislation/Other } \\
\text { Developments }\end{array}$ & $\begin{array}{l}\text { When Signed Into } \\
\text { Law }\end{array}$ & Link to Bill Text/News \\
\hline California & $\begin{array}{l}\text { AB } 705 \\
\text { Would have authorized the } \\
\text { development of a CCS } \\
\text { regulatory regime in } \\
\text { California. } \\
\text { Although this effort failed, } \\
\text { we continue to report it here } \\
\text { because of its significance. }\end{array}$ & n/a: Died/stalled & 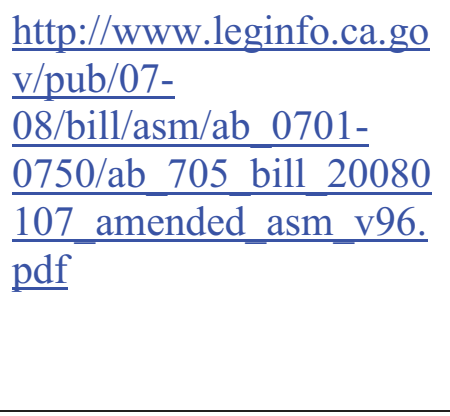 \\
\hline Colorado & $\begin{array}{l}\text { HB 06-1281 } \\
\text { Directs the Public Utilities } \\
\text { Commission to consider } \\
\text { proposals by Colorado } \\
\text { electric utilities to build one } \\
\text { or more demonstration } \\
\text { power plants using CCS- } \\
\text { equipped IGCC technology. }\end{array}$ & June 1, 2006 & $\begin{array}{l}\text { http://www.state.co.us/go } \\
\underline{\text { v_dir/leg_dir/olls/sl2006a }} \\
\text { /sl300.htm }\end{array}$ \\
\hline Colorado & $\begin{array}{l}\text { HB } 08-1164 \\
\text { Directs the Public Utilities } \\
\text { Commission to consider the } \\
\text { benefits of } \mathrm{CO}_{2} \text {-EOR when } \\
\text { utilities come forward with } \\
\text { CCS plans. }\end{array}$ & June 2, 2008 & 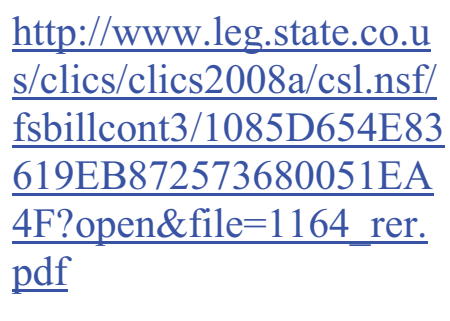 \\
\hline Connecticut & $\begin{array}{l}\text { HB } 5600 \\
\text { Authorizes the Department } \\
\text { of Environmental Protection } \\
\text { to issue CCS regulations. }\end{array}$ & June 2, 2008 & $\begin{array}{l}\frac{\mathrm{http}: / / \mathrm{www} \cdot c \mathrm{cga} \cdot \mathrm{ct} \cdot \mathrm{gov} / 20}{08 / \mathrm{TOB} / \mathrm{H} / 2008 \mathrm{HB}-} \\
\underline{05600-\mathrm{R} 00-\mathrm{HB} \cdot \mathrm{htm}} \\
\text { CT has not yet started } \\
\text { rulemaking proceedings } \\
\text { to implement this law }\end{array}$ \\
\hline Idaho & $\begin{array}{l}\text { Idaho Carbon Sequestration } \\
\text { Advisory Committee }\end{array}$ & $\mathrm{n} / \mathrm{a}$ & $\begin{array}{l}\text { The Committee is in the } \\
\text { early stages of } \\
\text { considering CCS-related } \\
\text { issues and opportunities } \\
\text { for the state. } \\
\text { http://www.scc.idaho.gov } \\
\text { /carbon\%20sequestration } \\
\% 20 \text { main.htm }\end{array}$ \\
\hline
\end{tabular}




\begin{tabular}{|c|c|c|c|}
\hline State & $\begin{array}{l}\text { Legislation/Other } \\
\text { Developments }\end{array}$ & $\begin{array}{c}\text { When Signed Into } \\
\text { Law }\end{array}$ & Link to Bill Text/News \\
\hline Illinois & $\begin{array}{l}\text { SB } 1704 \\
\text { Expresses state support for } \\
\text { the FutureGen project, } \\
\text { including assumption of } \\
\text { liability for injected } \mathrm{CO}_{2} \text {. }\end{array}$ & July 30, 2007 & $\begin{array}{l}\underline{\mathrm{http}: / / \text { www.ilga.gov/legis }} \\
\underline{\text { lation/fulltext.asp?DocNa }} \\
\text { me=\&SessionId=51\&GA} \\
\text { =95\&DocTypeId=SB\&D } \\
\text { ocNum=1704\&GAID=9} \\
\text { \&LegID=29844\&SpecSe } \\
\underline{\text { ss=\&Session }}\end{array}$ \\
\hline Illinois & $\begin{array}{l}\text { SB } 1987 \\
\text { Creates a clean coal } \\
\text { portfolio standard for the } \\
\text { state to otherwise encourage } \\
\text { the development of CCS- } \\
\text { equipped clean-coal projects }\end{array}$ & January 12, 2009 & $\begin{array}{l}\text { http://ilga.gov/legislation/ } \\
\text { fulltext.asp?DocName }=\& \\
\text { SessionId=51\&GA=95\& } \\
\text { DocTypeId=SB\&DocNu } \\
\text { m=1987\&GAID=9\&LegI } \\
\mathrm{D}=35238 \& \text { SpecSess }=\& \mathrm{~S} \\
\underline{\text { ession }=}\end{array}$ \\
\hline Kansas & $\begin{array}{l}\text { HB } 2419 \\
\text { Authorizes the Kansas } \\
\text { Corporation Commission to } \\
\text { issue CCS regulations }\end{array}$ & March 28, 2007 & $\begin{array}{l}\text { http://www.kslegislature. } \\
\underline{\text { org/bills/2008/2419.pdf }}\end{array}$ \\
\hline Kentucky & $\begin{array}{l}\text { HB } 1 \\
\text { Provides incentives for clean } \\
\text { energy technologies, } \\
\text { including CCS. }\end{array}$ & August 30, 2007 & $\begin{array}{l}\text { http://www.lrc.ky.gov/rec } \\
\underline{\text { ord/07s2/HB1.htm }}\end{array}$ \\
\hline Louisiana & $\begin{array}{l}\text { HB } 1220 \\
\text { Authorizes the State Mineral } \\
\text { Board to enter into } \\
\text { contracts, and assume } \\
\text { responsibility for, } \\
\text { sequestration storage } \\
\text { facilities. }\end{array}$ & July 2, 2008. & $\begin{array}{l}\underline{\text { http://www.legis.state.la. }} \\
\underline{\text { us/billdata/streamdocume }} \\
\underline{\text { nt.asp?did=483706 }}\end{array}$ \\
\hline Louisiana & $\begin{array}{l}\mathrm{HB} 1117 \\
\text { Authorizes the } \\
\text { Commissioner of } \\
\text { Conservation to regulate } \\
\mathrm{CO}_{2} \text { injections and } \\
\text { establishes procedures for } \\
\text { obtain leases for storage } \\
\text { facilities. }\end{array}$ & June 17, 2008 & $\begin{array}{l}\underline{\text { http://www.legis.state.la. }} \\
\underline{\text { us/billdata/streamdocume }} \\
\underline{\text { nt.asp?did=499939 }}\end{array}$ \\
\hline
\end{tabular}




\begin{tabular}{|c|c|c|c|}
\hline State & $\begin{array}{c}\text { Legislation/Other } \\
\text { Developments }\end{array}$ & $\begin{array}{l}\text { When Signed Into } \\
\text { Law }\end{array}$ & Link to Bill Text/News \\
\hline Oklahoma & $\begin{array}{l}\text { SB } 1765 \\
\text { Establishes a regulatory } \\
\text { regime for CCS, while } \\
\text { leaving open some issues } \\
\text { related to whether the } \\
\text { Department of } \\
\text { Environmental Quality or } \\
\text { the Corporation Commission } \\
\text { is in the lead on specific } \\
\text { aspects of CCS regulation. }\end{array}$ & June 3, 2008 & $\begin{array}{l}\text { http://webserver1.1sb.stat } \\
\text { e.ok.us/2007- } \\
\underline{\text { 08bills/HB/sb1765_hflr.rt }} \\
\underline{\mathrm{f}}\end{array}$ \\
\hline Pennsylvania & $\begin{array}{l}\text { HB } 1202 \\
\text { Authorizes the substitution } \\
\text { of CTL derived diesel for } \\
\text { the state's biodiesel } \\
\text { mandate, provided that the } \\
\text { fuel's carbon emissions are } \\
\text { offset "through carbon } \\
\text { sequestration." }\end{array}$ & July 10, 2008 & $\begin{array}{l}\text { http://www.legis.state.pa. } \\
\text { us/cfdocs/billinfo/billinfo } \\
\text { ccfm?syear=2007\&sind= } \\
\text { 0\&body=H\&type=B\&B } \\
\underline{\mathrm{N}=1202}\end{array}$ \\
\hline Pennsylvania & $\begin{array}{l}\text { SB } 266 \\
\text { Directs the Department of } \\
\text { Environmental Protection to } \\
\text { conduct a climate study, } \\
\text { which must include a } \\
\text { discussion of CCS. }\end{array}$ & July 9,2008 & $\begin{array}{l}\text { http://www.legis.state.pa. } \\
\text { us/CFDOCS/Legis/PN/P } \\
\text { ublic/btCheck.cfm?txtTy } \\
\text { pe=PDF\&sessYr=2007\& } \\
\text { sessInd=0\&billBody }=\text { S\& } \\
\text { billTyp=B\&billNbr }=026 \\
\text { 6\&pn=1554 }\end{array}$ \\
\hline Texas & $\begin{array}{l}\text { HB } 149 \\
\text { Directs the Railroad } \\
\text { Commission to be } \\
\text { responsible for the } \mathrm{CO}_{2} \text { from } \\
\text { the FutureGen program. }\end{array}$ & May 31, 2006 & $\begin{array}{l}\text { http://www.legis.state.tx. } \\
\underline{\text { us/tlodocs/793/billtext/pd }} \\
\underline{\text { fH00149F.pdf }}\end{array}$ \\
\hline
\end{tabular}




\begin{tabular}{|c|c|c|c|}
\hline State & $\begin{array}{l}\text { Legislation/Other } \\
\text { Developments }\end{array}$ & $\begin{array}{l}\text { When Signed Into } \\
\text { Law }\end{array}$ & Link to Bill Text/News \\
\hline Utah & $\begin{array}{l}\text { SB } 202 \text { Substitute } \\
\text { Directs the Division of } \\
\text { Water Quality and Division } \\
\text { of Air Quality, in } \\
\text { collaboration with the } \\
\text { Division of Oil, Gas \& } \\
\text { Mining and the Utah } \\
\text { Geological Survey, to } \\
\text { present recommended rules } \\
\text { to the Legislature's } \\
\text { Administrative Rules } \\
\text { Review Committee by } \\
\text { January 1, 2011; a progress } \\
\text { report must be made by } \\
\text { July } 1,2009 . \\
\text { The recommended rules } \\
\text { shall exclude CO } \\
\text { SB } 202 \text { separately provides } \\
\text { a } 20 \% \text { RPS; provided, } \\
\text { however, that power } \\
\text { produced from "qualifying } \\
\text { carbon sequestration } \\
\text { generation" does not count } \\
\text { against the power sales } \\
\text { baseline against which the } \\
20 \% \text { is applied. } \\
\text { "Qualifying carbon } \\
\text { sequestration generation" } \\
\text { means a fossil-fueled } \\
\text { generating facility located } \\
\text { within the geographic } \\
\text { boundary of the Western } \\
\text { Electricity Coordinating } \\
\text { Council that: (i) becomes } \\
\text { operational or retrofitted on } \\
\text { or after January } 1,2008 ; \text { and } \\
\text { (ii) reduces carbon dioxide } \\
\text { emissions through } \\
\text { permanent geological } \\
\text { sequestration or "other } \\
\text { verifiably permanent } \\
\text { reductions ... through the } \\
\text { use of technology." }\end{array}$ & March 18, 2008 & $\underline{\underline{\text { http://le.utah.gov/ } / 2008 /}}$ \\
\hline
\end{tabular}




\begin{tabular}{|c|c|c|c|}
\hline State & $\begin{array}{l}\text { Legislation/Other } \\
\text { Developments }\end{array}$ & $\begin{array}{l}\text { When Signed Into } \\
\text { Law }\end{array}$ & Link to Bill Text/News \\
\hline Washington & $\begin{array}{l}\text { The state of Washington's } \\
\text { Climate Advisory Team } \\
\text { Final Report includes } \\
\text { recommendations on CCS. }\end{array}$ & $\begin{array}{l}\text { Released } \\
\text { February 1, } 2008\end{array}$ & $\frac{\underline{\mathrm{http} / / \text { www.ecy.wa.gov/cl }}}{\frac{\text { imatechange/InterimRepo }}{\text { rt/122107 TWG_es.pdf }}}$ \\
\hline Washington & $\begin{array}{l}\text { WAC 173-218-115: Specific } \\
\text { Requirements for Class V } \\
\text { Wells Used to Inject Carbon } \\
\text { Dioxide for Permanent } \\
\text { Geologic Sequestration. } \\
\text { The state of Washington has } \\
\text { issued Class V CCS rules. }\end{array}$ & $\begin{array}{l}\text { Adopted on } \\
\text { June } 19,2008\end{array}$ & $\begin{array}{l}\frac{\text { http://apps.leg.wa.gov/W }}{\text { AC/default.aspx?cite }=17} \\
\underline{\underline{3-218-115}}\end{array}$ \\
\hline Wisconsin & $\begin{array}{l}\text { The Governor's Task Force } \\
\text { on Global Warming Final } \\
\text { Report addressed CCS. }\end{array}$ & $\begin{array}{l}\text { Released } \\
\text { July } 24,2008\end{array}$ & $\begin{array}{l}\frac{\text { http://dnr.wi.gov/environ }}{\text { mentprotect/gtfgw/docum }} \\
\text { ents/Final Report.pdf }\end{array}$ \\
\hline Wisconsin & $\begin{array}{l}\text { In } 2008 \text {, the Public Service } \\
\text { Commission opened an } \\
\text { investigation as to the } \\
\text { potential for CCS. }\end{array}$ & $\begin{array}{l}\text { Investigation has } \\
\text { closed; next steps } \\
\text { are uncertain }\end{array}$ & $\begin{array}{l}\frac{\text { http://psc.wi.gov/global }}{\text { Warming/05EI145/index- }} \\
\underline{\text { carbonSequestration.htm }}\end{array}$ \\
\hline $\begin{array}{l}\text { West } \\
\text { Virginia }\end{array}$ & $\begin{array}{l}\text { The "West Virginia Energy } \\
\text { Opportunities Plan" supports } \\
\text { CCS and calls on the } \\
\text { Department of } \\
\text { Environmental Protection to } \\
\text { issue regulations. }\end{array}$ & $\begin{array}{l}\text { Report has been } \\
\text { issued; next steps } \\
\text { are uncertain }\end{array}$ & $\begin{array}{l}\text { http://www.energywv.org } \\
\text { /community/EOD.pdf }\end{array}$ \\
\hline Wyoming & $\begin{array}{l}\text { HB } 90 \\
\text { Provides a regulatory } \\
\text { framework for CCS. }\end{array}$ & March 4, 2008 & $\begin{array}{l}\text { http://legisweb.state.wy.u } \\
\underline{\underline{\mathrm{s}} / 2008 / \text { Enroll/HB0090.pd }}\end{array}$ \\
\hline Wyoming & $\begin{array}{l}\text { HB } 89 \\
\text { Addresses pore space } \\
\text { ownership. }\end{array}$ & March 4, 2008 & $\begin{array}{l}\frac{\text { http://legisweb.state.wy.u }}{\underline{\mathrm{s} / 2008 / \text { Enroll/HB0089.pd }}} \\
\underline{\mathrm{f}}\end{array}$ \\
\hline
\end{tabular}




\section{Appendix B}

\section{Forestry}

This appendix supports the claims made in the body of the report, including a list of references cited, and consists of the following parts: (1) Idaho greenhouse emissions by sector with forestry contribution unresolved; (2) Forest carbon stock change to determine greenhouse gas emissions from Idaho's forests; (3) Annual forest change factor analysis (growth, mortality, and removals) method for determining greenhouse gas emissions from Idaho's forests; (4) Idaho greenhouse emissions by sector with forestry contribution resolved; (5) Ten recommendations for developing carbon credit markets reported in 2003 and their status in June 2009; 6) References cited.

\section{B-1. IDAHO GREENHOUSE GAS EMISSIONS BY SECTOR WITH FORESTRY CONTRIBUTION UNRESOLVED}

This section presents a modified version of the Background text in the Emissions Reduction/Offset Credits section of Carbon Issues Task Force Report. It replaces the two pie charts with Appendix Table F-1 and omits the uncertain conclusion drawn by the CCS (2008) that Idaho's forests are a net source of emissions. It replicates the presentation format of the U.S. EPA (2008) greenhouse gas inventory report, and includes the methane $\left(\mathrm{CH}_{4}\right)$ and nitrous oxide $\left(\mathrm{N}_{2} \mathrm{O}\right)$ contributions from forest wildfires separately from $\mathrm{CO}_{2}$ emissions. It also corrects fuel use sector data presented inconsistently in the CCS (2008) report, in the Executive Summary Table ES-1 and pie charts, each with different data for the fuel use sectors.

\section{B-1.1 Emissions Reductions/Offset Credits}

\section{B-1.1.1 BACKGROUND}

In early 2008 the Center for Climate Strategies finalized a greenhouse gas (GHG) Inventory Report for the state of Idaho. The purpose of this inventory was to give the state an idea of how we compare to the rest of the nation and identify our largest sources of GHG emissions. It also made projections on future emissions based on current trends. The report was developed using existing data that was available at the time of its creation. The report will be improved upon as better and more accurate data becomes available. A copy of the report can be obtained from the Idaho Department of Environmental Quality at 1410 N. Hilton in Boise, Idaho.

\section{B-1.1.1.1 Inventory Findings}

Compared nationally, Idaho is a low GHG-emitting state. Activities in Idaho accounted for approximately 35 million metric tons (MMt) of gross carbon dioxide equivalent $\left(\mathrm{CO}_{2} \mathrm{e}\right)$ emissions in 2005. This is an amount equal to about $0.5 \%$ of total U.S. gross GHG emissions (around $47^{\text {th }}$ nationally). Despite being a relatively low emitter, Idaho's gross GHG emissions increased 31\% from 1990 to 2005, while national emissions rose by only $16 \%$ over a similar period. Idaho's per capita emissions rate is also slightly higher than the national average of $25 \mathrm{MMt} \mathrm{CO}_{2} \mathrm{e} / \mathrm{yr}$ (Idaho ranged between $26-28 \mathrm{MMt}$ $\mathrm{CO}_{2} \mathrm{e} / \mathrm{yr}$ ). According to the emissions inventory (Appendix Table F-1), transportation is responsible for the largest portion of the state's emissions, followed by agriculture, residential/commercial/industrial fuel use, and electricity consumption. As Appendix Table F-1 indicates, Idaho's emissions profile varies significantly from the national profile, with discussion by sector following on the next page. 
Table B-1. Idaho and U.S.A. greenhouse gas emissions by sector, million metric tons (MMt) carbon dioxide equivalent $\left(\mathrm{CO}_{2} \mathrm{e}\right)$, with percent of total by sector, 2005 .

\begin{tabular}{|c|c|c|c|c|}
\hline \multirow[b]{2}{*}{ Sector } & \multicolumn{2}{|c|}{ Idaho } & \multicolumn{2}{|c|}{ U.S.A. } \\
\hline & $\begin{array}{c}\text { Emissions } \\
\left(\mathrm{MMt} \mathrm{CO}_{2} \mathrm{e}\right)\end{array}$ & $\begin{array}{l}\text { Percent of } \\
\text { State Total } \\
\end{array}$ & $\begin{array}{c}\text { Emissions } \\
\left(\mathrm{MMt} \mathrm{CO}_{2} \mathrm{e}\right)\end{array}$ & $\begin{array}{l}\text { Percent of } \\
\text { U.S.A. Total } \\
\end{array}$ \\
\hline Transportation & 10.2 & $29.2 \%$ & $1,912.8$ & $26.3 \%$ \\
\hline Residential/Commercial Fuel Use & 6.1 & $17.5 \%$ & 590.8 & $8.1 \%$ \\
\hline Industrial Fuel Use & (with above)* & (with above) ${ }^{*}$ & 840.1 & $11.6 \%$ \\
\hline Electricity, Consumption Based & 5.3 & $15.2 \%$ & $2,407.5$ & $33.1 \%$ \\
\hline Fossil Fuel Industry & 0.4 & $1.1 \%$ & (with above)* & (with above)* \\
\hline Subtotal: Fossil Fuel Combustion & 22.1 & $63.3 \%$ & $5,751.2$ & $79.1 \%$ \\
\hline Industrial Processes & 1.1 & $3.2 \%$ & 501.1 & $6.9 \%$ \\
\hline Waste Management & 1.4 & $4.0 \%$ & 547.7 & $7.5 \%$ \\
\hline Agriculture & 9.0 & $25.8 \%$ & 458.7 & $6.3 \%$ \\
\hline Forestry (wildfire $-\mathrm{CH}_{4} \& \mathrm{~N}_{2} \mathrm{O}$ ) & 1.3 & $3.7 \%$ & 13.1 & $0.2 \%$ \\
\hline Forestry (wildfire $-\mathrm{CO}_{2}$ ) & $\dagger$ & $\dagger$ & $\dagger$ & $\dagger$ \\
\hline Total Gross Emissions & 34.9 & $100.0 \%$ & $7,271.8$ & $100.0 \%$ \\
\hline Agricultural Soils [sink] & {$[1.2]$} & {$[3.6 \%]$} & [41.2] & {$[0.6 \%]$} \\
\hline Forestry $[\operatorname{sink}] \dagger$ & $\ddagger$ & $\ddagger$ & [784.3] & [10.8\%] \\
\hline Net Emissions [with sink offsets] & 33.7 & $96.4 \% \#$ & $6,443.3$ & $88.6 \% \#$ \\
\hline \multicolumn{5}{|c|}{$\begin{array}{l}\text { Sources: Idaho Department of Environmental Quality, based on the Idaho Green House Gas Inventory and Reference Case } \\
\text { Projections 1990-2020 preliminary draft report by the Center for Climate Strategies (CCS 2008, Table ES-1); U.S. } \\
\text { Environmental Protection Agency, Inventory of U.S. Greenhouse Gas Emissions and Sinks: 1990-2005(EPA 2009, Tables } \\
\text { ES-2, ES-3, ES-5) } \\
\text { * These indicate discrepancies between the CCS (2008) and EPA (2009) data presentations. } \\
\dagger \text { Carbon dioxide emissions from biomass burning are not included in USDA (2008) or EPA (2009) GHG inventories; } \\
\text { however } \mathrm{CH}_{4} \text { and } \mathrm{N}_{2} \mathrm{O} \text { emissions are counted so they are included here. Between 2002-2006, the annual average Idaho } \\
\text { wildfire emissions were } 89 \% \text { of all fossil fuel-burning emissions (Wiedinmyer \& Neff 2007), or } 19.7 \text { MMt } \mathrm{CO}_{2} \text { e. A row for } \\
\text { wildfire } \mathrm{CO}_{2} \text { emissions is inserted as a placeholder to indicate their existence. In the forest carbon stock change method of } \\
\text { GHG inventory, wildfire emissions are not considered explicitly, but are recognized as losses from the total carbon stock } \\
\text { change. }\end{array}$} \\
\hline \multicolumn{5}{|c|}{$\begin{array}{l}\text { \$Nationwide, annual forest growth creates a forest sink that offsets } 10.8 \% \text { of all GHG emissions. Idaho's forest status is } \\
\text { discussed in the Forestry section of this report, and Section } 4 \text { ) of this appendix. }\end{array}$} \\
\hline
\end{tabular}

Forestry emissions missing from Appendix Table B-1 are revisited in Appendix Table B-4 following data-based arguments presented in Section 3 of this appendix that Idaho's forests are a significant sink for atmospheric carbon.

\section{Transportation}

Transportation is the largest source of GHG emissions for Idaho at 29\%. This is a result of gasoline and diesel combustion. This percentage is comparable to the percent nationally that is attributed to transportation $(26 \%)$. 


\section{Agriculture}

Agriculture is Idaho's second- largest source of GHG emissions at 26\%. The primary activities that account for these emissions are enteric fermentation and manure management associated with large livestock feeding operations. Activities associated with crop residue burning and agricultural soil tillage practices also contribute significantly to this source of GHG emissions.

\section{Electricity}

Electricity Consumption accounted for $15 \%$ of the state's GHG emissions. However, the bulk of that was from imported electricity. Electricity production within the state accounted for approximately $1 \%$ of the state's emissions, and this comes from the occasional burning of natural gas. The remainder comes from electricity that is generated outside of Idaho but imported for consumption. Idaho imports electricity that is generated using coal and natural gas combustion. Idaho has no utility coal-fired power generation in-state. Nationally, electricity production is the largest source of GHG emissions (32\%). Idaho (15\%) is much lower because of the state's hydroelectricity generating capacity.

In the electricity sector, industrial use is $40 \%$, residential $35 \%$ and commercial $25 \%$. Residential and commercial use is often lumped together as buildings, since the bulk of the electricity used is for space conditioning, lighting and other uses associated with buildings. Thus Idaho's buildings sector uses $61 \%$ of Idaho's electricity (13,215 GWh or 3.2 MMt).

\section{Fuel Use}

Fuel Use in Idaho accounted for about 18\%, compared to 20\% nationally. Most of this comes from the burning of coal, natural gas, and oil for heating purposes. The remainder is from cement, lime, and semi-conductor manufacturing and industrial processes that emit fluorinated gases.

\section{Buildings}

Buildings are one of Idaho's fastest growing areas, and will account for increasing energy use and emissions. As discussed above, residential and commercial buildings use $61 \%$ of Idaho's electricity, accounting for 3.2 MMt of emissions. In addition residential buildings create 7\% of Idaho's fossil fuel emissions and commercial buildings create $4 \%$ for a total fossil fuel contribution of 1.6 MMt (Sightline Institute). The combined total of electric and fossil fuel emissions for Idaho's buildings sector is 4.8 MMt or 13\% of Idaho's emissions total. 


\section{B-2. FOREST CARBON STOCK CHANGE METHOD FOR DETERMINING GREENHOUSE GAS EMISSIONS FROM IDAHO'S FORESTS}

This method of GHG emissions determination uses the widely accepted forest stock change method (IPCC 2003), but this is a fledgling art (Schoene 2002). The method relies on two estimates of forest growing stock volume at different periods of time. If forest growing stock is greater in the more recent period, the forest has functioned as a net sink for atmospheric carbon during the time between measurements. Conversely, if forest growing stock has decreased over time, then the forest has functioned as a net source of carbon emissions. The reliability of this method depends strongly upon a reasonably consistent sequence of inventories (Smith eta al. 2007). Therein is the problem.

Given a data set, the determination becomes a straightforward addition/subtraction problem of growing stock volume change. Carbon stocks in unmeasured on-site forest pools are directly related to and estimable from the wood volume on forest lands (Sampson 2002, Woodbury et al. 2007). Each on-site carbon pool (boles of trees, branches, and roots) can be determined using representative multipliers of the growing stock, which is the wood volume in trees with diameters greater than or equal to 5 inches diameter at breast height (i.e., 4.5 feet from the ground at the base of the tree). Under the stock change method the proportion of growing stock to total forest carbon stocks varies little from year to year. For example, the growing stock carbon pool varied from $34.4 \%$ to $35.9 \%$ of the total forest carbon stocks in the 1990-2008 annual modeled measurements published in the EPA's GHG inventory for Idaho (EPA 2009).

The existence of four potential data sets for Idaho derived from forest
Appendix Sidebar F-1. The U.S. Forest Service Forest Inventory and Analysis (FIA) Project

The U.S. Forest Service has been conducting periodic and systematic inventories of timber resources on all U.S. forests since 1952 under an umbrella research project called Forest Inventory and Analysis (FIA). The FIA data provide the basis for the ten-year resource assessment required by the Forest and Rangeland Renewable Resources Planning Act of 1974 (RPA). Recent FIA reports are available online at http://fia.fs.fed.us/.

The FIA project recently switched from a periodic inventory to a continuous annual forest inventory, and is currently in a transition phase that will take several more years to complete. One-tenth of the permanent inventory plots will be measured each year, therefore it will take 10 years to complete the first inventory cycle. Early inventory reports warn about the comparability of data from one period to the next because of changing definitions of timberland and data collection methods. Nevertheless FIA data remain the only source of data for establishing trends in timber inventory and the factors that cause changes: growth, mortality, and removals. The change in timber growing stock from one period to the next provides the quantitative basis for estimating the change in forest carbon stock, or carbon flux.

Forest inventory data have traditionally been provided only for timberlands, defined as forest land "that is producing or is capable of producing crops of industrial wood and not withdrawn from timber utilization by statute or administrative regulation." The 3.975 million acres of Idaho's national forests in the National Wilderness Preservation System have not traditionally been included in forest inventory data. A new U.S. Forest Service Internet-based service called Forest Inventory Data Online (FIDO) now provides forest growing stock estimates for "reserved" as well as "unreserved" forest lands; the former category is primarily wilderness areas, the latter, timberlands as defined above.

For the purpose of greenhouse gas emissions inventory reports the best data available currently for estimating carbon flux from 1990 to 2005 and later are either the 2007 RPA forest resource assessment data or the data generated by FIDO. Either set is preferable to the "fill-in" data (Smith et al. 2007) that were used as the 1990 baseline in the USDA (2008) and EPA (2009) greenhouse gas inventory reports. These "fill-in" baseline data lead to the conclusion that Idaho's forests are a source of carbon emissions.

The FIDO data were selected as most appropriate for this analysis because they provide data on reserved forest lands that were not previously available. In addition, the volume of sound dead timber is determined by field measurements rather than calculated formulaically as a function of growing stock volume. 
inventory data complicates the problem. These data for the most part are collected and published by the USFS Forest Inventory and Analysis (FIA) research project (see Appendix Sidebar B-1). The data used by the USDA (2008) and EPA (2009) in their national greenhouse gas inventory reports, and for the Carbon Calculation Tool (Smith et al. 2007) is the worst possible choice because it overstates the 1990 forest carbon stock baseline. This can be confirmed by analysis of the four data sets presented in Appendix Table B-2.

The forest inventory data for 1990 in data sets I and III are based on estimates by individual national forests in Idaho instead of field measurements supervised by researchers. At the time that option was available, and judging from these data comparisons Idaho's timber inventory in 1990 was overstated at 39 billion cubic feet instead of 34 or 35 billion cubic feet that were published in national forest inventory reports.

Another problem evident from these data are the change in standing dead timber that were measured in the forests but not reflected in the greenhouse gas inventory, which apparently is determined as a fixed proportion of live growing stock. If the increase in dead timber between 1997 and 2007 of either 2.6 billion cubic feet (data set II) or 3.0 billion cubic feet (data sets III or IV) were added to the growing stock inventory, then using a 39 billion cubic feet inventory for 1990 there would be more carbon stored in the forest in 2007 than in 1990 (see data set III).

Table B-2. Four data sets with potential for determining forest carbon stock change from 1990 to 2005 for greenhouse gas inventory purposes (data source in each table cell).

\begin{tabular}{|c|c|c|c|c|c|c|c|c|}
\hline \multirow[b]{2}{*}{$\begin{array}{l}\text { Dat } \\
\text { Set }\end{array}$} & \multirow[b]{2}{*}{ Year } & \multicolumn{4}{|c|}{$\begin{array}{l}\text { Timber Inventory by Class of Timber } \\
\text { (billion cubic feet) }\end{array}$} & \multicolumn{3}{|c|}{$\begin{array}{l}\text { Annual Change Factors } \\
\text { (billion cubic feet) }\end{array}$} \\
\hline & & $\begin{array}{l}\text { Growing } \\
\text { Stock }\end{array}$ & Live Cull & $\begin{array}{c}\text { Sound } \\
\text { Dead }\end{array}$ & $\begin{array}{c}\text { All } \\
\text { Timber }\end{array}$ & $\begin{array}{l}\text { Gross } \\
\text { Growth }\end{array}$ & Mortality & Removals \\
\hline \multirow{2}{*}{ I } & 2005 & 37.161 & Not reported & $*$ & Not reported & Not reported & Not reported & Not reported \\
\hline & 1990 & 39.200 & Not reported & $*$ & Not reported & Not reported & Not reported & Not reported \\
\hline \multirow{2}{*}{$\mathrm{II}^{\dagger}$} & 2007 & 39.917 & Not reported & 6.012 & 45.929 & 1.046 & 0.474 & Not reported \\
\hline & 1991 & 35.557 & Not reported & 3.384 & 38. & Not reported & Not reported & Not reported \\
\hline \multirow{2}{*}{ III } & 2007 & $37.161[\mathrm{a}]$ & $0.237[\mathrm{a}]$ & $5.044[\mathrm{a}]$ & $42.443[\mathrm{a}]$ & $0.994[\mathrm{a}]$ & 0.383 [a] & $0.246[\mathrm{a}]$ \\
\hline & 1991 & $39.560[\mathrm{~b}]$ & $0.671[\mathrm{~b}]$ & $2.096[\mathrm{~b}]$ & $42.327[\mathrm{~b}]$ & $1.106[\mathrm{~b}]$ & $0.290[\mathrm{~b}]$ & $0.309[\mathrm{~b}]$ \\
\hline \multirow{6}{*}{ IV } & 2007 & $37.161[\mathrm{a}]$ & $0.237[\mathrm{a}]$ & $5.044[\mathrm{a}]$ & $42.443[\mathrm{a}]$ & $0.994[\mathrm{a}]$ & $0.383[\mathrm{a}]$ & $0.246[\mathrm{a}]$ \\
\hline & 2002 & $40.050[\mathrm{a}]$ & $0.657[\mathrm{c}]$ & $3.363[\mathrm{c}]$ & $44.070[\mathrm{c}]$ & $1.066[\mathrm{c}]$ & $0.431[\mathrm{c}]$ & $0.253[\mathrm{c}]$ \\
\hline & 1997 & $39.257[\mathrm{a}]$ & $0.677[\mathrm{~d}]$ & $2.092[\mathrm{~d}]$ & $42.025[\mathrm{~d}]$ & $1.095[\mathrm{~d}]$ & $0.228[\mathrm{~d}]$ & $0.252[\mathrm{~d}]$ \\
\hline & 1987 & $32.591[\mathrm{a}]$ & $0.982[\mathrm{e}]$ & $1.937[\mathrm{e}]$ & $35.509[\mathrm{e}]$ & $0.887[\mathrm{f}]$ & $0.161[\mathrm{f}]$ & $0.336[\mathrm{f}]$ \\
\hline & 1977 & $31.885[\mathrm{a}]$ & $0.882[\mathrm{~g}]$ & $1.960[\mathrm{~g}]$ & $34.726[\mathrm{~g}]$ & $0.799[\mathrm{~g}]$ & $0.123[\mathrm{~g}]$ & $0.395[\mathrm{~g}]$ \\
\hline & 1953 & $28.890[\mathrm{a}]$ & not reported & $3.662[\mathrm{~h}]$ & $32.552[\mathrm{~h}]$ & $0.690[\mathrm{~h}]$ & $0.208[\mathrm{~h}]$ & $0.265[\mathrm{~h}]$ \\
\hline \multicolumn{9}{|c|}{$\begin{array}{l}\text { I. Data generated by Stephen M. Roe, E.H. Pechan \& Associates, Inc., Celebration, FL, for Center for Climate Strategies } \\
\text { (CCS) Idaho Greenhouse Gas Inventory and Reference Case Projections 1990-2020 report prepared for the Idaho } \\
\text { Department of Environmental Quality, May 2008, using the U.S. Forest Carbon Calculation Tool [CCT]: Forest-Land } \\
\text { Carbon Stocks and Net Annual Stock Change (Smith et al. 2007). This data set and method are also used in the USDA } \\
\text { (2008) and EPA (2009) national greenhouse gas inventory reports. }\end{array}$} \\
\hline \multicolumn{9}{|c|}{$\begin{array}{l}\text { I* Sound dead - The Carbon Calculation Tool (CCT) output generated by CCS identified } 79.6 \text { teragrams (Tg) of carbon in } \\
\text { the "standing dead" carbon pool in } 1990 \text { and } 80.1 \mathrm{Tg} \text { in } 2005 \text {, an increase of } 0.5 \mathrm{Tg} \text { or, using a conversion factor of } \\
30 \text { pounds of wood per cubic foot, approximately } 0.037 \text { billion cubic feet of dead wood. In comparison with the other data } \\
\text { sets, this one missed the substantial increase in dead wood in Idaho's forests (between } 2.6 \text { and } 3.0 \text { billion cu. ft.), which is } \\
\text { a large enough change to move Idaho's forests from the "source" category (as a result of the } 2.0 \text { billion cu. ft. growing }\end{array}$} \\
\hline
\end{tabular}


stock decrease from 1990 to 2005) to the "sink" category (for live and dead trees, volume gain in the range of 0.6 to 1.0 billion cu. $\mathrm{ft}$.).

II. Data downloaded from USDA Forest Service (2009). "Forest Inventory Data Online (FIDO II version)." http://fiatools.fs.fed.us/fido/index.html (accessed 26 June 2009). Data tables are only available for 1991 and 2007, which is convenient for greenhouse gas inventory purposes.

$\mathrm{II}^{\dagger} \underline{\text { Wilderness areas }}$ - In addition to unreserved forest lands (i.e., timberlands), FIDO II provides estimates of volume in trees $>5$-inch diameter on reserved forest lands (see table below). The 3.975 million acres of National Forest System lands in the National Wilderness Preservation System include 3.2 million acres of forest wilderness that heretofore have not been included in forest inventory data and therefore have not been included in greenhouse gas emissions inventories.

Wood volume on reserved forest land in Idaho, 1991and 2007 (billion cubic feet)

\begin{tabular}{cccc}
\hline Year & Live trees & Dead trees & Total \\
\hline 2007 & 6.232 & 2.114 & 8.346 \\
1991 & 6.567 & 1.097 & 7.664 \\
\hline
\end{tabular}

III. The two sources of data are [a] for 2007, the most current RPA data published to meet the mandate given to the USFS (USDA-FS) by the Forest and Rangeland Renew-able Resources Planning Act of 1974 (RPA); and [b] for 1991, the last complete periodic forest inventory for the State of Idaho was conducted in 1991. Citations are as follows:

[a] Smith et al. 2009. Forest Resources of the United States, 2007. USDA-FS GTR-W0-78. This report is in press; data for the "2007 RPA Resource Tables" used here are available online at http://fia.fs.fed.us/programfeatures/rpa/default.asp (accessed 17 April 2009).

[b] Brown, M.J. \& Chojnacky, D.C. 1996. Idaho's Forests, 1991. USDA-FS INT-RB-88.

IV. This is the complete set of published RPA forest inventories:

[a] Smith et al. 2009. Forest Resources of the United States, 2007. USDA-FS GTR-W0-78. This report is in press; data for the "2007 RPA Resource Tables" used here are available online at http://fia.fs.fed.us/programfeatures/rpa/default.asp (accessed 17 April 2009).

[c] Smith et al. 2004. Forest Resources of the United States, 2002. USDA-FS GTR-NC-241.

[d] Smith et al. 1999. Forest Resources of the United States, 1997. USDA-FS GTR-NC-219.

[e] Waddell et al. 1989. Forest Statistics of the United States, 1987. USDA-FS PNW-RB-168.

[f] Waddell. 1992. Forest Statistics of the Western States, 1987. USDA-FS PNW Research Station unnumbered report for the Western States Legislative Forestry Task Force.

[g] USDA Forest Service. 1982. An Analysis of the Timber Situation in the United States, 1952-2030. USDA-FS Forest Resource Report 23.

[h] USDA Forest Service. 1958. Timber Resources for America's Future. USDA-FS Forest Resource Report 14. Note: for growing stock time series data in later inventory reports, Forest Service analysts increased growing stock reported in 1958 by $36 \%$ to the 28.890 billion cubic feet on this table; the same increase was used to adjust the "sound dead" and "annual change factors" data in this table. 


\section{B-3. ANNUAL FOREST CHANGE FACTOR ANALYSIS (GROWTH, MORTALITY, AND REMOVALS) METHOD FOR DETERMINING GREENHOUSE GAS EMISSIONS FROM IDAHO'S FORESTS}

The method of forest GHG emissions determination illustrated in Appendix Table B-3 is an original contribution for this report. Discussion of findings and methods follow on the next page.

Table B-3. Carbon flux in Idaho's forests, 2005 and 2006 (Million metric tons $\mathrm{CO}_{2}$ equivalent or MMt $\left.\mathrm{CO}_{2} \mathrm{e}\right)$.

\begin{tabular}{|c|c|c|}
\hline & $\mathrm{MMt} \mathrm{CO}_{2} \mathrm{e}^{*}$ & Source \\
\hline Annual gross growth, unreserved forest lands (timberland) $\dagger$ & $-\quad 54.3$ & FIDO \\
\hline Annual gross growth, reserved forest lands (wilderness) $\dagger$ & 6.6 & FIDO \\
\hline Annual removals (timberland) $\dagger$ & 15.9 & FIA TPO \\
\hline Annual removals converted to wood products, 2005 & 3.7 & $\mathrm{CCS}$ \\
\hline $\mathrm{CO}_{2}$ emissions, sound dead timber (timberland only) $\dagger$ & 5.2 & FIA RPA \\
\hline $\mathrm{CO}_{2}$ emissions, sound dead timber (wilderness) & 1.2 & estimated \\
\hline $\mathrm{CO}_{2}$ emissions, slash burning (timberland only) $\ddagger$ & 3.1 & FIA TPO \\
\hline $\mathrm{CO}_{2}$ emissions, wildfires (2002-2005 average) & $+\quad 18.4$ & NCAR \\
\hline $\mathrm{CH}_{4}$ and $\mathrm{N}_{2} \mathrm{O}$ emissions, 2005 wildfires & 1.3 & $\mathrm{CCS}$ \\
\hline Total carbon flux, 2005 & $-\quad 19.5$ & $\Sigma$ of above \\
\hline Additional emissions, 2006 wildfires & 14.7 & NCAR \\
\hline Additional $\mathrm{CH}_{4}$ and $\mathrm{N}_{2} \mathrm{O}$ emissions, 2006 wildfires & 1.0 & estimated \\
\hline Total carbon flux, 2006 & $-\quad 3.8$ & $\Sigma$ of above \\
\hline \multicolumn{3}{|c|}{ 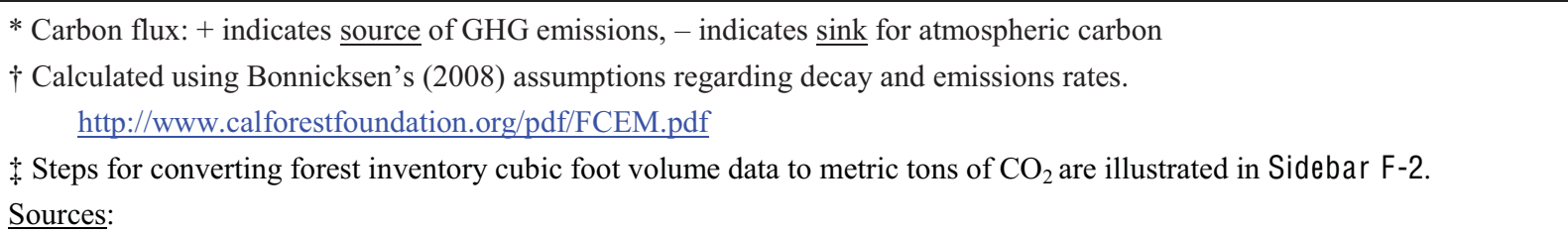 } \\
\hline \multicolumn{3}{|c|}{ 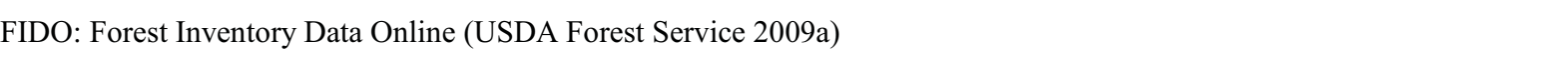 } \\
\hline \multicolumn{3}{|c|}{$\begin{array}{l}\text { FIA TPO: Forest Inventory and Analysis, Timber Products Output (USDA Forest Service 2009b) } \\
\text { http://ncrs2.fs.fed.us/4801/fiadb/rpa tpo/wc rpa tpo.ASP }\end{array}$} \\
\hline \multicolumn{3}{|c|}{ FIA RPA: Forest Inventory and Analysis, Resources Planning Act report data (Smith et al. 2009) } \\
\hline \multicolumn{2}{|c|}{ CCS: Center for Climate Solutions (CCS 2008) } & http://www.deq.idaho.gov/air/prog issues/climate change/pdfs/ghg inventory idaho sp08.pdf \\
\hline $\begin{array}{l}\text { NCAR: National Center for Atmospheric Research (Wiedinmyer \& Neff } 2 \\
\text { http://www.cbmjournal.com/content/2/1/10 }\end{array}$ & & \\
\hline
\end{tabular}

This analysis of factors that change the stock of carbon in forest pools is more accurate than the stock change method because it uses measured change data change for many variables, not just change in growing stock volume to which formulae are applied for other carbon pools. The data in Appendix Table B-3 are compiled from a variety of sources. Many of these are new data not previously available, such as growing stock in wilderness areas not counted under the stock change method and wildfire 
emissions that are also not explicitly included in the stock change method. The magnitude of wildfire emissions causes one to wonder why wildfires are not included in greenhouse gas inventories. Carbon dioxide is carbon dioxide, a greenhouse gas whether it comes from burning coal or biomass.

\section{B-3.1 Findings}

Wildfires were the single largest source of emissions in the state, with 19.7 in 2005 and $35.4 \mathrm{MMt}$ $\mathrm{CO}_{2} \mathrm{e}$ in 2006. Because annual tree growth was more than this, Idaho's forests functioned as a net carbon sink for 19.5 $\mathrm{MMt} \mathrm{CO}_{2} \mathrm{e}$ in 2005 and 3.8 $\mathrm{MMt} \mathrm{CO}_{2} \mathrm{e}$ in 2006 (Appendix Table B-3). In 2005, all sources of fossil fuel combustion in the state emitted 22.1 $\mathrm{MMt} \mathrm{CO}_{2} \mathrm{e}$, with the transportation sector accounting for almost half of that (Appendix Table B-1). Taking these findings together, the 2005 forest carbon sink in Idaho effectively offset $88 \%$ of the emissions from fossil fuel burning in the state and $17 \%$ in 2006 .

\section{B-3.2 Methods Discussion}

The growing stock volume data is converted to carbon with one conversion factor that accounts for the other on-site carbon pools (see Appendix Sidebar B-2). Wildfire emissions data were developed by the National Center for Atmospheric Research (NCAR, see Wiedinmyer \& Neff 2007). The analysis also uses data developed by the Center for Climate Strategies, the consulting firm that provided the preliminary greenhouse gas inventory (CCS 2008) for the Idaho Dept. of Environmental Quality. CCS analysts relied on the USFS's Carbon Calculation Tool (Smith et al. 2007).

This analysis is based on a more complete set of data than is used under the widely accepted forest stock change method and is therefore more accurate. It relies primarily on the forest growing stock volume inventory data collected by the Forest Inventory and Analysis (FIA) research unit of the USFS (see Appendix Sidebar F-1). The data are published every ten years to meet the requirements of the Forest and Rangeland Renewable Resources Planning Act of 1974 (RPA). These data are also available from the Forest Inventory Data Online (FIDO) Internet site maintained by the USFS.
Appendix Sidebar B-1. Converting forest growing stock (GS) volume inventory data (cubic feet or $\mathrm{ft}^{3}$ ) to a carbon stock mass estimate $\left(\mathrm{M} \mathrm{MtC}_{2} \mathrm{e}\right)$

Several steps are involved in converting the forest growing stock (GS) volume data collected and published by the U.S. Forest Service Forest Inventory and Analysis (FIA) project into carbon (C) stock, a weight measure, and then the carbon dioxide equivalent $\left(\mathrm{CO}_{2} \mathrm{e}\right)$. The usual reported measure of GS volume is million cubic feet $\left(\mathrm{Mft}^{3}\right)$. The conversion factor at the end of the steps below can be applied to a volume measure of timber growing stock $\left(\mathrm{M} \mathrm{ft}^{3}, \mathrm{mft}^{3}\right.$, or $\left.\mathrm{ft}^{3}\right)$ to obtain the $\mathrm{CO}_{2} \mathrm{e}$ value in metric tons (Mt).

$1,000,000$ cubic feet $\left(\mathrm{Mft}^{3}\right)$ of timber growing stock (GS)

$\times 31$ pounds of carbon $(\mathrm{C})$ in all on-site forest carbon pools (see Sampson 2002;

half of the on-site carbon stock is above-ground and half below)

$31,000,000$ pounds of $\mathrm{C}$ per Mft3 GS

$\div 2,205$ pounds per metric ton (Mt)

$14,605 \mathrm{Mt} \mathrm{C}$ per Mft3 GS

$\times 3.67$ units of $\mathrm{CO} 2$ per unit of $\mathrm{C}^{*}$

51,169 Mt CO2e per Mft3 GS

$\div 1,000$ units

51.169 Mt CO2e per Kft3 GS

$\div 1,000$ units

$0.051619 \mathrm{Mt} \mathrm{CO}_{2}$ e per $\mathrm{ft}^{3} \mathrm{GS}$ 


\section{B-4. IDAHO GREENHOUSE EMISSIONS BY SECTOR WITH FORESTRY CONTRIBUTION RESOLVED}

This section presents a modified version of the Background text in the Emissions Reduction/Offset Credits section of Carbon Issues Task Force Report. It replaces the two pie charts with Appendix Table B-4 on the following page. It replaces the conclusion drawn by the CCS (2008) that Idaho's forests are a net source of emissions with conclusions drawn from the annual forest factor change analysis in the preceding section.

\section{B-4.1 Emissions Reductions/Offset Credits}

\section{B-4.1.1 BACKGROUND}

In early 2008 the Center for Climate Strategies finalized a greenhouse gas (GHG) Inventory Report for the state of Idaho. The purpose of this inventory was to give the state an idea of how we compare to the rest of the nation and identify our largest sources of GHG emissions. It also made projections on future emissions based on current trends. The report was developed using existing data that was available at the time of its creation. The report will be improved upon as better and more accurate data becomes available. A copy of the report can be obtained from the Idaho Department of Environmental Quality at 1410 N. Hilton in Boise, Idaho.

\section{B-4.1.1.1 Inventory Findings}

Compared nationally, Idaho is a low GHG-emitting state. Activities in Idaho accounted for approximately 35 million metric tons (MMt) of gross carbon dioxide equivalent $\left(\mathrm{CO}_{2} \mathrm{e}\right)$ emissions in 2005. This is an amount equal to about $0.5 \%$ of total U.S. gross GHG emissions (around $47^{\text {th }}$ nationally). Despite being a relatively low emitter, Idaho's gross GHG emissions increased 31\% from 1990 to 2005, while national emissions rose by only $16 \%$ over a similar period. Idaho's per capita emissions rate is also slightly higher than the national average of $25 \mathrm{MMt} \mathrm{CO}_{2} \mathrm{e} / \mathrm{yr}$ (Idaho ranged between $26-28 \mathrm{MMt}$ $\mathrm{CO}_{2} \mathrm{e} / \mathrm{yr}$ ). According to the emissions inventory, transportation is responsible for the largest portion of the state's emissions, followed by agriculture, residential/commercial/industrial fuel use, and electricity consumption (Appendix Table B-4). As the table indicates, Idaho's emissions profile varies significantly from the national figures in a couple of areas, with discussion following the table.

Forests can both prevent and reduce greenhouse gas (GHG) emissions while simultaneously providing essential environmental and social benefits, including clean water, wildlife habitat, recreation, forest products, and other values and uses (SAF 2008). However, wildfire emissions in Idaho represent the largest single source of GHG emissions. According to the USFS, northern Idaho's forests are among the most productive in the nation (Wilson and Van Hooser 1993), and tree growth in Idaho is substantially greater than wildfire emissions and resultant tree mortality. Including all factors, including emissions from dead trees, Idaho's forest in 2005 sequestered new carbon stocks using $\mathrm{CO}_{2}$ acquired from the atmosphere to effectively offset $88 \%$ of all fossil fuel-burning emissions in the state, or almost $60 \%$ of all GHG emissions in the state (Appendix Table B-4). 
Table B-4. Idaho and U.S.A. greenhouse gas emissions by sector, million metric tons (MMt) carbon dioxide equivalent $\left(\mathrm{CO}_{2} \mathrm{e}\right)$, with percent of total by sector, 2005 .

\begin{tabular}{|c|c|c|c|c|}
\hline \multirow[b]{2}{*}{ Sector } & \multicolumn{2}{|c|}{ Idaho } & \multicolumn{2}{|c|}{ U.S.A. } \\
\hline & $\begin{array}{c}\text { Emissions } \\
\left(\mathrm{MMt} \mathrm{CO}_{2} \mathrm{e}\right)\end{array}$ & $\begin{array}{l}\text { Percent of } \\
\text { State Total }\end{array}$ & $\begin{array}{c}\text { Emissions } \\
\left(\mathrm{MMt} \mathrm{CO}_{2} \mathrm{e}\right)\end{array}$ & $\begin{array}{c}\text { Percent of } \\
\text { U.S.A. Total }\end{array}$ \\
\hline Transportation & 10.2 & $29.2 \%$ & $1,912.8$ & $26.3 \%$ \\
\hline Residential/Commercial Fuel Use & 6.1 & $17.5 \%$ & 590.8 & $8.1 \%$ \\
\hline Industrial Fuel Use & (with above)* & (with above)* & 840.1 & $11.6 \%$ \\
\hline Electricity, Consumption Based & 5.3 & $15.2 \%$ & $2,407.5$ & $33.1 \%$ \\
\hline Fossil Fuel Industry & 0.4 & $1.1 \%$ & (with above)* & (with above)* \\
\hline Subtotal: Fossil Fuel Combustion & 22.1 & $63.3 \%$ & $5,751.2$ & $79.1 \%$ \\
\hline Industrial Processes & 1.1 & $3.2 \%$ & 501.1 & $6.9 \%$ \\
\hline Waste Management & 1.4 & $4.0 \%$ & 547.7 & $7.5 \%$ \\
\hline Agriculture & 9.0 & $25.8 \%$ & 458.7 & $6.3 \%$ \\
\hline Forestry (wildfire $-\mathrm{CH}_{4} \& \mathrm{~N}_{2} \mathrm{O}$ ) & 1.3 & $3.7 \%$ & 13.1 & $0.2 \%$ \\
\hline Forestry (wildfire $\left.-\mathrm{CO}_{2}\right) \dagger$ & $\{18.4\}$ & $\dagger$ & $\{293.0\}$ & $\dagger$ \\
\hline Total Gross Emissions & 34.9 & $100.0 \%$ & $7,271.8$ & $100.0 \%$ \\
\hline Agricultural Soils [sink] & {$[1.2]$} & {$[3.4 \%]$} & [41.2] & {$[0.6 \%]$} \\
\hline Forestry $[\operatorname{sink}] \ddagger$ & {$[20.8]$} & {$[59.6 \%]$} & {$[784.3]$} & [10.8\%] \\
\hline Net Emissions [with sink offsets] & 12.9 & $37.0 \% \#$ & $6,443.3$ & $88.6 \% \#$ \\
\hline \multicolumn{5}{|c|}{$\begin{array}{l}\text { Sources: Idaho Department of Environmental Quality, based on the Idaho Green House Gas Inventory and Reference Case } \\
\text { Projections 1990-2020 preliminary draft report by the Center for Climate Strategies (CCS 2008, Table ES-1); U.S. } \\
\text { Environmental Protection Agency, Inventory of U.S. Greenhouse Gas Emissions and Sinks: 1990-2005 (EPA 2008, Tables } \\
\text { ES-2, ES-3, ES-5) } \\
\text { * These indicate discrepancies between the CCS (2008) and EPA (2008) data presentations. } \\
\text { † Carbon dioxide emissions from biomass burning are not included in USDA (2008) or EPA (2009) GHG inventories; } \\
\text { however CH4 and N2O emissions are counted so they are included here. Between 2002-2006, the annual average Idaho } \\
\text { wildfire emissions were } 89 \% \text { of all fossil fuel-burning emissions (Wiedinmyer \& Neff 2007), or } 19.7 \mathrm{MMt} \mathrm{CO}_{2} \text { e. A row for } \\
\text { wildfire } \mathrm{CO}_{2} \text { emissions is inserted as a placeholder to indicate their existence. In the forest carbon stock change method of } \\
\text { GHG inventory, wildfire emissions are not considered explicitly, but are recognized as losses from the total carbon stock } \\
\text { change. } \\
\text { \# The net total includes an adjustment for the CH4 \& N2O emissions above. } \\
\text { \# Net emissions as percent of gross emissions, after deducting sink offset effects. The forestry sink offset is equal to } 88 \% \text { of } \\
\text { the fossil fuel-burning emissions. }\end{array}$} \\
\hline
\end{tabular}

\section{Transportation}

Transportation is the largest source of GHG emissions for Idaho at $29 \%$. This is a result of gasoline and diesel combustion. This percentage is comparable to the percent nationally that is attributed to transportation $(26 \%)$.

\section{Agriculture}

Agriculture is Idaho's second- largest source of GHG emissions at 26\%. The primary activities that account for these emissions are enteric fermentation and manure management associated with large 
livestock feeding operations. Activities associated with crop residue burning and agricultural soil tillage practices also contribute significantly to this source of GHG emissions.

\section{Electricity}

Electricity Consumption accounted for $15 \%$ of the state's GHG emissions. However, the bulk of that was from imported electricity. Electricity production within the state accounted for approximately $1 \%$ of the state's emissions, and this comes from the occasional burning of natural gas. The remainder comes from electricity that is generated outside of Idaho but imported for consumption. Idaho imports electricity that is generated using coal and natural gas combustion. Idaho has no utility coal-fired power generation in-state. Nationally, electricity production is the largest source of GHG emissions (32\%). Idaho (15\%) is much lower because of the state's hydroelectricity generating capacity.

In the electricity sector, industrial use is $40 \%$, residential $35 \%$ and commercial $25 \%$. Residential and commercial use is often lumped together as buildings, since the bulk of the electricity used is for space conditioning, lighting and other uses associated with buildings. Thus Idaho's buildings sector uses $61 \%$ of Idaho's electricity (13,215 GWh or 3.2 MMt).

\section{Fuel Use}

Fuel Use in Idaho accounted for about 18\%, compared to 20\% nationally. Most of this comes from the burning of coal, natural gas, and oil for heating purposes. The remainder is from cement, lime, and semi-conductor manufacturing and industrial processes that emit fluorinated gases.

\section{Buildings}

Buildings are one of Idaho's fastest growing areas, and will account for increasing energy use and emissions. As discussed above, residential and commercial buildings use $61 \%$ of Idaho's electricity, accounting for 3.2 MMt of emissions. In addition residential buildings create 7\% of Idaho's fossil fuel emissions and commercial buildings create $4 \%$ for a total fossil fuel contribution of 1.6 MMt (Sightline Institute). The combined total of electric and fossil fuel emissions for Idaho's buildings sector is 4.8 MMt or 13\% of Idaho's emissions total. 


\section{B-5. TEN RECOMMENDATIONS FOR DEVELOPING CARBON CREDIT MARKETS REPORTED IN 2003 AND THEIR STATUS IN JUNE 2009}

In 2003 the forestry subcommittee of the Idaho Carbon Sequestration Advisory Committee (Kummet et al. 2003) recommended that the state of Idaho continue to explore the opportunities afforded by developing carbon credit markets and adopt a facilitation posture toward the state, tribal and private production and sale of carbon credits, and further recommended the following ten points for immediate consideration. These are listed below, and each recommendation is followed in an italicized parenthetical statement regarding the status of these recommendations as of June 2009.

1. Expand the Idaho Carbon Sequestration Advisory Committee's exploratory research into a more detailed evaluation of what other States have accomplished and use their mistakes and successes as a guideline to develop Idaho forest carbon policy. (Not undertaken.)

2. Charge a state agency (such as Idaho Dept. of Agriculture) to provide standards and guidelines for defining, measuring, estimating and monitoring carbon production that are compatible with national and international systems. (Not undertaken.)

The impending emergence of a national system perhaps precludes the need to do this.

3. Fund the calibration of an existing baseline model to quantify the baseline levels of forest carbon sequestration. (Not undertaken.)

4. Contract research to actually measure the carbon response of Idaho forest types to various silvicultural practices and create carbon projection protocols that could easily be followed by foresters. (Not undertaken.)

Current regional protocols developed by the USFS understate the carbon sequestration ability of these forests, averaging them with low-productivity dry-site forests on the continental divide to develop a regional average used in carbon models (O'Laughlin 2008). This effectively cheats owners of the most productive forests and rewards those whose lands are generally not actively managed due to low productivity. In addition, best management practices can help foresters become accustomed to providing new ecosystem services, including carbon sequestration.

5. The state should provide or fund adequate extension training to Idaho foresters and forest owners to enhance awareness on carbon sequestration opportunities, methods, and marketing potential (i.e., how to sequester carbon). (An effort to provide information on the Internet was undertaken in 2008, see URLs below.)

a. Idaho OnePlan: "Carbon Sequestration" http://www.oneplan.org/CarbonSequestration.shtml

b. Woodland Notes (University of Idaho Extension): "Forests and Carbon" (O'Laughlin and Mahoney 2008a) and "Payments for Forest Carbon Sequestration" (O'Laughlin and Mahoney 2008b) (URLs in References cited section).

6. The state should maintain an updated and easily accessible list of carbon credit opportunities (perhaps a web site) and provide marketing information and assistance to citizens interested in selling carbon credits. (Not undertaken.)

7. Develop guidelines and training for setting up carbon projects and calculating the carbon credits on specific sites. These should be very similar to other States and countries, realizing that items may change as the carbon sequestration programs and the science surrounding them evolve. (Not undertaken.) 
8. The state should provide a legal standard contract format and process for carbon credit sales. (Not undertaken.)

The Chicago Climate Exchange offers this service (see CCX 2009).

9. Pass the necessary enabling legislation to authorize the Idaho Department of Lands to design carbon projects and implement carbon credit sales to enhance the state educational endowment fund when credits become a viable and tradable commodity. (Not undertaken.)

10. Provide one (1) entity or agency to register all carbon projects and credits within the state and group these projects by type (e.g., reforestation, afforestation, no-till agriculture, etc.). Project registry should be sensitive to special consideration projects such as: tribal jurisdictional issues, industry with ownership in more than one state etc. (Not undertaken.)

The ICSAC Forestry Subcommittee feels this effort is still necessary.

The forestry subcommittee of the Idaho Carbon Sequestration Advisory Committee (Kummet et al. 2003) felt the ten items above were a starting point for facilitating the emerging market for carbon credit payments to providers of forestry offset projects. These ideas have been reevaluated at regular intervals and adjusted to meet new considerations as they develop, and that should continue. The subcommittee felt in 2003 that there was a need for state and private cooperation to develop Idaho's forests to their highest sustainable financial and environmental potential (Kummet et al. 2003), and that need continues today.

Furthermore, regarding the lion's share of Idaho's forests that are on National Forest System lands, renewed efforts should be undertaken along with other western States to improve the deteriorating condition of these lands. Idaho cannot do this alone, and should not because it is a West-wide problem. Idaho still has an infrastructure that can do the work needed in the woods (O'Laughlin 2009), and modern efficient mills that can turn timber into useful consumer products. Earlier efforts by the state of Idaho to deal with the gridlocked decision process on national forests have been fruitless (see IDL 2005). Today removals of hazardous fuels and marketable timber products from Idaho's national forests are at the lowest level since 1947 (O'Laughlin 2007). Reducing mortality and improving growth in national forests would enhance their ability to capture more carbon for storage not only on-site, but also off-site in forest products carbon pools. This would also provide a source of renewable energy and improve conditions in rural communities as well as nearby forests. 


\section{B-6. REFERENCES}

Bonnicksen, T.M. 2008. The Forest Carbon and Emissions Model (FCEM): Overview and Technical Information. FCEM Report 1, The Forest Foundation, Auburn, California. 28 p. Online at http://www.calforestfoundation.org/pdf/FCEM.pdf

CCS. 2008. Idaho Greenhouse Gas Inventory and Reference Case Projections, 1990-2020. Center for Climate Strategies for the Idaho Dept. of Environmental Quality, Boise, ID. 97 p. Online at http://www.deq.idaho.gov/air/prog issues/climate change/pdfs/ghg inventory idaho sp08.pdf

CCX. 2009. "Forestry Carbon Emission Offsets." Chicago Climate Exchange, Chicago, IL. Online at http://www.chicagoclimatex.com/content.jsf?id=242

EPA. 2005. Emission Facts: Greenhouse Gas Emissions from a Typical Passenger Vehicle. EPA420-F-05-004, U.S. Environmental Protection Agency. 6 p. Online at http://epa.gov/OMS/climate/420f05004.pdf

EPA. 2009. Inventory of U.S. Greenhouse Gas Emissions and Sinks, 1990-2007. "Table 7-8. Forest area (1000 ha) and C stocks (Tg C) in forest and harvested wood pools." P. 7-16, U.S. Environmental Protection Agency, online at http://www.epa.gov/climatechange/emissions/usinventoryreport.html

Hamilton, K., Sjardin, S,. Shapiro, A., and Marcello, T,. (2009) "Fortifying the Foundation: State of the Voluntary Carbon Markets 2009". Ecosystem Market Place Report.

Kummet, B., Livingston, L. \& McKetta, C. 2003. "Carbon Sequestration Opportunities in Idaho Forests." In, Ferguson, D.F., Carbon Sequestration on Idaho Agriculture and Forest Lands. Idaho Soil Conservation Commission, Boise, ID. P. 13-8 to 13-30. Online at http://www.scc.state.id.us/PDF/Carbon Sequestration/IDAHOSEQUESTRATIONREPORT.pdf

IDL. 2005. "Federal Lands Task Force," especially reintroduction of Clearwater Basin Pilot Project House Bill 835 in 2003 by Rep. C.L. "Butch" Otter. Idaho Dept. of Lands, Boise, ID. Online at http://www.idl.idaho.gov/LandBoard/fltf.htm (accessed June 29, 2009).

IPCC. 2003. Good Practice Guidance for Land Use, Land-Use Change and Forestry. Intergovernmental Panel on Climate Change. Chapter pagination. Online at http://www.ipccnggip.iges.or.jp/public/gpglulucf/gpglulucf.html

O'Laughlin, J. 2007. Timber Harvests and Receipts from National Forest System Lands in Idaho. Issue Brief No. 10, Policy Analysis Group, College of Natural Resources, University of Idaho, Moscow, ID. 13 pp. Online at http://www.cnrhome.uidaho.edu/default.aspx?pid=102907

O’Laughlin, J. 2008. Carbon Sequestration Strategies in the Forest Sector. Issue Brief No. 11, Policy Analysis Group, College of Natural Resources, University of Idaho, Moscow, ID. 17 pp. Online at http://www.cnrhome.uidaho.edu/default.aspx?pid=106665

O'Laughlin, J. 2009. "High forest mortality and low timber removal rates in the Western states promise hazardous fuel accumulations and big fires." Fact Sheet No. 4, Policy Analysis Group, College of Natural Resources, University of Idaho, Moscow, ID. 2 p. Online at http://www.cnrhome.uidaho.edu/default.aspx?pid=113086

O’Laughlin, J. \& Mahoney, R. 2008a. "Forests and carbon.” Woodland Notes 19(2), University of Idaho Extension, online at http://www.cnr.uidaho.edu/extforest/Vol. 19, No. 2.htm\#Forests and_Carbon

O’Laughlin, J. \& Mahoney, R. 2008b. "Payments for forest carbon sequestration." Woodland Notes 20(1), Univ. of Idaho Extension, online at http://www.cnr.uidaho.edu/extforest/Vol. 20 No. 1.pdf

Sampson, N. 2002. Monitoring and Measuring Wood Carbon. The Sampson Group, Inc., Arlington, VA. 3 p. Online at http://www.sampsongroup.com/Papers/Monitoring and Measuring Wood Carbon.pdf 
SAF. 2008. Forest Management Solutions for Mitigating Climate Change in the United States. Climate Change Task Force Report, Society of American Foresters. Journal of Forestry (April/May 2008) 106(4): 115-173. Online at http://www.safnet.org/jof_cetf.pdf

Schoene, D. 2002. "Assessing and reporting forest carbon stock changes: a concerted effort?" Unasy/va 210(53): 76-81.

Smith, J.E., Heath, L.S. \& Nichols, M.C. U.S. Forest Carbon Calculation Tool [CCT]: Forest-Land Carbon Stocks and Net Annual Stock Change. General Technical Report NRS-13, U.S. Dept. of Agriculture, Forest Service, Newton Square, PA. 28 p. + downloadable software. Online at http://www.treesearch.fs.fed.us/pubs/12394

Smith, W.B., Miles, P.D., Perry, C.H. \& Pugh, S.A. 2009. Forest Resources of the United States, 2007. General Technical Report WO-78, U.S. Department of Agriculture, Forest Service, Washington DC. In press, data tables online at http://fia.fs.fed.us/program-features/rpa/docs/2007 RPA_TABLES WO-GTR-78.xls (accessed 16 April 2009).

USDA. 2008. U.S. Agriculture and Forestry Greenhouse Gas Inventory: 1990-2005. Technical Bulletin No. 1921, Global Change Program Office, Office of the Chief Economist, U.S. Department of Agriculture, Washington DC. 161 p. Online at http://www.usda.gov/oce/global_change/AFGGInventory1990_2005.htm (accessed 16 April 2009).

Wiedinmyer, C. \& Neff, J.C. 2007. "Estimates of $\mathrm{CO}_{2}$ from fires in the United States: implications for carbon management." Carbon Balance and Management 2: 10. 12 p. Open access document online at http://www.cbmjournal.com/content/pdf/1750-0680-2-10.pdf

Wilson, M.J. \& Van Hooser, D.D. 1993. Forest Statistics for Land Outside National Forests in Northern Idaho, 1991. Resource Bulletin INT-RB-80, U.S. Dept. of Agriculture, Forest Service, Ogden, UT.

Woodbury, P.B., Smith, J.E. \& Heath, L.S. 2007. "Carbon sequestration in the U.S. forest sector from 1990 to 2010.” Forest Ecology and Management 241: 14-27. 